\title{
STUDIES ON THE RETURNS TO EDUCATION IN GERMANY
}

Dissertation

zur Erlangung des wirtschaftswissenschaftlichen Doktorgrades der Wirtschaftswissenschaftlichen Fakultät der Georg-August-Universität Göttingen

\author{
vorgelegt von \\ M.A. Economics Anja Gelzer \\ aus Wismar
}

Göttingen, 2012 
Erstgutachter: Prof. Dr. Kilian Bizer

Zweitgutachter: Prof. Ingo Geishecker, PhD

Tag der mündlichen Prüfung: 19.12.2011 
Die ersten Ideen zu dieser Dissertation sowie ihre analytische Basis sind im Rahmen des Projektes „Volkswirtschaftliche Nutzen und Kosten des Handwerkskammersystems“, während meiner Zeit am Volkswirtschaftlichen Institut für Mittelstand und Handwerk an der Universität Göttingen (ifh Göttingen), entstanden.

Viele, mir wichtige Menschen, haben meine Dissertations-Phase begleitet. Einigen von Ihnen möchte ich an dieser Stelle meinen Dank aussprechen.

Mein besonderer Dank gilt meinem Doktorvater, Prof. Dr. Kilian Bizer, für seine mentale Unterstützung und sein uneingeschränktes Vertrauen in meine Fähigkeit, die Dissertation auch als Externe und mit Kind erfolgreich abzuschließen.

Herrn Prof. Ingo Geishecker, $\mathrm{PhD}$, danke ich recht herzlich für die Übernahme des Zweitgutachtens und wertvolle, fachliche Hinweise und Anmerkungen, die insbesondere die empirischen Analysen in den Beiträgen 2 und 3 geprägt haben.

Frau Prof. Dr. Susan Seeber möchte ich für die Zusage als Drittprüferin danken. Ihre Perspektive und Expertise als Wirtschaftspädagogin hat meine Disputation sehr bereichert.

Frau Dr. Katarzyna Haverkamp danke ich für das Korrekturlesen der Beiträge, wertvolle inhaltliche Hinweise und zahlreiche Telefonate sowie persönliche Gespräche, die meine Motivation stets positiv beeinflusst und deshalb wesentlich zum Gelingen dieser Arbeit beigetragen haben.

Vom Team des ifh Göttingen möchte ich insbesondere Dr. Klaus Müller danken, der mein Interesse für handwerksspezifische Themen geweckt und mein besonderes Interesse für berufsbildungsspezifische Forschungsansätze stets unterstützt hat.

Meinen Eltern, Gudrun und Jürgen Sölter, verdanke ich das Privileg des Studierens und damit auch die Möglichkeit zur Promotion. Ohne ihre bedingungslose, motivierende und kontinuierliche finanzielle Unterstützung hätte ich diesen Weg nicht beschreiten können.

Kathi Sölter danke ich für ihren unerlässlichen schwesterlichen Beistand, die Ermöglichung wichtiger Denkpausen und privater Momente neben der Promotion.

Mein Mann, Stefan Gelzer, hat auch die dunkelsten Momente der Dissertationsphase mit mir gemeinsam durchgestanden und mich stets mit viel Einfühlungsvermögen und Humor auf die Zielgerade zurückbegleitet. Er hat mir Freiräume an Wochenenden verschafft und mich beharrlich darauf verwiesen, dass ich „noch nie so weit war“. Danke dafür.

Zuletzt möchte ich meiner Tochter Klara danken. Ihre Geburt hat mein Leben und meine Perspektive auf die Dinge verändert. Ihre Existenz hat mich Gelassenheit und Pragmatismus, Entscheidungswillen und Fokussierung gelehrt. Sie hat (unwissentlich) einen erheblichen Beitrag zum erfolgreichen Abschluss dieser Dissertation geleistet. Ihr ist diese Arbeit gewidmet. 


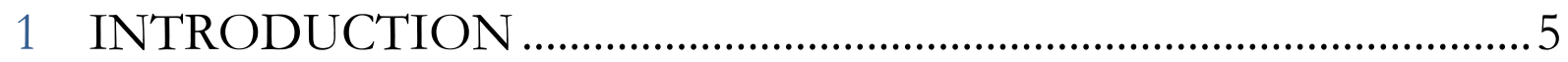

2 HETEROGENEOUS RETURNS TO VOCATIONAL QUALIFICATIONS IN GERMANY 14

3 RETURNS TO SCHOOL AND POST-SCHOOL QUALIFICATIONS IN GERMANY ACCOUNTING FOR FAMILY BACKGROUND AND COGNITIVE ABILITY BIAS 32

4 ECONOMIC RETURNS TO POST-APPRENTICESHIP EDUCATION IN GERMANY -

A FIXED EFFECTS APPROACH …...................................................66

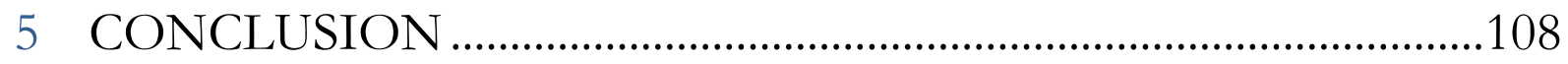




\section{INTRODUCTION}

\section{Motivation}

This thesis is particularly motivated by my personal interest in education economics, the distribution of educational opportunities in the German population, their determinants, individuals' actual educational outcomes and their impact on labor market outcomes, in particular labor income. These topics first sparked my interest when the Institute for Small Business Economics in Göttingen, my employer at the time, was assigned a project on the benefits and costs of the German association of craft chambers ${ }^{1}$. Besides conceptualizing the theoretical framework the most challenging task in the project was for me to evaluate the association's contribution to the systems of dual apprenticeships and further vocational education. In order to evaluate the economic benefits I used the wage equation framework and estimated the returns to craft apprenticeships and craft-specific further vocational education.

Based on this experience I started to dig deeper. Despite the abundance of literature in the field, I soon discovered that some interesting research potential was yet to be exploited. In particular, when screening the literature with applications to German data on the one hand and studies concerned with the characteristics and structure of the education system on the other hand, two sets of observations struck me most. First, German applications seldom truly reflect the structure of educational programs and therefore insufficiently account for the considerable heterogeneity in qualifications provided by the German education system, even at equivalent levels of education. Secondly, discussions on the determinants of educational outcomes and their methodological impact are incorporated only marginally in the returns analyses, as are aggregate movements in the education system and its subsystems as well as educational policy issues.

More specifically, from a methodological point of view many studies use the conventional yearsof-schooling approach, i.e. they estimate the return to an additional year of education. However, the German school system is a three-tiered system and the return to education should differ according to the school track individuals were streamed into. Therefore, a qualification-based approach better reflects the structure of the German educational system. The studies which actually use a qualification-based approach often employ rather heterogeneous specifications of their education variables. Moreover, these tend to represent rather low levels of disaggregation. Evidently, this choice is only partially due to data restrictions. Finally, many German applications do not (sufficiently) account for the endogeneity of education. The direct impact of family

\footnotetext{
${ }^{1}$ Bizer, K.; Haverkamp, K. et al. (2009), Volkswirtschaftliche Nutzen und Kosten des Handwerkskammersystems, Duncker \& Humblot, Berlin.
} 
background has so far been completely neglected. In addition, cognitive ability has been controlled for only in a years-of-schooling setting.

With regard to the heterogeneity of (equivalent) qualifications, in particular within the apprenticeship system, it appears that over time this heterogeneity has tended to increase due to structural changes within educational programs which have been caused by aggregate changes in the economy. Supposedly, the returns to qualifications are also driven by such changes. Moreover, the return to a specific qualification represents some quality indicator with respect to the demand of the labor market skills this very qualification is providing. In addition, the returns to specific qualifications may serve as indicators for whether changes in educational policy are well targeted. Surprisingly, in the literature on the returns to education few references are made with respect to how educational programs are affected by economic change or educational policy, and how this may be reflected in the returns to qualifications.

Given these more general observations, the features of the German education system and associated structural developments I considered most interesting and thus worthwhile integrating into my analyses of the returns to qualifications in Germany were the streaming nature of the educational system and the exceptionality as well as heterogeneity of the dual system of apprenticeship training. As to the first, children are streamed into secondary school tracks very early, at the age of ten on average. Moreover, parental background is an important determinant of children's school and post-school educational outcomes in Germany. Given this influence and the fact that secondary school and post-school educational outcomes are interrelated, it seems that children's future labor market potential is "fixed" rather early in their lives. This suggested both a separation of school and post-school qualifications and the integration of parental background indicators into the analysis of the returns to qualifications.

Secondly, the dual system's exceptionality stems from its quantitative importance and its organizational structure. Firms as well as the chamber organizations are directly participating in the educational process and thus have a direct and large responsibility in providing the economy with skilled labor. As the largest provider of post-school qualifications in Germany, the system offers initial training in about 350 occupations, six training sectors and attracts youth with very different kinds of schooling background. These facts reflect the dual system's substantial heterogeneity which, over time, seems to have increased. Moreover, its functionality is not undisputed in academia. Recent critique relates to the considerable structural changes the system has undergone during the last decades, mostly the considerable decline in traditional craft and industry apprenticeships which could not be compensated by the increase in apprenticeships in commercial, service-related and IT occupations. As a consequence, the system's overall absorptive capacity was adversely affected, in particular with regard to lower level school leavers. 
Nonetheless, the "craft" sector remains the second largest provider of apprenticeships. However, post-initial investments in further education at the vocational level have continuously declined in craft occupations, as have positions equivalent to this level of qualification in the manufacturing industry. In contrast, post-apprenticeship investments at the academic level seem to have increased. Still, recent policy initiative targets post-initial investments both at the vocational and academic level. These developments called for a more in-depth analysis of the apprenticeship system, apprenticeship-specific returns to education and an evaluation of post-apprenticeship investments in education both at the vocational and academic levels.

Therefore, an evaluation of the returns to qualifications, which does neither exhibit an adequate level of disaggregation of qualifications nor is taken out of context, is not suitable for policy recommendations. Against the background of these observations this thesis was developed and written. It provides three contributions to the field of the economics and econometrics of education. All papers are applications to German data and are based on data from the German Socio-Economic Panel (SOEP). While the first paper is a more introductory paper, the second and third papers are much more comprehensive, both with regard to content and methodologically, and thus represent important extensions to the first. A brief outline of the papers and their most important findings is presented in the following paragraphs.

\section{Thesis outline}

The first paper provides an introduction to the field, with some focus on the dual system. Its most important contribution is to provide higher levels of disaggregation of initial and further vocational qualifications than are usually specified. Starting point is the observation that the German economy's competiveness strongly depends upon the quality of its human capital. Not only does this fact put tremendous pressure on the functionality of the economy's education system, it also supposedly increases the competition between educational subsystems. Evidence of structural changes within the education system compares the development of the apprenticeship system relative to other subsystems. This leads to a variety of research questions the empirical analysis attempts to answer. How are the returns to qualifications distributed over time? Is there a trend toward rewarding specific educational certificates more strongly than others? Are there any differences in the returns to post-school qualifications conditional on the type of secondary school completed? Do the returns to dual apprenticeships and full-time vocational schooling differ? Do the returns to apprenticeships differ depending on whether the training was provided in the training sectors "craft" or "industry \& commerce"?

Section 2 briefly summarizes the key elements of the human capital theory and its association with investments in education. Implications are derived for the apprenticeship system and the 
agents involved in the training. Again, the exceptional status of the apprenticeship system is stressed with regard to the involvement of firms and the chamber organizations and its impact on the cost and benefit components of investments in apprenticeship education. A summary of these benefits and costs is then provided. It shows that the economic evaluation of a specific human capital investment is complex and partially infeasible given the presence of non-pecuniary benefits and costs. Moreover, estimating the private return to such an investment represents no more than a fraction of a comprehensive evaluation.

Section 3 introduces the wage equation framework and very briefly reviews the literature. Issues related to the specification of the dependent variable as well as the education and work experience related covariates are discussed. Moreover, the interpretation of the return estimate in a years-of-schooling setting is compared to that in a qualification-based approach. Furthermore, the difficulty of recovering the "true" rate of return is discussed. There are several potential biases such as ability and family background bias, measurement error bias or the bias arising from the selection into employment. They all affect the return estimates. Overall, the bias arising from differences in individual ability has received the greatest attention in the literature, because the correlation between ability and education is evidently strong and individual ability is often unobservable to the researcher. There are several ways to handle these biases. One rests on the assumption that in the presence of all or at least three of these biases, they tend to offset each other. Therefore, conventional OLS produces returns to education which are reasonably close to the true returns. The empirical analysis follows this assumption.

Section 4 provides the estimation results and a discussion. Four specifications are estimated which provide different types and levels of disaggregation of vocational qualifications. The baseline model 1 uses a conventional specification of the highest level of post-school qualifications. It differentiates initial vocational and further vocational education as well as academic education, all relative to no post-school qualification. Specification 1a further disaggregates initial and further vocational qualifications according to the type of secondary schooling completed, while specification 2 provides a separation of the two basic types of initial vocational education, namely apprenticeships and full-time vocational schooling. Finally, model 3 attempts to further differentiate dual apprenticeships and further vocational training according to whether the training was taken in a craft-specific occupation or not. Four different cross-sections of the SOEP data are estimated for each specification to analyze the return estimates over time. The higher levels of disaggregation in the education variables reveal the heterogeneity in the returns to vocational qualifications. The differences in these returns are most pronounced if a disaggregation is conducted with respect to the type of school leaving certificate. 
Section 5 summarizes the results and concludes that some qualification-specific return estimates seem to reflect the aggregate movements in the underlying educational subsystems.

The second paper is an important extension to the first in that it completely separates school and post-school qualifications and further disaggregates education at the academic level. The necessity of disaggregating school and post-school qualifications is derived from the track nature of the German educational system and resulting path dependencies in individuals' school and post-school educational outcomes. Moreover, the paper comprehensively accounts for the endogeneity of education based on observables. Three measures of cognitive ability as well as various indicators which control for differences in family background are jointly employed in the estimations. The strong correlation between family background and children's education is a particular feature of the German educational system and thus requires integration into the returns analysis. Furthermore, the association between individual ability and educational attainment is well known. This paper is the first German application to jointly account for differences in both family background and cognitive ability.

Section 2 provides some more detailed institutional background information on the German educational system. The analysis focuses on school qualifications and the system of vocational education. The latter provides a variety of post-school qualifications. With one exception these qualifications are certification-based. However, they differ with respect to the institutions providing them and the level of qualification. It is stressed that the choice of post-school qualifications is conditioned by the type of school leaving certificate obtained. This range of choice is greatest for those with an Abitur most of which opt for academic education. In contrast, lower and intermediate secondary school leavers are more or less restricted to initial vocational education. Thus, school and post-school qualifications are strongly intertwined. Consequently, labor market outcomes are pre-determined by schooling outcomes. Since school performance is a function of both ability and family background, these may as well affect individuals' labor market potential.

Section 3 comprehensively reviews the literature. The main focus is on contributions which use a qualification-based approach. First, issues related to the specification of the education variables are discussed. It is shown that the education categories in the German studies, though based on the same data set (SOEP), are quite heterogeneous and only partly reflect the formal structure of the German educational system. Moreover, with one exception they do not separate school and post-school qualifications. Secondly, a description of the handling of the endogeneity of education in the different studies is given. The UK studies stress the importance of directly 
controlling for differences in (early) ability and family background. However, most German studies account for neither of the two.

Section 4 starts with a description of the data set and briefly discusses the problems related to the "choice" of sample. The main problems encountered were that the cognitive ability test results are restricted to the year 2006 and are available for a subsample of respondents only. Similarly, school grades and the family background indicators represent one-time information. This information was not jointly available in 2006. Also, item non-response was an issue for all cognitive ability and family background variables. Therefore, all available information had to be pooled across ten cross-sections and missing information was explicitly controlled for.

Furthermore, the basic empirical model is presented. In addition, the exact specification of the education-related variables as well as the cognitive ability and family background variables is described. Then descriptive statistics for these variables are presented. It is shown that there is indeed a strong association between the type of school qualification and the level/type of postschool qualification. The section also discusses the potential impact of the measures of cognitive ability and family background on both qualifications and wages. It is concluded that their direct integration into the wage equation is justified. Finally, it is suggested that since the empirical model appropriately controls for cognitive ability, grades and family background, it is sufficiently and well specified to produce unbiased estimates of the returns to qualifications. Therefore, the model is estimated by pooled OLS.

The estimation results are summarized in section 5. The baseline model only controls for differences in post-school qualifications. The second specification additionally controls for differences in cognitive ability and family background. It can be shown that the coefficients are indeed biased upwards in the baseline model compared to model 2. The third specification includes school and post-school qualifications, while the fourth model is the full specification in which account is taken of differences in school qualifications, cognitive ability and family background. The returns to school qualifications are sizeable but very heterogeneous. Interestingly, the returns to post-school qualifications react more strongly to the inclusion of the variables indicating secondary school type than to the inclusion of the sets of cognitive ability and family background measures. Moreover, returns to higher level school qualifications exceed the returns to basic post-school qualifications.

The section provides additional evidence on how the returns to school and post-school qualifications differ by cognitive ability. Both joint linear effects and non-linearities are analyzed. School grades only affect the premiums of high school graduates. The returns to some school and post-school qualifications are affected by the two measures of cognitive ability, however mostly in an unexpected direction. 
Section 6 summarizes the most important findings. It is concluded that controlling for school qualifications is particularly revealing, since the returns to basic vocational post-school qualifications are well below the returns to school qualifications.

Similar to the first paper, the third paper deals with the heterogeneity in apprenticeships and labor market outcomes. However, this time the analysis focuses on how this heterogeneity affects the associated further education options. These are then evaluated in terms of their economic return. Based on the assumption that life-long learning will affect not only continuing training, but also formal attainment, and given the observation that the potential for further attainment is particularly high among individuals who completed initial vocational education (apprenticeships), it is suggested that sequences of post-school qualifications may become increasingly important. Though recent policy measures promote post-initial further education both at the vocational and academic levels, the occupation/sector specific evidence is mixed as regards the development of these types of further investments. How is this reflected in the corresponding return estimates? The paper provides fixed-effects estimates of the returns to post-apprenticeship qualifications at the vocational and academic levels.

Section 2 examines the role of sequences of post-school qualifications in Germany. First, descriptive evidence is provided, based on data from the 2005/2006 Qualification and Career Survey. It is shown that such sequences are relatively frequent. However, they do not necessarily combine initial and higher level qualifications. Still, combinations of initial vocational and further education are the most frequent. Unexpectedly, post-apprenticeship investments in academic education are slightly more frequent than investments in further vocational qualifications.

Further occupation and sector specific evidence indicates why this may be the case. In fact, traditional craft and industry apprenticeships have been adversely affected by the economy's structural change and the shift in preferences of youth away from blue collar to white collar jobs. In contrast, the role of apprenticeships in commercial, service-related and IT occupations is increasing. Evidence from the craft and banking sectors shows that further education options are moving accordingly. Overall, purely vocational paths in traditional occupations are on a decline, while mixed vocational and academic paths in modern occupations are on a rise.

The empirical literature is reviewed in section 3. It is stated that most of the returns literature uses a year-of-schooling approach and treats education as a time-invariant variable. More importantly, though longitudinal analyses would be particularly suitable given the endogeneity of education, cross-sectional analyses as well as instrumental variable methods are preponderant. Even in the presence of panel data, education is almost exclusively treated as a time-constant variable which makes it impossible to identify the returns to education in a fixed-effects context. German 
applications based on longitudinal data either do not use fixed-effects methods or analyze the returns to continuous training, not formal attainment. Thus, in providing fixed-effects estimates of the returns to post-apprenticeship qualifications in Germany, the analysis is both novel and rather unconventional.

Section 4 starts with an introduction of the data set and discusses sampling as well as weighting issues. The latter mostly concerns the difficulties associated with the construction of the longitudinal weights, in particular the handling of sample design-based drop outs. Furthermore, the empirical model is presented and a description is given of how the most important variables were constructed. Another subsection discusses issues relevant to the estimation procedure. More specifically, fixed-effects estimation is justified in the presence of individual-specific unobserved effects which are correlated with the regressors. An overidentification test which is used to test for this correlation is introduced and reveals that the regressors are in fact endogenous. Some of the return estimates may be less well identified though, because the variation in the corresponding education variables is rather low over time.

The section concludes with descriptive evidence of the current job (ISCO-88 codes) individuals held at the time they completed their higher level post-school qualification. Overall, the distribution of the job codes by the type of the second post-school qualification confirms the picture provided in section 2. However, mixed vocational and academic education is also important in high-skill technical occupations.

Section 5 provides the estimation results by sample, region and sex. Except for West German males, there is no significant return to further vocational education, while the returns to postapprenticeship university education are significantly positive and sizeable in most specifications. Combining further vocational and academic education is associated with a significant wage penalty in the majority of specifications.

The final section concludes that though politically and socially desired the public promotion of further vocational education options, most notably the Master craftsperson qualification, seems less justified on economic grounds since the return estimates show that the investment is not profitable.

\section{Contribution}

This thesis contributes to the fields of the economics and econometrics of education in several respects. By establishing a stronger link between the empirical evaluation of specific qualifications and their underlying educational subsystems, it delivers new insights into the association between formal qualifications and individual labor market outcomes in Germany. 
More specifically, the thesis delivers substantial background information on the structure and specific features of the educational system and incorporates these into the analysis of the returns to qualifications. Furthermore, it is described how specific educational subsystems are affected by the challenges posed by technological and structural change in the economy and how these changes might translate into the returns associated with corresponding qualifications.

Such content-or context-based analysis not only allows a more background-oriented interpretation of the return estimates, but also makes new demands on the methods of evaluating German qualifications. As concerns the latter, the thesis advocates both a departure from the years-of-schooling approach and higher levels of disaggregation of the education variables. Where feasible, the integration of school qualifications is particularly insightful. Further methodological contributions are the comprehensive analysis of and control for family background and cognitive ability, i.e. observable heterogeneity (paper 2). Moreover, paper 3 provides fixed-effects estimates of the returns to two types/levels of post-apprenticeship qualifications and thus accounts for unobserved individual heterogeneity.

Finally, in targeting specific features and recent developments of the German educational system and in taking up recent educational policy and reform initiatives, this work furthers the academic and political discussions on the effective provision of education in an increasingly older and unequal society whose future economic competiveness is mainly driven by the quality of its human capital. Related key issues touched upon raise questions about the equality of opportunity in the access to educational programs and resulting labor market outcomes, in particular labor income, and the general degree of permeability of the German education system, especially the equivalence of as well as dichotomy between vocational and academic qualifications. We can neither afford to let education potentials go unexploited nor to spend resources on human capital investments which are not economically and/or socially beneficial. 


\section{HETEROGENEOUS RETURNS TO VOCATIONAL QUALIFICATIONS IN GERMANY ${ }^{2}$}

\section{Abstract}

Based on data from the German Socio-economic Panel (SOEP) and a simple OLS approach, several specifications of education variables are used to estimate the returns to various qualifications in Germany. Specific attention is paid to dual apprenticeships and the question of how recent developments in the underlying educational subsystem relative to other subsystems may be reflected in corresponding return estimates. Qualification-specific wage premiums are estimated conditional on secondary school type, with respect to two types of initial vocational education and with respect to whether vocational training is craft-specific or not. Overall, some of the coefficients seem to reflect the aggregate movements in the underlying educational subsystems.

\footnotetext{
2 This paper draws on Sölter \& Bizer (2010).
} 


\section{INTRODUCTION}

According to the German Council of Economic Experts the future competitiveness of the German economy relies on the quantity and - more importantly - the quality of its human capital. This conviction stems from both the economy's scarcity in natural resources and the challenges posed by demographic and technological change (Sachverständigenrat zur Begutachtung der gesamtwirtschaftlichen Entwicklung, 2004). If human capital is the key to sustained economic growth and prosperity, the German educational system as the main provider of human capital has a large responsibility in coping with these challenges. Given the complexity of the educational system with respect to the number of institutions and agents involved, as well as the variety of qualifications provided, this is not any easy task.

This paper focuses on the system of vocational education, in particular the dual system of apprenticeship training. Further vocational as well as academic qualifications serve as a comparison. The system of vocational education provides post-school qualifications. Conditional on their successful completion these post-school qualifications lead to nationally acknowledged vocational or academic certificates. Initial vocational education (including apprenticeships) as well as academic programs can be entered directly upon leaving school, while further vocational education is conditional on the prior completion of initial vocational training.

The dual system of apprenticeship training is a very specific subsystem of the system of initial vocational education. Other pillars are the system of vocational schooling and the so-called transitory system (“Übergangssystem”). The system of vocational schooling provides full-time education and offers courses in which schooling credentials, partial vocational qualifications as well as full-qualifying vocational certificates can be acquired (Ruf, 2008). In contrast, measures in the transitory system are of a preparatory and qualifying nature, i.e. acknowledged vocational certificates cannot be attained.

The distinctiveness of the dual system lies in the number and types of agents involved in the educational process. In particular, the direct participation of firms is relatively unique to the dual system. In fact, to a large part the training takes place on site. In contrast to other educational subsystems, the apprenticeship system is subject to corporatist organization and control at the state and federal levels. According to Finegold \& Wagner (2002, p. 669), the German apprenticeship system "represents perhaps the clearest manifestation of corporatism in the skills field". Overall, the dual system of apprenticeship training represents the educational subsystem in which the business economy has a far reaching responsibility in supplying the economy with skilled labor. After all the dual system hinges on the voluntary supply of apprenticeship places by 
German firms. At the same time, the system's performance depends upon an adequate pool of potential apprentices.

As technological change predominantly affects the structure of labor demand, the dual system and the other educational subsystems equally have to cope with the resulting pressure to adjust accordingly. Moreover, changing labor demand also increases the competition between educational systems. Evidently, these developments have affected the apprenticeship system more strongly than other educational subsystems, since it has lost ground in quantitative terms relative to them. More specifically, in absolute numbers, full-time vocational schooling is gaining ground relative to the dual system, i.e. horizontally (Autorengruppe Bildungsberichterstattung, 2010). Relatively, the dual system loses both to higher level (universities) and lower level institutions (transitory system) (Baethge et al., 2007).

Even internally the apprenticeship system is facing continuous structural change, with some shift in the overall importance of the two dominant training sectors, away from the craft sector toward industry \& commerce. Furthermore, the dual system must continuously cope with its strong procyclicality, i.e. the strong dependence of the supply of apprenticeship places and firms' economic situation. Finally, there is an ongoing discussion about the system's declining absorptive capacity of youth with no school leaving certificate or secondary general schooling. This development is particularly worrying since for these groups of individuals the dual system has long been the classic path towards paid employment. For these individuals there are no real alternatives to entering the labor market (Baethge et al., 2007). Overall, the criticism with respect to the performance of the dual system in academia and increasing fears with regard to imminent skill shortages prevailing in the public debate are standing vis-à-vis.

In the light of these observations, this paper evaluates the returns to various qualifications in Germany with a specific focus on the returns to apprenticeships. More specifically, the paper analyzes in how far the wage equation framework and the data employed are suitable to analyze the competition between educational programs and subsystems. How are the returns to qualifications distributed over time? Is there a trend toward rewarding specific educational certificates more strongly than others? Are there any differences in the returns to formally equivalent post-school qualifications conditional on the type of secondary school completed? Do the returns to dual apprenticeships and full-time vocational schooling reflect the above mentioned structural changes? Do the returns to dual training differ between the two dominant training sectors?

The remainder of the paper is organized as follows. Section 2 provides a brief account of the human capital theory and its implications for dual apprenticeships. Particular attention is paid to implications derived from cost-return-considerations. The wage equation framework and 
associated problems are discussed in section 3. Section 4 describes the data set, provides the estimation results and a discussion. Section 5 concludes.

\section{HUMAN CAPITAL THEORY AND INVESTMENTS IN EDUCATION}

Since the seminal contributions of Becker (1975), Mincer (1974) and Schultz (1963) the term human capital and the underlying concept have become key elements of economic research and are part of virtually every labor economics textbook. The concept of human capital also heavily contributed to advancing the theory of economic growth.

The term human capital implies that knowledge is some form of capital or asset. Activities which aim at increasing this knowledge thus exhibit characteristics of an investment. If knowledge and skills can be acquired and increased through education, not all ability is innate (e.g. Sachverständigenrat zur Begutachtung der gesamtwirtschaftlichen Entwicklung, 2004; Schultz, 1962). Therefore, an economy's stock of human capital is a function of both the size of its population and a qualitative element. This qualitative or productivity component of economies' human capital has proved to be a decisive explanatory factor of past economic growth and the observed income distribution within economies (Schultz, 1962).

In business economics an investment is defined as today's allocation of financial resources conditional on higher expected return flows in the future (Wöhe, 1996). Similarly, with regard to human capital investments Becker $(1962$, p. 9) states that “(...) activities that influence future real income through the imbedding of resources in people (...) [are] called investing in human capital“. The terms human capital investment and investment in education are frequently used synonymously.

The expectations about the future returns associated with investing in education are closely related to the so-called productivity hypothesis. The productivity hypothesis represents the core of human capital theory (Timmermann, 2005). It states that knowledge acquisition raises individuals' productive efficiency. If individuals earn a wage equal to their marginal productivity, individual productivity and individual wages are associated. If educational attainment (formal qualifications) increases individual productivity, education and labor market success (higher wages through higher education) have to be associated as well. Human capital theory even goes further in assuming a causal relationship between education and earnings, where the causality necessarily runs from the investment in education toward labor market outcomes (Timmermann, 2005). 
Evaluating investments in education is complex, since an analysis of the costs and benefits of any training must involve all agents participating in the educational process. For example, apprenticeship training is not solely a private and social investment. Given the system's specific organizational structure, in particular the participation of firms and chambers, the common distinction of individual as well as social costs and benefits associated with investments in education (e.g. Ammermüller \& Dohmen, 2004; Elliott, 1997) does not sufficiently reflect the structure of the apprenticeship system. Therefore, firm-specific and para-fiscal costs and benefits have to be added.

According to the human capital theory, costs are incurred during apprenticeship training, i.e. the investment phase, whereas the benefits are reaped after the training is completed. These accrue over the whole working life (e.g. Ammermüller \& Dohmen, 2004). Firm-specific investment decisions may also be influenced by potential benefits accruing during training. In such cases, the training costs borne by the firm may be balanced out before the training is even completed. For example, craft firms frequently bear only small or no costs in the training of apprentices which partly explains their comparatively strong commitment in the training of apprentices (Beicht et al., 2004; Franz \& Soskice, 1995; Soskice, 1994). Similarly, apprentices earn a wage which constitutes a benefit realized during the training period, at the same time reducing apprentices' opportunity cost of training.

Furthermore, investments in education may be associated with a risk. It is thus possible that some cost has to be incurred after the investment was made. After all, the assumption of secure and constant (monetary) returns may be corrupted by the respective labor market situation. In addition, the skills acquired may be subject to depreciation. In fact, technological change may have contributed to raising the rate of depreciation of human capital acquired during initial training (Pfeiffer, 1997; Pfeiffer \& Blechinger, 1995), which can be compensated only by individuals' and firms' continuous effort to invest in education to keep up their employability and competitiveness, respectively.

TABLES 1 and 2 provide an overview of the costs and benefits associated with dual apprenticeships. Though the lists are not exhaustive, they clearly show that a comprehensive evaluation of investments in education is a challenging task. Many cost-benefit components are extremely difficult or impossible to measure. Moreover, there is a strong interdependence of financial flows between agents (Hummelsheim \& Timmermann, 1999) of which the two summaries can give but a first impression. 
TABLE 1 COST COMPONENTS OF DUAL APPRENTICESHIPS

\begin{tabular}{|c|c|c|c|}
\hline & \multicolumn{3}{|c|}{ cost type } \\
\hline & & pecuniary & non pecuniary \\
\hline \multirow[t]{3}{*}{$\begin{array}{l}\text { private cost } \\
\text { (Ammermüller \& } \\
\text { Dohmen, 2004; Elliott, } \\
\text { 1997) }\end{array}$} & & $\begin{array}{l}\text { forgone market opportunities } \\
\text { forgone labor earnings in case individual had taken } \\
\text { on a job (reference income equal to that of next } \\
\text { lower level of education, adjusted for the probability } \\
\text { of unemployment of this group plus the apprentice } \\
\text { wage) }\end{array}$ & $\begin{array}{l}\text { psychic cost } \\
\text { learning effort, exam nerves }\end{array}$ \\
\hline & 2. & $\begin{array}{l}\text { direct cost } \\
\text { fees, study material }\end{array}$ & $\begin{array}{l}\text { forgone non-market opportunities } \\
\text { leisure time and corresponding activities possible if } \\
\text { time had been spent differently }\end{array}$ \\
\hline & 3. & $\begin{array}{l}\text { indirect cost } \\
\text { additional housing or travel cost, cost of living }\end{array}$ & \\
\hline $\begin{array}{l}\text { firm-specific cost } \\
\text { (Beicht et al., 2004; } \\
\text { Niederalt, 2004) }\end{array}$ & 3. & $\begin{array}{l}\text { personnel cost of apprentices } \\
\text { apprentice wage, statutory benefits, fringe benefits, } \\
\text { bargained benefits } \\
\text { personnel cost of trainers } \\
\text { full-time, part-time, external } \\
\text { non personnel cost } \\
\text { workplace, apprenticeship workshop, in-house } \\
\text { training } \\
\text { other cost } \\
\text { teaching material, chamberfees, clothing, external } \\
\text { training, administrative costs }\end{array}$ & \\
\hline $\begin{array}{l}\text { chamber cost } \\
\text { (Bizer et al., 2009) }\end{array}$ & 1. & $\begin{array}{l}\text { supervision and administration of } \\
\text { apprenticeships } \\
\text { registry, counseling, educational policy activities } \\
\text { extracurricular, outplant training } \\
\text { courses, participants } \\
\text { examinations } \\
\text { intermediate, final examinations before chamber } \\
\text { jury }\end{array}$ & \\
\hline $\begin{array}{l}\text { public cost } \\
\text { (Ammermüller \& } \\
\text { Dohmen, 2004) }\end{array}$ & 1. & $\begin{array}{l}\text { opportunity costs } \\
\text { forgone tax payments and social security payments } \\
\text { during apprenticeship } \\
\text { direct cost } \\
\text { public educational institutions (public vocational } \\
\text { schools, buildings, personnel, teaching material); } \\
\text { subsidies granted to apprentices and other agents } \\
\text { involved (e.g. chambers) }\end{array}$ & \\
\hline
\end{tabular}

Source: own compilation. 


\begin{tabular}{|c|c|c|c|}
\hline & & \multicolumn{2}{|c|}{ benefit type } \\
\hline & & pecuniary & non pecuniary \\
\hline \multirow[t]{2}{*}{$\begin{array}{l}\text { private benefits } \\
\text { (Ammermüller \& } \\
\text { Dohmen, 2004; Elliott, } \\
\text { 1997) }\end{array}$} & 1. & $\begin{array}{l}\text { expected increase in income } \\
\text { return to bigher level of qualification relative to } \\
\text { next lower qualification group }\end{array}$ & $\begin{array}{l}\text { private social benefits } \\
\text { e.g. higher level of decision making efficiency, higher } \\
\text { standard of living, increasing health (increased } \\
\text { awareness), higher satifaction, stronger } \\
\text { participation in social life, positive externalities } \\
\text { (family, environment) }\end{array}$ \\
\hline & 2. & $\begin{array}{l}\text { other benefits } \\
\text { lower unemployment risk, higher level of } \\
\text { employability }\end{array}$ & \\
\hline \multirow[t]{2}{*}{$\begin{array}{l}\text { firm-specific benefits } \\
\text { (Beicht et al., 2004; } \\
\text { Lindner, 1998) }\end{array}$} & 1. & $\begin{array}{l}\text { productive benefits during apprenticeship } \\
\text { equal to personnel cost which otherwise would have } \\
\text { been spent }\end{array}$ & $\begin{array}{l}\text { synergies } \\
\text { general human capital acquired (apprentice) at } \\
\text { vocational school or in chamber training which } \\
\text { might be useful in firm }\end{array}$ \\
\hline & 2. & $\begin{array}{l}\text { productive benefits after apprenticeship is } \\
\text { completed } \\
\text { training or other firm (externality) }\end{array}$ & \\
\hline $\begin{array}{l}\text { chamber benefits } \\
\text { (Bizer et al., 2009) }\end{array}$ & 1. & $\begin{array}{l}\text { fee income } \\
\text { registry, examinations }\end{array}$ & $\begin{array}{l}\text { honorary activities } \\
\text { potential association between level of education and } \\
\text { commitment to bonorary functions }\end{array}$ \\
\hline $\begin{array}{l}\text { public benefits } \\
\text { (Ammermüller \& } \\
\text { Dohmen, 2004) } \\
\end{array}$ & 1. & $\begin{array}{l}\text { direct benefits } \\
\text { bigher level of tax and social security payments }\end{array}$ & \\
\hline \multirow[t]{2}{*}{$\begin{array}{l}\text { social benefits } \\
\text { (Ammermüller \& } \\
\text { Dohmen, 2004) }\end{array}$} & 1. & $\begin{array}{l}\text { static externalities } \\
\text { immediate impact on productivity of machinery and } \\
\text { other persons raising aggregate productivity and } \\
\text { wages }\end{array}$ & $\begin{array}{l}\text { other externalities: social behavior of } \\
\text { citizens } \\
\text { e.g. lower crime rate, higher voter turnout }\end{array}$ \\
\hline & 2. & $\begin{array}{l}\text { dynamic externalities } \\
\text { increase in learning efficiency leading to faster } \\
\text { technical change and economic growth }\end{array}$ & \\
\hline
\end{tabular}

Source: own compilation.

\section{THE WAGE EQUATION FRAMEWORK}

The standard Mincer-type wage equation is based on the seminal work of Mincer (1974). The association between education and wages is the most frequently analyzed subject in empirical economic research (Jochmann \& Pohlmeier, 2004). Comprehensive Handbook of Labor Economics reviews are provided in Willis (1986) and, more recently, in Card (1999). Blundell et al. (2005) provide a more recent survey, with some more references to the British literature. The German literature is reviewed in Flossmann \& Pohlmeier (2006) and Lauer \& Steiner (1999).

In its simplest form, the Mincer-type wage equation analyzes the association between formal education, work experience and earnings. For a cross-section of employed persons this association can formally be stated as follows:

$\log \left(\operatorname{wage}_{i}\right)=\beta_{0}+\beta_{1} \operatorname{educ}_{i}+\beta_{2} \exp _{i}+\beta_{3} \exp _{i}^{2}+\varepsilon_{i}$ 
The dependent variable is the natural logarithm of individuals' earnings. Frequently the gross hourly wage is used in estimations. In contrast, Ammermüller \& Dohmen (2004) recommend employing net hourly wages, since gross wages are not adjusted for taxes and thus represent a mixture of both private and social benefits (taxes are state-specific benefits of education). Net wages on the other hand are influenced by tax exemptions based on marital status, having children etc. The independent variables, whose impact on individual labor earnings is to be estimated, are formal education (educ), mostly measured in years, work experience (exp, metric as well) and work experience squared (assumption of concave income curve over working life). In the literature work experience is either measured directly or approximated by age minus the period of education (schooling and post-school qualification). The error term comprises those effects on the wage which have been deliberately omitted or are not observable.

The coefficient of the formal education variable gives the return to education and can be formally interpreted as the constant per-cent wage increase of an additional year of education: $\% \Delta$ wage $\approx\left(100 * \beta_{1}\right) \Delta e d u c$ (Wooldridge, 2006). If dummy variables are used to represent different levels of education the wage effect has to be calculated slightly differently, \% $\%$ wage $\approx$ $100 *\left(e^{\beta_{1}}-1\right)$. Here the return is then interpreted with respect to some reference level of education. An alternative representation of the effect of education on wages is the following (Flossmann \& Pohlmeier, 2006; Ammermüller \& Dohmen, 2004):

$\frac{\partial \log (\text { wage })}{\partial e d u c}=\beta_{1} \approx \frac{\text { wage }_{t+1}-\text { wage }_{t}}{\text { wage }_{t}} \approx \log (\text { wage })_{\mid e d u c=t+1}-\log (\text { wage })_{\mid e d u c=t}$.

The advantage of multivariate wage regressions relative to other methods of return calculations (e.g. Ammermüller \& Dohmen, 2004; Psacharopulos, 1995) is the estimation of the return to education conditional on other covariates (e.g. gender, economic sector or firm size) which are supposed to affect the wage distribution (Ammermüller \& Dohmen, 2004). Moreover, if a qualification-based approach is used (dummy variables for types/levels of education) instead of the common years-of-schooling approach, it is possible to directly compare the returns to different qualifications compared to some reference level (mostly no formal qualification).

One of the disadvantages of the wage equation framework is that on the cost side it only accounts for private opportunity $\operatorname{costs}^{3}$ (Ammermüller \& Dohmen, 2004; Elliott, 1997). In fact, as the above equations suggest, the return to education is what we additionally earn if some more education is undertaken as compared to what we would have earned if that education had not been undertaken. Additional private costs and, in the case of dual apprenticeships, the costs incurred by the other agents, are not part of the framework (see the previous section). Moreover,

\footnotetext{
${ }^{3}$ Forgone market opportunities (see TABLE 1).
} 
the risk potentially associated with (some) human capital investments, is not considered either (Ammermüller \& Dohmen, 2004).

Besides the abundance of studies which analyze the returns to education, there is no uniform convention regarding the choice of sample, the operationalization of the educational variables or the choice of further covariates. As a consequence, the available studies, even if restricted to a specific country, are difficult to compare. However, the most challenging problem lies in estimating the "true" return to education (Wolter \& Weber, 2005, p. 41), i.e. in establishing a causal relationship between education and earnings (Card, 2001). Estimating the true or causal return to education is particularly important if both costs and benefits of human capital investments are analyzed to evaluate them in terms of their quality or efficiency. In this way, we can compare the overall performance of different educational programs and the institutions providing them.

The main problem we are facing is that individuals are not randomly distributed across educational paths. Educational attainment is a function of individual and a variety of other factors and thus subject to complex decision making processes. This means that education is endogenous and we need to control for the factors which supposedly are correlated with education (and wages) in order to recover an unbiased estimate of the return to education. Unfortunately, if these factors are not observable to the researcher, conventional OLS estimates of the return to education tend to be biased. In this respect, the association between education and individual ability, and resulting potential econometric problems, have gained considerable attention in the literature (see Griliches, 1977, for an early but influential survey). Another potential bias can arise from the association between family background and educational attainment. ${ }^{4}$ In addition, biases can arise from the selection into employment or if education is measured with error (measurement error bias).

Overall, the evidence regarding the magnitude of the potential biases is far from homogeneous. This is not too surprising given the variety of available studies. Moreover, some studies stress that conventional OLS which accounts for neither of the biases just mentioned may produce estimates of the returns to education which are close to the true returns, since the biases tend to offset each other (Dearden et al, 2002; Dearden, 1999). Therefore, in this paper we stick to the conventional method of ordinary least squares to estimate the returns to various qualifications in Germany.

\footnotetext{
${ }^{4}$ In the German literature the term opportunity bias describes the impact of differences in (financial) resources and time preferences on education (cp. Ammermüller \& Dohmen, 2004; Jochmann \& Pohlmeier, 2004). However, we consider this type of bias to be very closely related to what e.g. Blundell et al. (2005), Dearden et al. (2002) and Dearden (1999) call family background bias.
} 


\section{THE PRIVATE RETURNS TO EDUCATION}

We use data from the most recent distribution of the German Socio-economic Panel (SOEPv26) to estimate the returns to education in Germany. The SOEP is a representative longitudinal survey of households and persons living in Germany. The data are provided by the German Institute for Economic Research (DIW) and are available since 1984 (New Länder since 1990). Our estimations refer to four cross-sections (1990, 1995, 2000 and 2005) of full-time working persons in dependent employment. The analysis is restricted to West-Germany.

TABLE 3 SUMMARY OF MODEL SPECIFICATIONS

\begin{tabular}{|c|c|c|c|c|c|}
\hline \multirow[b]{2}{*}{$\begin{array}{l}\text { formal } \\
\text { education }\end{array}$} & Model 1 & \multicolumn{2}{|c|}{ Model 1a } & \multirow{2}{*}{$\begin{array}{c}\text { Model } 2 \\
\text { differentiation of initial } \\
\text { vocational education } \\
\text { qualifications }\end{array}$} & \multirow{2}{*}{$\begin{array}{c}\text { Model } 3 \\
\text { differentiation of dual } \\
\text { apprenticeships according } \\
\text { to training sector }\end{array}$} \\
\hline & $\begin{array}{c}\text { bighest level of post-school } \\
\text { qualification independent } \\
\text { of schooling }\end{array}$ & $\begin{array}{r}\text { highest school qualificat } \\
\text { post-school }\end{array}$ & $\begin{array}{l}\text { on combined with highest } \\
\text { qualification }\end{array}$ & & \\
\hline base group & $\begin{array}{l}\text { no post-school } \\
\text { qualification }\end{array}$ & $\begin{array}{l}\text { no school leaving } \\
\text { certificate }\end{array}$ & $\begin{array}{l}\text { no post-school } \\
\text { qualification or initial } \\
\text { vocational education }\end{array}$ & $\begin{array}{l}\text { no post-school } \\
\text { qualification }\end{array}$ & $\begin{array}{l}\text { no post-school } \\
\text { qualification }\end{array}$ \\
\hline \multirow{3}{*}{1.} & \multirow{3}{*}{$\begin{array}{l}\text { initial vocational } \\
\text { education }\end{array}$} & $\begin{array}{c}\text { lower secondary } \\
\text { schooling }\end{array}$ & \multirow{3}{*}{$\begin{array}{l}\text { plus initial } \\
\text { vocational } \\
\text { education }\end{array}$} & \multirow{2}{*}{$\begin{array}{l}\text { dual system } \\
\text { (apprenticeship } \\
\text { training) }\end{array}$} & crafts sector \\
\hline & & $\begin{array}{c}\text { intermediate } \\
\text { secondary schooling }\end{array}$ & & & $\begin{array}{l}\text { other (industry \& } \\
\text { commerce) }\end{array}$ \\
\hline & & Abitur & & $\begin{array}{l}\text { full-time vocational } \\
\text { schooling }\end{array}$ & $\begin{array}{l}\text { full-time vocational } \\
\text { schooling }\end{array}$ \\
\hline \multirow{3}{*}{2.} & \multirow{3}{*}{$\begin{array}{c}\text { further vocational } \\
\text { education }\end{array}$} & $\begin{array}{c}\text { lower secondary } \\
\text { schooling }\end{array}$ & \multirow{3}{*}{$\begin{array}{l}\text { plus further } \\
\text { vocational } \\
\text { education }\end{array}$} & \multirow{3}{*}{$\begin{array}{c}\text { further } \\
\text { vocational } \\
\text { education }\end{array}$} & \multirow{2}{*}{$\begin{array}{c}\text { craft-specific further } \\
\text { vocational } \\
\text { education }\end{array}$} \\
\hline & & $\begin{array}{c}\text { intermediate } \\
\text { secondary schooling }\end{array}$ & & & \\
\hline & & Abitur & & & $\begin{array}{c}\text { other further } \\
\text { vocational education }\end{array}$ \\
\hline 3. & & & academic education & & \\
\hline
\end{tabular}

Based on the challenges that the educational subsystems are currently facing and the corresponding research questions formulated in the introduction we chose to use several specifications to estimate the returns to human capital investments in Germany (see TABLE 3). Our specifications of the education variables necessitate the use of dummy variables for the different types of qualifications instead of the years-of-schooling approach as in the standard Mincer model. Employing dummy variables is particularly important, since it allows the analysis of potential differences between formally equivalent qualifications within the system of initial vocational education and the returns to vocational qualifications conditional on secondary school type. 
Ordinary least squares estimation of the different specifications allows us to establish an association between specific qualifications and earnings. Though there may be some bias in the return estimates, this bias is assumed to be small.

TABLE 4 OLS ESTIMATION RESULTS OF MODEL 1

\begin{tabular}{|c|c|c|c|c|}
\hline \multicolumn{5}{|c|}{$\begin{array}{l}\text { Model 1 } \\
\text { bighest level of post-school qualification independent of schooling }\end{array}$} \\
\hline \multirow[b]{3}{*}{ further vocational education } & 1990 & 1995 & 2000 & 2005 \\
\hline & $\begin{array}{c}.171 * * * \\
(.020)\end{array}$ & $\begin{array}{c}.124 * * * \\
(.019)\end{array}$ & $\begin{array}{c}.144 * * * \\
(.019)\end{array}$ & $\begin{array}{c}.196^{* * *} \\
(.032)\end{array}$ \\
\hline & $\begin{array}{c}.320 * * * \\
(.0 .29)\end{array}$ & $\begin{array}{c}.252^{* * *} \\
(.036)\end{array}$ & $\begin{array}{c}.312^{* * *} \\
(.025)\end{array}$ & $\begin{array}{c}.302^{* * *} \\
(.037)\end{array}$ \\
\hline academic education & $\begin{array}{c}.587 * * * \\
(.038) \\
\end{array}$ & $\begin{array}{c}.531 * * * \\
(.032) \\
\end{array}$ & $\begin{array}{c}.530 * * * \\
(.026) \\
\end{array}$ & $\begin{array}{c}.538^{* * *} \\
(.039) \\
\end{array}$ \\
\hline $\mathrm{N}$ & 3,165 & 3,005 & 5,110 & 3,720 \\
\hline $\mathrm{R}^{2}$ & 0.357 & 0.343 & 0.342 & 0.345 \\
\hline
\end{tabular}

dependent variable: natural log of real gross hourly wage.

additional covariates: full-time work experience in years and its square, dummies for gender, nationality, economic sector, firm size.

OLS estimation; standard cross-sectional weights provided in the SOEP were employed; robust standard errors in parantheses; significance levels: * $10 \%, * * 5 \%$, *** $1 \%$.

Source: SOEP (2010), own calculations.

Model 1 is the base line specification. Here the returns to the highest post-school qualification are estimated relative to having no post-school qualification, independent of schooling (see TABLE 4). The coefficients are positive and highly statistically significant for all types of post-school qualifications. Moreover, the premiums relative to the base group are non-negligible, even in the case of initial vocational education. Unsurprisingly though, the return to education rises remarkably with the level of education. In 2005 the wage increase associated with initial vocational education relative to no post-school qualification was 21.7 per cent (coefficient .196) while the premium to academic education was more than three times higher (71.3 per cent, .538). There are some fluctuations over time. Interestingly, there is a considerable drop in the returns to all qualifications between 1990 and 1995. Presumably, this decrease resulted from the economic downturn which began in 1993. Apparently, all qualification-specific wage premiums move procyclically. After 1995 the returns seem to have recovered, in particular those associated with further vocational education. In 2005 the coefficient of the initial vocational education variable is even slightly above that in 1990. A tendency toward a higher (lower) rewarding of a specific qualification relative to the others cannot be observed though.

\footnotetext{
5 The per cent premiums are calculated by means of the following formula: $\% \Delta$ wage $\approx 100 *\left(\mathrm{e}^{\beta}-1\right)$.
} 


\begin{tabular}{|c|c|c|c|c|c|}
\hline \multicolumn{6}{|c|}{$\begin{array}{l}\text { Model 1a } \\
\text { bighest school qualification combined with highest level of post-school qualification }\end{array}$} \\
\hline \multirow{3}{*}{$\begin{array}{l}\text { lower secondary } \\
\text { schooling }\end{array}$} & \multirow{7}{*}{$\begin{array}{l}\text { initial } \\
\text { vocational } \\
\text { education }\end{array}$} & 1990 & 1995 & 2000 & 2005 \\
\hline & & $.142 * * *$ & $.086 * * *$ & $.107 * * *$ & $.087 * * *$ \\
\hline & & $(.022)$ & $(.021)$ & $(.018)$ & $(.027)$ \\
\hline intermediate & & $.201 * * *$ & $.182^{* * *}$ & $.209^{* * *}$ & $.179 * * *$ \\
\hline secondary & & $(.026)$ & $(.028)$ & $(.020)$ & $(.030)$ \\
\hline \multirow{2}{*}{ Abitur } & & $.349 * * *$ & $.232^{* * *}$ & $.284^{* * *}$ & $.296 * * *$ \\
\hline & & $(.058)$ & $(.033)$ & $(.031)$ & $(.043)$ \\
\hline \multirow{2}{*}{$\begin{array}{l}\text { lower secondary } \\
\text { schooling }\end{array}$} & \multirow{6}{*}{$\begin{array}{c}\text { further } \\
\text { vocational } \\
\text { education }\end{array}$} & $.263^{* * *}$ & $.220 * * *$ & $.269 * * *$ & $.201 * * *$ \\
\hline & & $(.037)$ & $(.036)$ & $(.0269)$ & $(.047)$ \\
\hline intermediate & & $.302^{* * *}$ & $.282 * *$ & $.329 * * *$ & $.242^{* * *}$ \\
\hline secondary & & $(.047)$ & $(.084)$ & $(.031)$ & $(.045)$ \\
\hline \multirow{2}{*}{ Abitur } & & $.454^{* * *}$ & $.267 * *$ & $.404^{* * *}$ & $.335^{* * * *}$ \\
\hline & & $(.045)$ & $(.063)$ & $(.040)$ & $(.032)$ \\
\hline \multirow{2}{*}{\multicolumn{2}{|c|}{ academic education }} & $.589 * * *$ & $.537 * * *$ & $.543 * * *$ & $.496 * * *$ \\
\hline & & $(.038)$ & $(.032)$ & $(.025)$ & $(.035)$ \\
\hline \multicolumn{2}{|l|}{$\mathrm{N}$} & 3,165 & 3,005 & 5,110 & 3,720 \\
\hline \multicolumn{2}{|l|}{$\mathrm{R}^{2}$} & 0.355 & 0.340 & 0.337 & 0.356 \\
\hline
\end{tabular}

dependent variable: natural log of real gross hourly wage.

additional covariates: full-time work experience in years and its square, dummies for gender, nationality, economic sector, firm size.

OLS estimation; standard cross-sectional weights provided in the SOEP were employed; robust standard errors in parantheses; significance levels: * 10\%, ** 5\%,*** $1 \%$.

Source: SOEP (2010), own calculations.

TABLE 5 summarizes the estimation results for Model 1a. This specification conditions the vocationally oriented post-school qualifications on the type of secondary schooling completed. The results presented indicate that the returns to initial and further vocational education are indeed heterogeneous conditional on schooling. The returns to post-school qualifications are particularly high for those who graduated high school (Abitur). Still, further vocational education seems to pay off for lower and intermediate secondary school leavers as well. Over time there is some downward movement in the returns to both initial and further vocational qualifications for all types of schooling. However, this drop is most pronounced for those with lower secondary schooling and initial vocational education. Between 1990 and 2005 the premium declines from 15.3 (.142) to 9.1 per cent (.087). Thus, the strong differences in the returns to initial vocational education conditional on schooling somewhat intensified, while there seems to be some convergence in the returns to further vocational qualifications conditional on secondary school type. Nonetheless, the coefficients of initial vocational education for high school leavers are well above those of further vocational education for lower secondary school leavers at all points in time. ${ }^{6}$ High school leavers may self-select into higher paying occupations, the demand for higher level school leavers may have increased in the area of vocational training or the job assignments have altered more strongly than those for lower level school leavers.

\footnotetext{
${ }^{6}$ Note that initial vocational education and further vocational education usually are sequential, i.e. conditional on the completion if initial training individuals may pursue a further vocational track.
} 
The further differentiation of initial vocational qualifications, i.e. apprenticeships vs. full-time vocational schooling, delivers the following results (TABLE 6). The returns to initial vocational education seem to be in favor of full-time vocational schooling qualifications. However, between 2000 and 2005 the returns to dual apprenticeships and full-time vocational schooling converge somewhat. Overall, the returns to apprenticeships fluctuate more strongly than those to full-time vocational schooling. This may point to a stronger cyclical component of the returns to dual training relative to full-time vocational schooling. Overall, though the returns to full-time vocational schooling are higher than the returns to apprenticeships in all years, this may be less due to their rising absolute importance relative to apprenticeships than to their composition of occupations.

\section{TABLE 6 OLS ESTIMATION RESULTS OF MODEL 2}

\begin{tabular}{|c|c|c|c|c|c|}
\hline \multicolumn{6}{|c|}{$\begin{array}{c}\text { Model } 2 \\
\text { differentiation of initial vocational education qualifications }\end{array}$} \\
\hline \multirow{3}{*}{$\begin{array}{c}\text { initial } \\
\text { vocational } \\
\text { education: }\end{array}$} & & 1990 & 1995 & 2000 & 2005 \\
\hline & $\begin{array}{l}\text { apprenticeship } \\
\text { training }\end{array}$ & $\begin{array}{c}.166^{* * *} \\
(.021)\end{array}$ & $\begin{array}{l}.104^{* * *} \\
(.019)\end{array}$ & $\begin{array}{l}.136^{* * *} \\
(.019)\end{array}$ & $\begin{array}{c}.192^{* * *} \\
(.033)\end{array}$ \\
\hline & $\begin{array}{c}\text { full-time } \\
\text { vocational } \\
\text { schooling }\end{array}$ & $\begin{array}{l}.200 * * * \\
(.029)\end{array}$ & $\begin{array}{l}.227^{* * *} \\
(.041)\end{array}$ & $\begin{array}{l}.181 * * * \\
(.023)\end{array}$ & $\begin{array}{c}.213^{* * *} \\
(.037)\end{array}$ \\
\hline \multicolumn{2}{|c|}{ further vocational education } & $\begin{array}{l}.320^{* * * *} \\
(.029)\end{array}$ & $\begin{array}{l}.251 * * * \\
(.036)\end{array}$ & $\begin{array}{l}.312^{* * *} \\
(.025)\end{array}$ & $\begin{array}{c}.302^{* * *} \\
(.038)\end{array}$ \\
\hline \multicolumn{2}{|c|}{ academic education } & $\begin{array}{l}.587 * * * \\
(.0388) \\
\end{array}$ & $\begin{array}{l}.530^{* * *} \\
(.032)\end{array}$ & $\begin{array}{l}.531 * * * \\
(.026)\end{array}$ & $\begin{array}{c}.538^{* * *} \\
(.039)\end{array}$ \\
\hline & $\mathrm{N}$ & 3,165 & 3,005 & 5,110 & 3,720 \\
\hline & $\mathrm{R}^{2}$ & 0.324 & 0.365 & 0.342 & 0.348 \\
\hline
\end{tabular}

dependent variable: natural log of real gross hourly wage.

additional covariates: full-time work experience in years and its square, dummies for gender, nationality, economic sector, firm size.

OLS estimation; standard cross-sectional weights provided in the SOEP were employed; robust standard errors in parantheses; significance levels: * 10\%, ** 5\%, *** 1\%.

Source: SOEP (2010), own calculations.

Finally, the estimation results for Model 3 are summarized in TABLE 7 . Here dual apprenticeships and further vocational qualifications are differentiated with respect to whether the training was taken in a craft-specific occupation or some other occupation. The identification of the craft population is based on Bizer et al. (2009). Due to data limitations, i.e. training sectors are not reported in the SOEP, the identification of these groups had to be approximated. Accordingly, the craft-specific population refers to those persons who work in an occupation which is specific ${ }^{7}$ to the craft sector and in which they received their training. As a consequence, the population is small and not representative of all individuals who were trained in the craft sector (currently, the sector's share in apprentices is about 30 per cent), but may nonetheless

\footnotetext{
7 This means that persons are sampled only if their current occupation is exclusively trained in the craft sector.
} 
provide an indication of the average return to craft-specific qualifications. Given that the training sector industry \& commerce has a current share in apprentices of about 60 per cent, thus almost making up the rest of the system's total apprentices, we may interpret the returns to 'other' dual apprenticeships as those associated with training in industry \& commerce. Sector-specific interpretations of the returns to further vocational education are not valid, since there is no such separation as in the case of dual apprenticeships. Therefore, the corresponding premiums are rather occupation-specific. Overall, given these restrictions, the results should be interpreted with caution.

TABLE 7 OLS ESTIMATION RESULTS OF MODEL 3

\begin{tabular}{|c|c|c|c|c|c|}
\hline \multicolumn{6}{|c|}{$\begin{array}{c}\text { Model } 3 \\
\text { differentiation of dual apprenticeships according to training sector }\end{array}$} \\
\hline \multirow{3}{*}{$\begin{array}{l}\text { dual } \\
\text { apprenticeships }\end{array}$} & & 1990 & 1995 & 2000 & 2005 \\
\hline & $\begin{array}{c}\text { craft- } \\
\text { specific }\end{array}$ & $\begin{array}{l}.118^{* *} \\
(.046)\end{array}$ & $\begin{array}{c}.074 \\
(.052)\end{array}$ & $\begin{array}{l}.100^{* *} \\
(.044)\end{array}$ & $\begin{array}{l}.123^{*} \\
(.070)\end{array}$ \\
\hline & other & $\begin{array}{l}.168^{* * *} \\
(.021)\end{array}$ & $\begin{array}{l}.105^{* * *} \\
(.020)\end{array}$ & $\begin{array}{l}.138^{* * *} \\
(.019)\end{array}$ & $\begin{array}{c}.195^{* * *} \\
(.033)\end{array}$ \\
\hline \multicolumn{2}{|c|}{$\begin{array}{l}\text { full-time vocational } \\
\text { schooling }\end{array}$} & $\begin{array}{c}.200 * * * \\
(.029) \\
\end{array}$ & $\begin{array}{c}.227 * * * \\
(.041) \\
\end{array}$ & $\begin{array}{c}.182^{* * *} \\
(.023) \\
\end{array}$ & $\begin{array}{c}.213^{* * *} \\
(.038)\end{array}$ \\
\hline \multirow{2}{*}{$\begin{array}{c}\text { further } \\
\text { vocational } \\
\text { education }\end{array}$} & $\begin{array}{c}\text { craft- } \\
\text { specific }\end{array}$ & $\begin{array}{l}.301^{* *} \\
(.119)\end{array}$ & $\begin{array}{l}.231 * * * \\
(.077)\end{array}$ & $\begin{array}{l}.200^{* *} \\
(.094)\end{array}$ & $\begin{array}{l}.342^{* * *} \\
(.065)\end{array}$ \\
\hline & other & $\begin{array}{l}.321 * * * \\
(.030)\end{array}$ & $\begin{array}{c}.231 * * * \\
(.037) \\
\end{array}$ & $\begin{array}{l}.319 * * * \\
(.025)\end{array}$ & $\begin{array}{c}.299 * * * \\
(.038)\end{array}$ \\
\hline \multicolumn{2}{|c|}{ academic education } & $\begin{array}{c}.587 * * * \\
(.038) \\
\end{array}$ & $\begin{array}{c}.531 * * * \\
(.032) \\
\end{array}$ & $\begin{array}{c}.532 * * * \\
(.026) \\
\end{array}$ & $\begin{array}{c}.539 * * * \\
(.039)\end{array}$ \\
\hline \multicolumn{2}{|c|}{$\mathrm{N}$} & 3,165 & 3,005 & 5,110 & 3,720 \\
\hline \multicolumn{2}{|c|}{$\mathrm{R}^{2}$} & 0.325 & 0.365 & 0.363 & 0.348 \\
\hline
\end{tabular}

dependent variable: natural log of real gross hourly wage.

additional covariates: full-time work experience in years and its square, dummies for gender, nationality, economic sector, firm size.

OLS estimation; standard cross-sectional weights provided in the SOEP were employed; robust standard errors in parantheses; significance levels: * $10 \%, * * 5 \%, * * * 1 \%$.

Source: SOEP (2010), own calculations.

In fact, the comparatively low significance levels of the coefficients of craft-specific apprenticeships indicate that these may be less well identified than the others due to their comparatively low number of cases. Alternatively, the returns to craft-specific qualifications which also reflect the returns to craft-specific occupations may be even more prone to cyclical fluctuations than other types of apprenticeships, given their range of products and services. Overall, the returns to craft-specific apprenticeships are below those associated with training in industry \& commerce in all years of observation and the difference is highest in 2005.

As regards the returns to further vocational education, the results are less homogeneous. While in 2000 the return to craft-specific further vocational training is well below the return to other types of further vocational education relative to the reference group of no post-school qualification, the 
ranking is reversed in 2005. Therefore, there is no general penalty to further vocational education in craft-specific occupations as is observable with respect to craft-specific apprenticeships.

\section{CONCLUSION}

At the outset of the paper several research questions were asked relating to recent developments of the dual system of apprenticeship training and other subsystems of the German system of vocational education, and how these may be reflected in the returns to the systems' corresponding qualifications. The following conclusions can be drawn:

Though level differences in the returns to different types of qualifications are important and considerable, there is no clear tendency toward rising or decreasing returns to any specific qualification (Model 1).

The type of secondary school leaving certificate clearly influences the returns to vocational training, i.e. the returns to initial and further vocational education are considerably higher for Abitur holders relative to lower and intermediate secondary school leavers (Model 1a).

The returns to the two types of initial vocational education seem to vary in favor of full-time vocational school qualifications. However, in 2005 the estimated coefficients differ only slightly. Overall, the structural changes within the system of initial vocational education referred to at the beginning are less well reflected in the development of the returns associated with either type of initial training (Model 2).

The returns to crafts-specific dual apprenticeships lose some importance over the period of observation and are below those associated with training in industry \& commerce. This comparatively weak performance cannot be observed for craft-specific further vocational qualifications. The persistent structural weakness of the crafts sector and the drop in the total number of apprentices over the last decades may thus be reflected in the returns to craft-specific apprenticeships, but less so in the returns to craft-specific further vocational education (Model 3). 
Ammermüller, A.; Dohmen, D. (2004), Individuelle und soziale Erträge von Bildungsinvestitionen, Studien zum deutschen Innovationssystem, no. 1-2004, Köln.

Autorengruppe Bildungsberichterstattung (ed.) (2010), Bildung in Deutschland 2010, Bielefeld: W. Bertelsmann Verlag GmbH \& Co. KG.

Baethge, M.; Solga, H.; Wieck, M. (2007), Berufsbildung im Umbruch: Signale eines überfälligen Aufbruchs, Studie: Friedrich-Ebert-Stiftung, Bonn, electronic edition: http://library.fes.de/pdffiles/stabsabteilung/04258/.

Becker, G. S. (1975), Human capital - A theoretical and empirical analysis, with special reference to education, New York: National Bureau of Economic Research, $2^{\text {nd }} \mathrm{ed}$.

Becker, G. S. (1962), Investment in Human Capital: A Theoretical Analysis, The Journal of Political Economy, 70(5. Part 2), pp. 9-49.

Beicht, U.; Walden, G. et al. (2004), Kosten und Nutzen der betrieblichen Berufsausbildung in Deutschland, Bonn: Bundesinstitut für Berufsbildung.

Bizer, K.; Haverkamp, K. et al. (2009), Volkswirtschaftliche Nutzen und Kosten des Handwerkskammersystems, Duncker \& Humblot, Berlin.

Blundell, R.; Dearden, L.; Sianesi, B. (2005), Evaluating the effect of education on earnings: models, methods and results from the National Child Development Survey, Journal of the Royal Statistical Society, 168(3), pp. 473-512.

Card, D. (2001), Estimating the return to schooling: progress on some persistent econometric problems, Econometrica, 69(5), pp. 1127-1160.

Card, D. (1999), The causal effect of education on earnings, in: Ashenfelter, O.; Card, D. (ed.), Handbook of Labor Economics, Volume 3A, Elsevier Science, Amsterdam et al., pp. 1801-1863.

Dearden, L. (1999), Qualifications and earnings in Britain: how reliable are conventional OLS estimates of the returns to education?, Institute for Fiscal Studies, Working Paper Series, No. W99/7.

Dearden, L.; McIntosh, S. et al. (2002), The returns to academic and vocational qualifications in Britain, Bulletin of Economic Research, 54(3), pp. 249-274.

Elliott, R. F. (1997), Labor economics: A comparative text, London: McGraw-Hill. 
Finegold, D.; Wagner, K. (2002), Are apprenticeships still relevant in the $21^{\text {st }}$ century? A case study of changing youth training arrangements in German banks, Industrial and Labor Relations Review, 55(4), pp. 667-685.

Flossmann, A. L.; Pohlmeier, W. (2006), Causal Returns to Education: A Survey on Empirical Evidence for Germany, Jahrbücher für Nationalökonomie und Statistik, 226(1), pp. 6-23.

Franz, W.; Soskice, D. (1995), The German apprenticeship system, in: Buttler, F.; Franz, W. et al. (ed.), Institutional frameworks and labor market performance - Comparative views on the U.S. and German economies, Routledge: London, N.Y., pp. 208-234.

Griliches, Z. (1977), Estimating the Returns to Schooling: Some Econometric Problems, Econometrica, 45(1), pp. 1-22.

Hummelsheim, S.; Timmermann, D. (1999), Finanzierung der Berufsbildung in Deutschland Finanzierungsporträt, Thessaloniki: CEDEFOP.

Jochmann, M.; Pohlmeier, W. (2004), Der Kausaleffekt von Bildungsinvestitionen: Empirische Evidenz für Deutschland, Diskussionspapiere der DFG-Forschergruppe "Heterogene Arbeit", 04/05.

Lauer, C.; Steiner, V. (1999), Returns to human capital in Germany: review of the empirical literature, in: Asplund, R.; Pereira, P.T. (ed.), Returns to human capital in Europe: a literature review, Helsinki: ETLA, The Research Institute of the Finnish Economy, pp. 125-145.

Lindner, A. (1998), Modeling the German system of vocational education, Labour Economics, 5, pp. 411-423.

Mincer, J. (1974), Schooling, experience, and earnings, New York: National Bureau of Economic Research.

Niederalt, M. (2004), Zur ökonomischen Analyse betrieblicher Lebrstellenangebote in der Bundesrepublik Deutschland, Frankfurt am Main [u. a.]: Peter Lang.

Pfeiffer, F. (1997), Die Alterung des Ausbildungswissens nach der Handwerkslehre, in: Seminar für Handwerkswesen (ed.), Der Faktor Humankapital im Handwerk, Kontaktstudium Wirtschaftswissenschaft 1996, Duderstadt: Verlag Mecke Druck, pp. 75-107.

Pfeiffer, F.; Blechinger, D. (1995), Verwertbarkeit der Berufsausbildung im technischen Wandel, in: Franz, W.; Steiner, V. (ed.), Der westdeutsche Arbeitsmarket im strukturellen Anpassungsprozess, ZEWWirtschaftsanalysen, Vol. 39, Baden-Baden, pp. 105-140.

Psacharopoulos, G. (1995), The Profitability of Investment in Education: Concepts and Methods, Human Capital Development and Operations Policy Working Paper, no. 63, World Bank. 
Ruf, M. (2008), Der Übergang von der vollzeitschulischen Berufsausbildung in das Beschäftigungssystem als Herausforderung für die Berufsbildungsforschung: theoretische und empirische Zugänge zum Problem der Akzeptanz vollzeitschulisch erworbener Berufsabschlüsse, Dissertation, Konstanz, electronic resource:

http://www.ub.uni-konstanz.de/kops/volltexte/2008/4854/.

Sachverständigenrat zur Begutachtung der gesamtwirtschaftlichen Entwicklung (2004), Erfolge im Ausland - Herausforderungen im Inland, Wiesbaden: Statistisches Bundesamt.

Schultz, T. W. (1963), The economic value of education, New York: University Press.

Schultz, T. W. (1962), Reflections on investment in man, The Journal of Political Economy, 70(5. Part 2), pp. 1-8.

Soskice, D. (1994), Reconciling markets and institutions: The German apprenticeship system, in: Lynch, L. M. (ed.), Training and the private sector - International comparisons, The University of Chicago Press: Chicago, London, pp. 25-60.

Sölter, A.; Bizer, K. (2010), Renditen konkurrierender Bildungssysteme in Deutschland, WiStWirtschaftswissenschaftliches Studium, 39(2), pp. 76-85.

Timmermann, D. (2005), Bildungsökonomie, in: Tippelt, R. (ed.), Handbuch Bildungsforschung, Wiesbaden: VS Verlag für Sozialwissenschaften/GWV Fachverlage, pp. 81-122.

Willis, R. J. (1986), Wage determinants: a survey and reinterpretation of human capital earnings functions, in: Ashenfelter, O.; Layard, R. (eds.), Handbook of Labor Economics, Volume 1, pp. 524-602.

Wöhe, G. (1996), Einführung in die allgemeine Betriebswirtschaftslehre, 19th ed., München: Vahlen.

Wolter, S. C.; Weber, B. (2005), Bildungsrendite - ein zentraler ökonomischer Indikator des Bildungswesens, Die Volkswirtschaft, 78, pp. 38-42.

Wooldridge, J. M. (2006), Introductory econometrics - A modern approach, Thomson South Western. 


\section{RETURNS TO SCHOOL AND POST-SCHOOL QUALIFICATIONS IN GERMANY - ACCOUNTING FOR FAMILY BACKGROUND AND COGNITIVE ABILITY BIAS}

\section{Abstract}

Using data from the German Socio-economic Panel (SOEP) we depart from the dominant years-of-schooling approach to estimate wage premiums to school and post-school qualifications in Germany. Our contribution to the literature is twofold. First, the separation of school and post-school qualifications and the provision of higher levels of disaggregation of post-school qualifications better reflect the structure of the German educational system and resulting path dependencies than previous studies have. Secondly, account is taken of the endogeneity of educational choice and outcomes by jointly employing comprehensive family background information and different measures of cognitive ability: school grades and results from two ultra-short cognitive ability tests. It can be shown that the endogeneity bias is positive, important in size and increases with the level of post-school qualification. However, if school qualifications are included this bias becomes rather small. 
Differences in individual labor market outcomes and individuals' earnings are driven to a large part by differences in individuals' educational attainment. As a consequence, educational attainment may also be a determinant of intergenerational income as well as social mobility (e.g. Dustmann, 2004). Thus a study of the empirical relationship between education and earnings not only serves as a basis for individual investment decisions, but also provides an important tool for educational, economic or social policy. However, in order to qualify as a meaningful device any analysis of the returns to education should reflect the particularities of a country's educational system and the fact that educational attainment is an endogenous function of both individual and system-based factors. The latter aspect is particularly important if one attempts to recover unbiased estimates of the returns to education. In this paper it is argued that given the specific characteristics of the German system of education it is central not only to account for the heterogeneity in treatments, in particular school and post-school qualifications, but also to consider the joint impact of family background and cognitive ability on educational choice and outcomes. In fact, the aspects of early tracking and the associated dominant role of parental background in determining children's educational attainment as well as the role of individual ability in affecting educational choice and achievement have so far not jointly been discussed in German applications.

More specifically, early tracking refers to the fact that right after primary school (classes one to four) German youth are directed to three different levels of secondary schools. These types of secondary schools differ considerably with respect to study length and curriculum content and provide children with very distinct levels of school qualifications. Individuals' subsequent choice of post-school qualifications is limited by their type of schooling. The tracking nature of the German system of education thus tends to create path dependencies which are generated very early in individuals' educational careers. These path dependencies are somewhat intensified by the existing though somewhat slightly fading dichotomy between vocational and academic tracks, because vocational tracks are usually dominated by lower and intermediate secondary school leavers, whereas academic tracks are more or less restricted to high school graduates.

Furthermore, the relationship between parental background and individuals' educational attainment is particularly pronounced in Germany compared to e.g. Scandinavian countries. Moreover, differences in individual ability will also affect educational choice and outcomes, either directly or indirectly via corresponding family background indicators. More precisely, it is argued that family background and individual ability primarily affect secondary school choice and performance, while post-school educational choice mainly depends upon the level of school 
qualification obtained. Individual ability is then supposed to primarily affect the withindistributions of post-school educational performance.

Overall, while German youth can principally choose from a variety of school and post-school qualifications, these choices are not independent of each other. In addition, the choice of postschool qualification will depend upon the financial return which we expect to differ not only according to level, but also according to type at equivalent levels of education.

These facts and considerations call for both a departure from the years-of-schooling approach and a joint analysis of the determinants of educational choice and the returns to these different choices or qualifications in Germany. Surprisingly, most recent German-based studies maintain the years-of-schooling approach and focus on individual heterogeneity in characteristics and/or returns. In contrast, we stress the importance of treatment heterogeneity, in particular the separation of school and post-school achievement, on the one hand, and the role of (observable) ability and family background on the other hand. Our analysis may thus better reflect the realities of the German educational system.

We estimate wage premiums to school and post-school qualifications in Germany using data from the German Socio-economic Panel (SOEP). Our contribution to the German literature on the returns to education will be twofold. Our analysis will shed more light on the diversity of educational programs individuals can follow and how these are valued by the labor market. More precisely, given the structure of the educational system we separate school from post-school qualifications and estimate premiums to the highest school and post-school qualification an individual has obtained. In addition, we provide separate estimates for two equivalent types of initial vocational education which are usually grouped together.

Also, we will exploit the particular richness of the SOEP in information on respondents' socioeconomic background and individual ability. Not only does the dataset provide comprehensive retrospective information on parents' education and occupation, at the time respondents were 15 years old. The SOEP also contains direct and indirect measures of cognitive ability. Results from two ultra-short IQ-tests represent direct measures of cognitive ability. They have been first introduced to the dataset in 2006 and are available for a subsample of respondents. As an alternative (indirect) measure of cognitive ability, the SOEP additionally comprises information on individuals' grades as obtained in their last school certificate. In following a British strand of the returns to qualifications literature it is argued that both family background indicators and cognitive ability measures are necessary to account for the endogenous selection into school and post-school qualifications. We are the first to analyze the joint impact of cognitive ability and family background on education and wages in a qualification-based approach to the returns to 
education in Germany. Furthermore, the cognitive ability indicators may be used to account for the potential heterogeneity in returns to specific qualifications.

The paper is organized as follows. Section 2 provides a brief description of the German educational system and its particularities. We review the recent literature on the returns to education in section 3, where we focus on German contributions and those which adopt a qualification-based approach. Section 4 presents the dataset and discusses the important variables as well as methodological issues. The estimation results will be provided and discussed in section 5. Section 6 concludes.

\section{INSTITUTIONAL BACKGROUND}

In Germany jurisdiction in all educational matters lies with the federal states (Länder). This adds to the complexity of the German educational system, since many institutions, qualifications etc. are state-specific and very difficult to overlook. Nonetheless, an attempt is made to provide an overview of the most common school and post-school qualifications as well as their underlying institutions. In addition, it is shown that post-school educational choice is mainly determined by the secondary school track followed after primary school.

Primary schooling covers the first four years of school education, after which German youth are directed to either of three basic types of secondary schools: secondary general, intermediate and high schools. Even though there are some mixed forms of schools and specialized high schools, essentially four types of school diplomas can be distinguished (FIGURE 1). They differ with respect to study length and curriculum content. Redirection to either type of secondary school track is conditional on teachers' recommendation which in turn presumably depends upon ability and, predominantly, grades. Interestingly, this teacher recommendation is binding only in six out of 16 states. ${ }^{8}$ Thus, in the majority of states parents ultimately decide about the school (type) their child is going to attend ("Elternwahlrecht"). Hence, parental or family background is the decisive determinant of children's secondary school track choice.

German post-school qualifications are joined in the system of vocational education (FIGURE 1). Within the system of vocational education three subsystems have to be distinguished: the system of initial vocational education, the system of continuing vocational education and the system of higher education.' The former two are sequential, i.e. attendance at a specialized school is conditional on the prior completion of either apprenticeship training or training in the system of vocational schooling. With the exception of the so-called transitory system, all institutions

\footnotetext{
${ }^{8}$ www.vo-saar.de (retrieved 07/29/2010).

${ }^{9}$ A career in the civil service is also possible. There are four different levels of civil service training. Since their discussion does not contribute further to the paper's argument, it will be skipped.
} 
presented in FIGURE 1 are certification-based, i.e. upon successfully completing a program individuals receive a certificate which is generally acknowledged.

\section{FIGURE 1 EDUCATIONAL PATHS IN GERMANY}

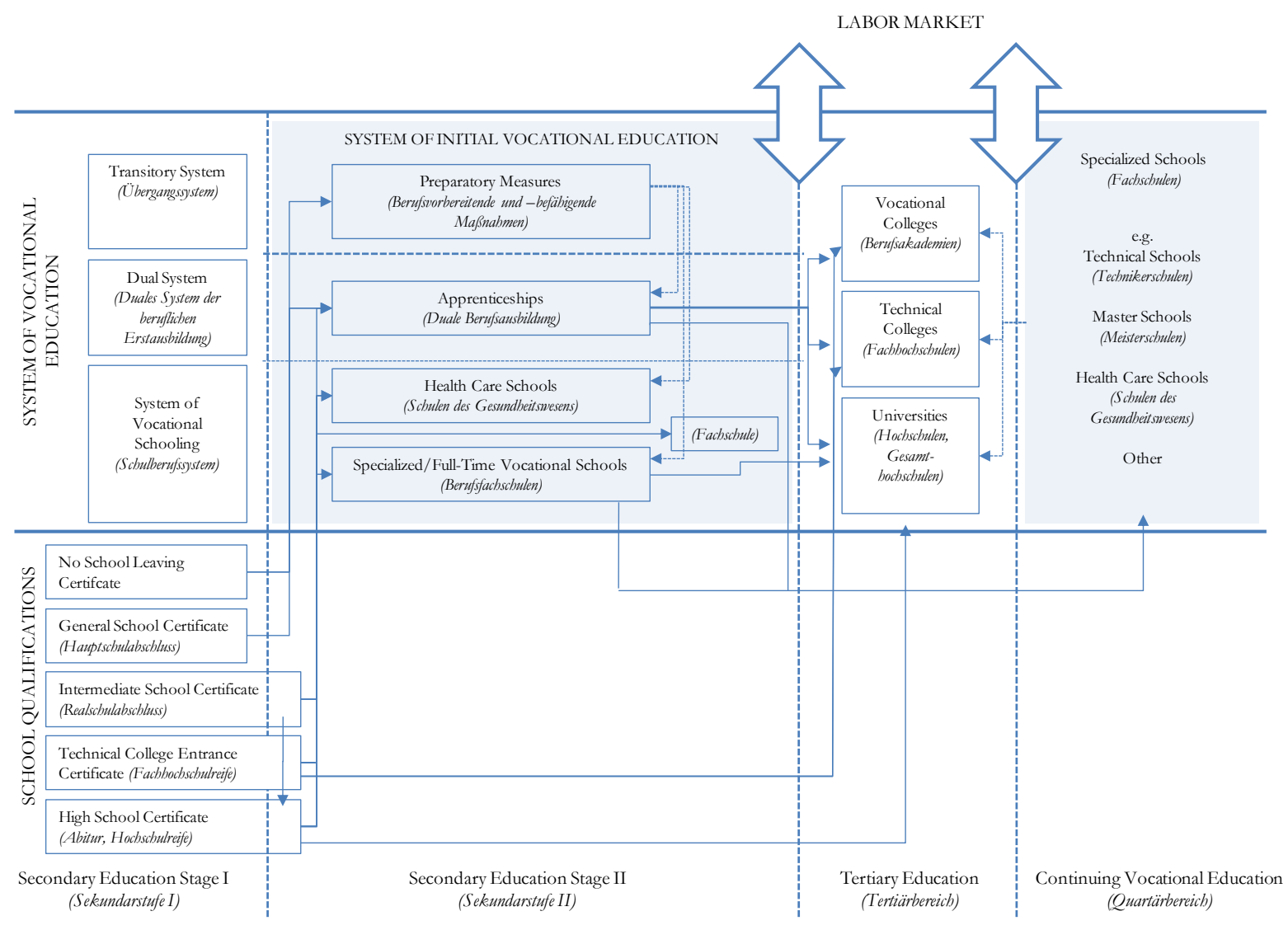

Source: based on Baethge et al. (2007), adapted.

The "choice" of (initial) post-school qualifications is conditioned by the type of school leaving certificate obtained, as indicated by the arrows in FIGURE 1. Grades (observable), individual ability (mostly unobservable) ${ }^{10}$, individual preferences (occupational choice) as well as supply and demand factors constitute additional sorting criteria. Traditionally, individuals who graduated from secondary general and intermediate schools (or left secondary school without a leaving certificate) chose vocational tracks. Most frequently they opted for an apprenticeship place in the dual system. Some of them went on to take courses at a technical or master school to qualify for intermediate management positions or for setting up a business in the crafts sector. In contrast, those with higher schooling levels almost exclusively entered academic education.

This dichotomy is somewhat blurred by the following developments. First, training in the dual system and the system of vocational schooling has become increasingly attractive for higher level

\footnotetext{
${ }^{10}$ Cognitive ability might serve as a determinant if e.g. an acceptance test has to be taken. However, this will only rarely be the case. Job interviews (dual apprenticeships) may rather reveal some non-cognitive skills or personality traits.
} 
school leavers. Reasons are the continuing emergence of new and the upgrading as well as adaptation of existing training occupations. Moreover, holders of high school diplomas (Abitur) might still opt for academic education upon completing initial vocational training. As a result, individuals without a school leaving certificate or a secondary general certificate find it increasingly difficult to enter a full-qualifying program in the system of initial vocation education. Many of them are stuck in the transitory system. Clearly, over time the absorptive capacity of the apprenticeship system for lower skilled school leavers has declined.

Secondly, recent government initiatives support higher levels of achievement for those who initially followed vocational tracks. Access to tertiary education institutions has been facilitated for individuals with intermediate post-school qualifications. Also, school leavers from intermediate schools might still opt for higher level school qualifications in order to pursue academic education afterwards.

Nonetheless, for the majority of school leavers the potential post-school achievement is predetermined by their school qualification. The variety of choices is greatest for Abitur holders, followed by those with a technical college entrance certificate. The lower the school qualification the lower is the choice of post-school qualifications, not only with respect to the type or level of qualification, but also with respect to occupational choice and, consequently, earnings potential. If parents decide about their child's secondary school track, this decision might as well affect their child's future labor market success to some degree. Thus, a separation of school and postschool qualifications in the analysis of the returns to qualifications in Germany seems essential.

\section{REVIEW OF THE LITERATURE}

Given the focus of this paper, the review is mostly restricted to contributions which depart from the years-of-schooling approach. First, problems related to the specification of the education variables are discussed. Secondly, the authors' strategies to account for the endogenous selection into qualifications and related estimation issues are reviewed.

\section{Specification issues}

Over the last 40 to 50 years a large amount of literature on the returns to education has piled up. Theoretically, this literature builds on Becker's human capital theory (1975) and the idea that human capital can be accumulated by devoting time and other resources to education, thereby raising productivity and, consequently, translating into higher wages. Empirically, Mincer's (1974) wage equation framework is the basic analytical tool. The bulk of the studies, among them the most influential, are from the United States. Card (2001, 1999) and Griliches (1977) provide comprehensive reviews for this strand of literature. US-based publications for the most part treat 
schooling or education as a continuous variable. In contrast, the UK-based literature has some tradition in accounting for the heterogeneity in treatments based on different levels or types of educational attainment; see e.g. Blundell et al. (2005) for a recent review. Dearden (1999) distinguishes five school and five post-school qualifications and estimates the returns to both the highest level of schooling and post-school education individuals have attained. Similarly, Blundell et al. (2005) estimate the returns to the highest level of qualification. However, they do not separate school from post-school qualifications and distinguish only four treatments. In contrast, Dearden et al. (2002) include all the qualifications individuals have obtained in order to better account for the sequential nature of educational attainment and the possible variation in routes individuals may or may not take during their acquisition of formal qualifications. In particular, they focus on the distinction between vocational and academic qualifications and the potential heterogeneity in the returns to equivalent levels of qualification.

Reviews of the German return literature illustrate that German studies mostly follow the US tradition (Flossman \& Pohlmeier, 2006; Lauer \& Steiner, 1999). This is somewhat puzzling since the estimation of program returns has often been deemed important for educational track systems like the German (e.g. Flossmann \& Pohlmeier, 2006). There are a few studies which estimate qualification-specific wage premiums in Germany. Recent contributions are Anger \& Lupo (2007), Ammermüller \& Weber (2005), Dustmann (2004) and Lauer \& Steiner (2000). Their analyses are all based on data from the SOEP. However, with the exception of Dustmann (2004), the studies do not separate school from post-school qualifications. Moreover, the types of post-school qualifications distinguished display relatively high levels of aggregation and are varying across studies. Sometimes their composition seems somewhat arbitrary. In part this is due to data limitations. Yet, some categories are simply not compatible with the existing educational structure. $^{11}$

More specifically, Dustmann (2004) distinguishes three school qualifications and five types of post-school qualifications. In contrast, Anger \& Lupo (2007) and Ammermüller \& Weber (2005) distinguish four different levels of post-school qualification, while Lauer \& Steiner (2000) distinguish six education categories with some mix of school and post-school qualifications. Overall, the categories and the corresponding types of qualification are somewhat difficult to compare across contributions since mostly they are not well or not at all explained. This is particularly true for the classes of basic and further vocational qualifications. As far as basic vocational education is concerned, the two basic types to be distinguished are apprenticeships

\footnotetext{
${ }^{11}$ A more comprehensive account of the exact composition of the qualification categories is given in TABLE A1 in the appendix.
} 
and training at full-time vocational schools. ${ }^{12}$ Though Dustmann (2004) separates blue collar and white collar apprenticeships it is not clear whether his definition corresponds to a distinction of the two institutions providing initial vocational education. In contrast, Ammermüller \& Weber (2005) make no such distinction, while Anger \& Lupo (2007) seem to "upgrade" full-time vocational schools and health care schools. Furthermore, it is not clear whether the category “apprenticeship" used by Lauer \& Steiner (2000) indicates integration of all three types of initial vocational training or simply dual apprenticeships.

The placement of persons with a high school diploma causes additional irritation, again with the exception of Dustmann (2004). Ammermüller \& Weber (2005) assign them to their "intermediate" category. On the contrary, Lauer \& Steiner (2000) create an additional category including all persons with a high school diploma, however irrespective of their post-school qualification (initial or advanced).

In conclusion, the specification of the education categories in the reviewed papers is far from homogeneous and only partly reflects the formal structure of the German educational system. Unfortunately, the exact composition of the categories is frequently not made explicit. Where defined, criteria such as the distinction of school and post-school qualifications as well as the formal equivalence of qualifications grouped together have not been sufficiently met. In addition, a further (complete) disaggregation of post-school qualifications is desirable, but seems difficult due to data limitations. Nonetheless, this paper provides some improvement in this respect.

\section{Estimation issues}

The returns-to-qualifications analyses in Blundell et al. (2005), Dearden et al. (2002) and Dearden (1999) are based on the so-called selection-on-observables assumption, i.e. factors that affect both education decisions and wage outcomes are observable or well proxied by the variables available. Accordingly, conditional on some set of covariates qualifications can be treated as exogenous and ordinary least squares (OLS) estimation yields unbiased estimates of the returns to qualifications. While Dearden et al. (2002) and Dearden (1999) exclusively rely on OLS, Blundell et al. (2005) also provide matching estimators. All three contributions exploit the particular richness of the National Child Development Survey (NCDS), a longitudinal study of a British cohort born at the beginning of March in 1958. More specifically, the NCDS includes direct ability measures, i.e. test scores in reading and mathematics at ages 7 and 11 , extensive family

\footnotetext{
12 As indicated in FIGURE 1 health care and nursery schools form an independent pillar of the system of vocational schooling (Ruf, 2008, p. 82). Accordingly, health care schools provide basic vocational education (Baethge et al., 2007, p. 15). However, since 2001 the SOEP assigns health care schools to the category "technical schools" which provide further vocational education and require either completed basic vocational training or sufficient work experience in the respective area of training. Therefore, assignment to either category probably is conditional on individuals' previous education.
} 
background information such as parents' interest in child's education, parents' education, father's social class and indicators of financial difficulties (at ages 11 and 16) as well as a variable indicating school type.

The importance of including (early) ability and family background information into the wage equations is confirmed by the results in all three analyses. Not only do ability and some family background variables significantly affect wages (Dearden, 1999), their inclusion also lowers the OLS estimates of the returns to qualifications non-negligibly compared to those obtained from a “conventional specification"13 (Blundell et al., 2005; Dearden et al., 2002; Dearden, 1999). According to Dearden et al. (2002) and Dearden (1999) this points to some correction of the potential positive bias arising from missing ability and family background information.

OLS produces homogeneous return estimates, i.e. the return to a specific level of education does not differ across individuals. However, it is reasonable to assume that the return estimates differ by ability or by family background. Dearden et al. (2002) and Dearden (1999) allow for such observable heterogeneity. With respect to ability-related heterogeneity, they split their sample into two ability groups (low and high ability) and interact these with the education variables. Dearden (1999) finds no evidence for the heterogeneity in the returns to the highest school and postschool qualifications between the two groups. Similarly, Dearden et al. (2002) finds that the premiums to academic qualifications do not differ considerably between low and high ability individuals. However, the premiums to vocational qualifications are more favorable for the lowability group. Dearden (1999) additionally employs interactions including family background information. Family financial circumstances seem not to affect the returns. However, there seems to be some negative link between the return to qualifications and father's education, whereas mother's interest in child's education has a mixed impact.

The German studies which provide estimates of the returns to different levels of qualification also mostly rely on simple OLS. However, they do not control for ability or family background bias. Also, they do not account for potential observable heterogeneity in the return estimates as considered in the UK-based studies discussed above. More specifically, Ammermüller \& Weber (2005) implement the standard Mincer-wage-equation framework to estimate the returns to qualification levels using a cross-section from the SOEP 2002, i.e. education, work experience and work experience squared are the only variables included in the regression. The wage premiums are adjusted for the average additional years spent to complete the level of qualification (as compared to the reference category). However, since the composition of the intermediate

\footnotetext{
${ }^{13}$ The conventional specifications differ in some respects in the three contributions. Region of residence at age 16 is the only covariate in Dearden (1999), while Blundell et al. (2005) additionally include ethnicity. In contrast, Dearden et al (2002) use the UK Labour Force Survey to estimate their conventional model including age, ethnicity, region, firm size and public sector.
} 
category is such that the study time variance will be considerable, the resulting estimates may be less accurate.

Similarly, Lauer \& Steiner (2000) adopt the standard Mincer framework. However, for a West German sample they provide qualification-specific wage premiums and yearly returns over time (1984 to 1997). They show that study duration adjustment can be important since it may change the ranking between levels of qualification with respect to their corresponding return. More specifically, the wage premiums deliver the usual picture, i.e. the higher the level of education the higher the premium. Yet, the "Master" category jumps from second last to first as soon as yearly returns are considered. According to the authors this can be attributed to the comparatively short period of study. Over time the return to "high school" decreases considerably, becoming the least favorable in the last year of observation. Recall that the composition of this category is inadequate in terms of the equivalence of the qualifications included. In addition, the caution expressed with respect to the study duration adjustment in Ammermüller \& Weber (2005) applies accordingly.

Anger \& Lupo (2007) augment the standard wage equation and account for firm size, economic sector and year effects. They also include socio-demographic variables such as age, marital status and children in the household. ${ }^{14}$ The wage premiums which are estimated for a sample of fulltime employed persons using the 1991 to 2005 waves from the SOEP by region (East, West) are on average lower than those in Lauer \& Steiner (2000).

An important extension to the above studies is provided by Dustmann (2004) who studies the association between family background, education and earnings in Germany. He presents descriptive evidence for the association between parental background (education, occupational position) and secondary school track and also shows how school track and post-school achievement are related. ${ }^{15}$ Dustman (2004) argues that individuals' wage is affected by family background only via its impact on educational attainment. Therefore, the family background variables do not enter the multivariate analysis of a seven-year panel of SOEP data (1984-1990). Overall, he concludes that the inter-generational mobility with respect to educational attainment and thus income is negligible.

Finally, Anger \& Heineck (2010) and Heineck \& Anger (2010) are worth consideration. They were the first to use the SOEP's recently introduced two ultra-short ability tests in a wageequation framework. Anger \& Heineck (2010) study the separate impact of both test scores on wages and how their inclusion affects the return to an additional year of schooling for a crosssection of West-German, full-time working individuals. Also, interactions between the test scores

\footnotetext{
${ }^{14}$ The variables were not explicitly described in the paper, but were made available upon request.

15 See also Lauer (2003) for an empirical analysis of the determinants of educational attainment in Germany and the important role of parental background.
} 
and the schooling variable are analyzed. Both OLS and two-stage least squares (2SLS) estimates are provided, the latter correcting for the potential bias arising from the selection into full-time employment. Overall, the impact of the two scores on both the return estimates and wages is mixed. The authors conclude that education and (cognitive) ability are inseparable determinants of earnings and therefore, interaction effects are more important than main effects.

Heineck \& Anger (2010) focus on the direct impact of cognitive ability and personality traits (non-cognitive skills) ${ }^{16}$ on wages and disregard how their inclusion affects the return to education. They construct a longitudinal sample with observations ranging from 1991 to 2006 and provide pooled OLS, random effects and Hausman-Taylor instrumental variables estimates. All three variants produce a positive and significant impact of cognitive ability on male wages only, however with the coefficients being slightly larger in the panel estimations than in the pooled OLS specification.

Overall, the UK studies show that a years-of-schooling approach is not suitable for a system characterized by treatment heterogeneity, since the return to an additional year of schooling is not constant across qualifications. However, they also stress the importance of directly controlling for differences in ability and family background. While some German studies (insufficiently) account for the former, very few others partly account for the latter. This paper's empirical contribution is a combination of both.

\section{METHODOLOGY}

\section{Data set and sampling issues}

We use data from the most recent version of the German Socio-economic Panel (SOEP v26). The SOEP is a longitudinal survey of households and persons living in Germany. ${ }^{17}$ The data are provided by the German Institute for Economic Research (DIW) and are available since 1984 (New Länder since 1990). The SOEP questionnaires cover a very wide range of topics including current life and job, current and retrospective information on education, childhood and family, to name just a few.

Comprehensive family background information and three indicators of individual ability are used as direct controls for the endogeneity of school and post-school qualifications. Joint availability and completeness of all sets of information would be most favorable, but is seldom possible in

\footnotetext{
16 The items used to identify an individual's personality are based on the so-called Five-Factor-Model and additionally include measures of locus of control and reciprocity. Since this paper focuses on cognitive ability, noncognitive skills will not be considered further. It has to be noted though that some of the personality traits seem to have a stronger impact on wages than the cognitive ability measure. In particular, the association between parental background and the development of non-cognitive skills provide interesting research opportunities.

17 The Desktop Companion to the German Socio-Economic Panel (2005) is a comprehensive and helpful introduction to the dataset. For item correspondence lists, word and variable search check the online tool soepinfo.
} 
comprehensive data sets such as the SOEP. ${ }^{18}$ Our way of ensuring sufficient sample size and dealing with potentially non-random item non-response is to explicitly control for missing information on either family background, the cognitive ability tests or grades and to pool ${ }^{19}$ ten cross-sections (2000 to 2009). In this way, a sample with a total of 6,994 person-year observations (from 1,505 individuals) could be generated which includes all employed individuals aged 18 to 65 who obtained their school and post-school qualifications in Germany and who work in a fulltime or part-time job.

Note that the analysis is not restricted to any specific subsample. Unsurprisingly, given the period of observation most of the observations are from samples F (Innovation, 2000: 62.3 per cent), G (High Income, 2002: 15.3 per cent) and H (Refreshment, 2006: 18.8 per cent). ${ }^{20}$ To correct for oversampling we weight our data with the cross-sectional weights as provided in the standard data distribution. ${ }^{21}$

\section{The basic empirical model, descriptive statistics and variable construction}

The brief description of the German system of education and the literature review clearly indicated that in order to adequately study the returns to qualifications in Germany both a departure from the years-of-schooling approach and a separation of school and post-school educational attainment are essential. In addition, given the institutional structure of the system, we expect school and post-school qualifications to be interdependent. Moreover, parental background and cognitive ability seem to drive both education and wages. Our model of the determinants of education and wages can be estimated using an augmented Mincer-type wage equation of the following type:

$\ln w_{i t}=\beta_{1}^{\prime} S Q_{i t}+\beta_{2}^{\prime} P S Q_{i t}+\theta^{\prime} X_{i t}+\delta^{\prime} X_{i}+\varepsilon_{i t}$

The time subscripts indicate that we pooled our ten cross-sections over time and that some of our variables are time-variant. More precisely, the dependent variable is the natural logarithm of individuals' real gross hourly wage rate. ${ }^{22} S Q_{i t}$ and $P S Q_{i t}$ are vectors of individuals' highest

\footnotetext{
18 Most importantly, the ability test scores were introduced in 2006 and are restricted to a subsample of the total sample in that wave.

${ }^{19}$ The idea to pool cross-sections to increase the sample size is based on Heineck \& Anger (2010).

${ }^{20}$ Our samples contain the SOEP subsamples A to H. Observations from the Incentivation Sample (2009) were not selected, since these persons did just enter the SOEP and thus did not participate in the 2006 cognitive ability tests.

${ }^{21}$ Analytic weights (aweight command in Stata) were used for the descriptive statistics, while in the regressions the pweight option (probability weights) was used. Probability weights account for differences in sampling probability. The pweight option was however not allowed to be used with the summarize command (descriptive statistics). Therefore the aweight option had to be employed.

22 The variable is constructed by means of the generated variables for the current monthly gross labor income, deflated, and the actual hours worked per week. To calculate the hourly wage, measures of 4.348 weeks per month and 365.25 days per year are assumed (leap years considered) (Skarupke, 2005, p. 54). The annual information on work hours and labor earnings from the Cross-National-Equivalent-File was considered as well. However, the annual work hours refer to the previous year. Moreover, the annual labor earnings variable is said to be a very crude
} 
school and post-school qualifications. $\beta^{\prime}{ }_{1}$ and $\beta^{\prime}{ }_{2}$ are vectors of coefficients measuring the wage premiums to the different school and post-school qualifications, respectively. $X_{i t}$ is a vector of time-variant covariates, while the vector of time-constant regressors is $X_{i} . \varepsilon_{i t}$ is the idiosyncratic error term which is assumed to be uncorrelated with the regressors.

The following discussion concentrates on the construction of the education variables and the sets of time-constant variables which control for the endogeneity of school and post-school qualifications, i.e. family background, the cognitive ability tests and school grades. Also, the way in which missing data are dealt with is described. Descriptive statistics for these variables are reported in TABLE $1 .{ }^{23}$

The SOEP provides generated variables on individuals' highest school and post-school qualifications and dummy sets were defined accordingly. The data allow a distinction of five levels/types of school qualifications which fully reflect the structure of the basic available school qualifications as presented in section 2: no school leaving certificate, secondary general school, intermediate secondary school, technical college entrance certificate and high school.

In contrast, a full account of the basic types of post-school qualifications cannot be given. ${ }^{24}$ Recall that the SOEP's generated variables do not distinguish the different levels of civil servant training. Corresponding observations are thus dropped from the analysis. Furthermore, no separate information is provided about whether an individual graduated from a vocational college (Berufsakademie). Nonetheless, five types of post-school qualifications could be generated with the reference category being no post-school qualification: apprenticeship training and full-time vocational schooling as the two types of initial vocational education, further vocational education, and technical college as well as university education, the latter two representing qualifications at the academic level.

As regards family background, the SOEP contains information referring to the time when respondents were 15 years old. More specifically, we employ five sets of dummy variables reporting parents' highest post-school qualification as well as their then occupational position and whether parents showed interest in their child's school performance (see TABLE 1). Parents' education and occupation are defined similar to those in Lauer (2003). For each of the five sets of dummy variables one additional dummy was generated to account for item non-response and non-applicable information.

measure and less consistent in terms of individual's current employment status, occupational position and working time.

${ }^{23}$ The additional covariates used in the estimations are summarized in TABLE A2 in the appendix.

${ }^{24}$ Potentially, a further disaggregation might be possible as the structure of the questionnaires indicate. However, this information is not (to our knowledge) part of the standard data distribution and possibly involves considerable time and computational effort. 


\begin{tabular}{|c|c|c|c|c|}
\hline \multirow[b]{2}{*}{ Variables } & \multicolumn{4}{|c|}{$\begin{array}{c}\text { Pooled Sample } \\
(\mathrm{N}=6,994)\end{array}$} \\
\hline & Mean & S.D. & Min & Max \\
\hline \multicolumn{5}{|l|}{ School qualification } \\
\hline no school leaving certificate (obne Schulabschluss) & 0.02 & 0.12 & 0 & 1 \\
\hline secondary general (Haupscbule) & 0.39 & 0.49 & 0 & 1 \\
\hline intermediate (Realschule) & 0.33 & 0.47 & 0 & 1 \\
\hline technical college entrance certificate (Fachbocbschulreife) & 0.06 & 0.25 & 0 & 1 \\
\hline high school (Abitur/Hocbscbulreife) & 0.21 & 0.40 & 0 & 1 \\
\hline \multicolumn{5}{|l|}{ Post-school qualification } \\
\hline none (kein Berufsabscbluss) & 0.07 & 0.26 & 0 & 1 \\
\hline apprenticeship (duale Ausbildung) & 0.58 & 0.49 & 0 & 1 \\
\hline full-time vocational school (Berufsfachscbule) & 0.09 & 0.28 & 0 & 1 \\
\hline specialized school (Fachschule) & 0.07 & 0.25 & 0 & 1 \\
\hline technical college (Facbhochschule) & 0.07 & 0.26 & 0 & 1 \\
\hline university (Universität, Hochscbule) & 0.12 & 0.33 & 0 & 1 \\
\hline \multicolumn{5}{|l|}{$\overline{C o g n i t i v e ~ a b i l i t y ~}$} \\
\hline word fluency test (WFT) & 20.75 & 14.35 & 0 & 82 \\
\hline WFT miss & 0.20 & 0.40 & 0 & 1 \\
\hline symbol correspondence test $(\mathrm{SCT})$ & 22.75 & 14.66 & 0 & 56 \\
\hline SCT miss & 0.22 & 0.41 & 0 & 1 \\
\hline average grade last school certificate & 2.73 & 0.67 & 1 & 5 \\
\hline grade miss & 0.14 & 0.35 & 0 & 1 \\
\hline \multicolumn{5}{|l|}{ Father's education } \\
\hline no vocational qualification & 0.09 & 0.29 & 0 & 1 \\
\hline basic vocational education & 0.73 & 0.45 & 0 & 1 \\
\hline intermediate vocational education & 0.001 & 0.02 & 0 & 1 \\
\hline civil servant training & 0.003 & 0.06 & 0 & 1 \\
\hline higher education & 0.09 & 0.28 & 0 & 1 \\
\hline missing & 0.09 & 0.28 & 0 & 1 \\
\hline \multicolumn{5}{|l|}{ Mother's education } \\
\hline no vocational qualification & 0.34 & 0.48 & 0 & 1 \\
\hline basic vocational education & 0.48 & 0.50 & 0 & 1 \\
\hline intermediate vocational education & 0.001 & 0.03 & 0 & 1 \\
\hline higher education & 0.04 & 0.19 & 0 & 1 \\
\hline missing & 0.14 & 0.34 & 0 & 1 \\
\hline \multicolumn{5}{|l|}{ Father's occupational position } \\
\hline farmer & 0.04 & 0.20 & 0 & 1 \\
\hline worker & 0.43 & 0.49 & 0 & 1 \\
\hline employee & 0.04 & 0.20 & 0 & 1 \\
\hline middle manager & 0.19 & 0.39 & 0 & 1 \\
\hline senior manager & 0.12 & 0.32 & 0 & 1 \\
\hline self-employed & 0.07 & 0.25 & 0 & 1 \\
\hline not employed, other (missing) & 0.11 & 0.31 & 0 & 1 \\
\hline \multicolumn{5}{|l|}{ Mother's occupational position } \\
\hline farmer & 0.01 & 0.10 & 0 & 1 \\
\hline worker & 0.20 & 0.40 & 0 & 1 \\
\hline employee & 0.02 & 0.14 & 0 & 1 \\
\hline middle manager & 0.18 & 0.39 & 0 & 1 \\
\hline senior manager & 0.03 & 0.17 & 0 & 1 \\
\hline self-employed & 0.06 & 0.23 & 0 & 1 \\
\hline not employed, other (missing) & 0.51 & 0.50 & 0 & 1 \\
\hline \multicolumn{5}{|l|}{ Parents showed interest in child's school performance } \\
\hline very much & 0.16 & 0.36 & 0 & 1 \\
\hline quite a lot & 0.44 & 0.50 & 0 & 1 \\
\hline not a lot & 0.34 & 0.47 & 0 & 1 \\
\hline not at all & 0.06 & 0.23 & 0 & 1 \\
\hline missing & 0.003 & 0.05 & 0 & 1 \\
\hline
\end{tabular}

Source: Socio-economic Panel (SOEP) (2010), own calculations. 
Furthermore, three measures of cognitive ability are used. The results from two ultra-short cognitive ability tests ${ }^{25}$ are assumed to be rather explicit measures of cognitive ability. These test scores are very innovative and have been first introduced to the SOEP in 2006. More specifically, the symbol correspondence test (SCT) and the word fluency test (WFT) are indicators of individuals' innate abilities and their experience-related (educational) competencies, respectively (Heineck \& Anger, 2010; Lang et al., 2007). ${ }^{26}$

Raw measures of both test results were employed. The considerable number of "zero-scores" in the test sample to a large part reflects item non-response (refusal to participate). These were summarized in two additional dummies referring to missing information in the two tests. The small number of apparently actual scores of zero ${ }^{27}$, which technically do not represent missing information, entered the test variables.

The third measure is an average grade calculated from three different subjects as obtained in the last school certificate: German literature, mathematics and the first foreign language. Frequently, one or more grades were not reported. In order to keep as many observations as possible, the average was computed using those grades (the grade) available for each individual. However, to control for potential non-random missing grade information, an additional dummy was created indicating whether one or two grades were missing. ${ }^{28}$

\section{Specification issues and the expected impact of education, family background and ability}

For the estimations the five school qualifications had to be reduced to four, because of collinearity issues. ${ }^{29}$ Thus, the default category with respect to school qualifications is "no schooling certificate" or "secondary general schooling". 30

\footnotetext{
25 See Schupp et al. (2008) for a documentation of test methodology, participation and results as well as a variable description and Lang et al. (2007) for issues relating to conception, reliability and validity in the pre-test period.

${ }^{26}$ In the SCT as many digits as possible have to be assigned to symbols in 90 seconds, while in WFT respondents have to name as many animals as come to their mind within 90 seconds.

${ }^{27}$ It is not clear whether these persons either refused to continue after they had started the test or had not produced a score after the time had elapsed.

${ }^{28}$ The item 'does not apply' was introduced only in 2002. Before, the 'no answer' category must have been a mix of both 'no answer' and 'does not apply'. Interestingly, foreign language grades were much more often given a 'no answer' if inquired before 2002 and a 'does not apply' since 2002 as compared to the German and math grades. In fact, foreign language courses may not have been compulsory or not have been taught at all at lower level secondary schools. However, this will apply mainly to older persons in the sample. However, since any subsequent redirection would have been arbitrary in some way and could thus have worsened any potential bias, we left the available information unchanged.

${ }^{29}$ The variance inflation factor (vif), $\left(1-R_{k}^{2}\right)^{-1}$, where $R_{k}^{2}$ is the partial $R^{2}$ from a regression of the $k^{\text {th }}$ regressor on all other regressors, can be used to detect near-collinearity. The vif command is a post-estimation command (Baum, 2006, pp. 84). Estimation of Models 2 (baseline) and 2a (full) (see TABLE 3) produced the following vifvalues: 17.30/20.35 (secondary general), 16.29/19.32 (intermediate) and 13.62/16.07 (high school). Baum (2006, p. 85) states that vif values larger than 10 are usually worrisome.

${ }^{30}$ Omission of the secondary general category let the vif-values of the intermediate and high school categories drop to below four in both specifications.
} 


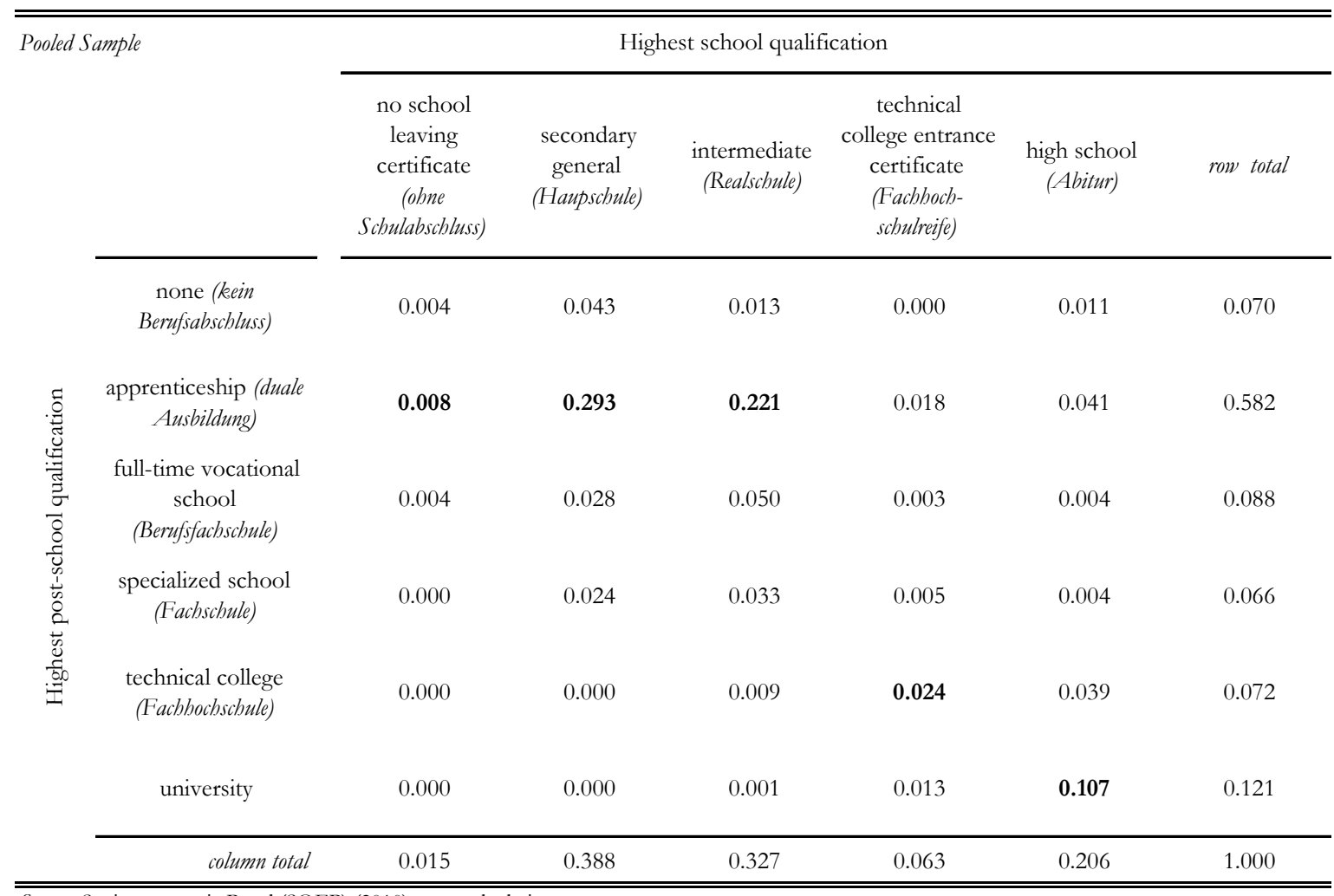

Source: Socio-economic Panel (SOEP) (2010), own calculations.

TABLE 2 shows that there is strong correlation between the type of schooling and the "choice" of post-school qualification. The figures in bold refer to the type of post-school qualification obtained by the majority of individuals conditional on the type of schooling. The aforementioned path dependencies, in particular the dichotomy between lower/intermediate level school leavers and vocational paths as well as higher level school leavers and academic paths, are apparent. However, in the regressions there was no sign of collinearity between school and post-school qualifications and thus no further investigation required.

Since post-school qualifications and future labor market opportunities are not independent of schooling, it is insightful to analyze their wage effects separately. It is particularly interesting to look at how the returns to post-school qualifications are affected by the inclusion of the schooling variables. In fact, the returns to school qualifications may be even more important in size than the returns to post-school qualifications since school education lays the crucial groundwork for subsequent investments in human capital. Furthermore, since school and postschool qualifications are interdependent, their separation may account for part of the nonrandom selection into post-school qualifications.

Now consider the impact of parental background. It is assumed that family background affects individuals' future wages in two ways. First, parents' right to determine their child's secondary 
school track ${ }^{31}$ affects both post-school educational opportunities and, ultimately, labor income prospects. Moreover, parents' occupation and education reflects household financial and other resources. In addition, parents' education and occupation may directly affect their offspring's own ambitions, career or occupational aspirations and, eventually, wage outcomes. Overall, parental background will influence the cost-to-return ratios associated with different levels of education or, at least, the perception of them.

Finally, let's turn to the measures of cognitive ability. The test scores are jointly employed in the estimations. Heineck \& Anger (2010) dropped the WFT from their analysis because of potential measurement error and the argument that it may not be a pure measure of crystallized intelligence. However, the SCT is probably not completely free of measurement error either, since some of the participants performed the test directly at the computer, while others let the interviewer type in their answers. Furthermore, some respondents will be more proficient computer users than others and this might to some degree affect the SCT test results. In fact, in the pre-tests the SCT scores were significantly correlated with computer expertise in the first occasion (0.34), but less so in the re-test (0.12) (Lang et al., 2007, p. 188). Secondly, the two tests were specifically designed to account for two different concepts of intelligence or cognitive ability which complement each other.

A more severe problem could be that the two cognitive ability measures are not pre-school measures of individuals' cognitive abilities. After all, Blundell et al. (2005) explicitly stress the importance of so-called "pre-treatment" ${ }^{32}$ indicators. Possibly, individuals would have performed differently in the tests if they had taken them at the beginning of or before primary school. Validation tests of the test scores showed that the WFT is significantly correlated with individuals' education (measured in years), while the SCT is significantly correlated with individuals' age (Lang et al., 2007). In our sample no such dependency could be detected. Therefore, it seems reasonable to interpret the two measures as "pre-treatment" indicators and employ them unadjusted.

However, the two tests are highly correlated themselves (0.73). Part of this correlation might reflect participation behavior rather than the association between test results. Collinearity on the other hand was not an issue in the estimations. Hence, the impact of the WFT and SCT is sufficiently separable and their joint inclusion is in order.

\footnotetext{
31 Note that children are streamed into secondary school tracks when they are about 10 years old, while the information available is related to the time when respondents were 15 years old. We just assume that parents' situation then is not considerably different from that five years before. This assumption is not implausible, in particular regarding parents' interest in their child's school performance or parents' education.

32 The persons in our sample(s) are all working and the ability tests were taken when they had already completed their formal education.
} 
How do the cognitive ability tests account for endogenous schooling? It was suggested earlier that parental background affects children's secondary school track choice. Still, we do not expect parents' choice to be completely independent of teachers' recommendations. The latter should represent an objective evaluation of children's primary school performance. If children are subject to grading, differences in final grades will reflect differences in performance. If there is no grading, children will nonetheless be evaluated in terms of their overall performance. Intuitively, we expect differential performance to be affected by differences in cognitive ability. ${ }^{33}$ In contrast, the choice of post-school qualifications will be largely determined by the level of secondary school. Given a specific level of secondary school, we expect differences in cognitive ability to affect students' performance distribution and, consequently, their final grades. The latter will additionally affect students' range of choice of post-school qualifications.

The above discussion suggests a further analysis of the relation between the tests and education. Is there a combined effect which is linear across the test score distribution or are there nonlinearities? These aspects of heterogeneity in the returns to education will also be analyzed in the empirical analysis.

Presumably, cognitive ability also affects the wage distribution directly. And even though this association is not the prior focus in this paper, some related thoughts are worth consideration. ${ }^{34}$ Overall, we expect individuals with higher cognitive ability to yield higher wage premiums. However, the effects of the WFT and SCT may differ. If the WFT reflects learning capacity or the stock of knowledge and the SCT covers learning or performance efficiency as well as the ability to process (new) information, the latter may be valued more strongly by employers. In fact, workplace computerization and the upgrading of the skill-content of occupations also known as skill-biased technological change have considerably changed employers' skill requirements. SpitzOener (2006) finds that occupations have indeed become considerably more complex during the last three decades and that most of this structural change has occurred within rather than across occupations. More specifically, there has been a shift away from routine cognitive and manual activities towards non-routine analytic and interactive tasks. ${ }^{35}$ We suggest that the latter are much more reflected by the SCT than the WFT and thus we expect the SCT test scores to have a stronger impact on wages than the WFT scores. On the other hand, cognitive ability, in particular as measured by the SCT, may be unobservable to employers and thus difficult to be rewarded directly.

\footnotetext{
${ }^{33}$ Non-cognitive traits may also play a role, but will not be discussed further in this paper (see Heineck \& Anger, 2010).

34 See Heineck \& Anger (2010) for a more detailed analysis for the impact of the SCT on wages in Germany.

${ }^{35}$ Non-routine analytic tasks are defined as e.g. researching, analyzing, evaluating and planning, designing, using and interpreting rules, while non-routine interactive tasks refer to e.g. negotiating, organizing, lobbying, teaching and service-related activities like selling or advising customers (Spitz-Oener, 2006, p. 243).
} 
Finally, the computed average school grade as an alternative or supplementary measure of cognitive ability requires some discussion. It was already suggested that cognitive ability and school grades may be related. It is not clear however whether the concepts of cognitive ability as measured by the WFT and SCT also reflect what is measured by such an average school grade. In fact, Lang et al. (2007) report no significant association between the cognitive ability tests and the average grading in the last school certificate in the pretests. However, this may be due to the fact that this average has not been conditioned on the level of secondary school. After all, obtaining a good grade from a lower secondary school is definitely not the same as a good grade from a high school. Yet, even if conditioned on the level of secondary school, the average grade shows no correlation with either of the cognitive ability measures. This is somewhat puzzling, but may simply point to a non-linear relationship between them. It could also be that the average school grade reflects something beyond what the concepts of cognitive ability underlying the SCT or WFT measure.

No matter how we interpret the average school grade - as an alternative or supplementary measure of cognitive ability, or simply as reflecting differences in adaptability, diligence, discipline or whatever affects school performance - using it in our estimations contributes to our analysis in two ways. The average school grade clearly affects the range of choice of post-school qualifications and thus accounts for the endogenous selection into post-school tracks. Moreover, in affecting post-school educational choice it may also influence occupational choice and, consequently, wages. Finally, if conditioned on the level of secondary school, the average grade may be particularly suited to account for the heterogeneity in the returns to school qualifications, since grades may also serve as a "quality" signal to employers.

\section{Issues related to estimation}

It is assumed that both education and wages are associated with parental background and cognitive ability. If there is a positive correlation between education and family background as well as cognitive ability, omission of the former two from the regression would lead to an upward bias of the qualification coefficients. In terms of the augmented Mincer-type wage equation introduced earlier this problem can be represented as follows:

$\ln w_{i t}=\beta_{1}^{\prime} S Q_{i t}+\beta_{2}^{\prime} P S Q_{i t}+\theta^{\prime} X_{i t}+\delta^{\prime} X_{i}+u_{i}+\varepsilon_{i t}$

(Unobserved) individual-specific effects are summarized in $u_{i}$. Indicators of cognitive ability and family background are measures of these individual-specific effects. So far these have not been 
jointly studied in a German context. ${ }^{36}$ Since $u_{i}$ is correlated with both $S Q_{i t}$ and $P S Q_{i t}$, omitting them would violate the zero-conditional-mean assumption and thus produce inconsistent estimates of the returns to qualifications.

In following Dearden et al. (2002) and Dearden (1999), it is assumed that once cognitive ability, grades and family background are controlled for, our model is sufficiently and well specified to produce unbiased estimates of the returns to qualifications. The model can then be estimated by pooled OLS.

The return estimates may still be biased if our sample is not representative of the underlying population of both employed and not employed individuals. In fact, SOEP respondents enter our samples only if their wage is observed and the latter is conditional on individuals' status of being employed. Baum (2006, pp. 268) refers to this problem as incidental truncation and states that OLS produces inconsistent estimates if the error processes of the wage and participation equations are correlated, i.e. there must be some unobserved factor driving both participation in the labor force and wages. It was argued before that our wage equation model is sufficiently specified in that it accounts for individual-specific heterogeneity. Similarly, parental background and cognitive ability supposedly drive individuals' employability and, consequently their labor force participation in addition to the more common determinants such as education, gender, marital status etc. Therefore, it does not seem unfounded to assume that given the specifics of our model, a correction for composition or sample selection bias is not necessary. Moreover, the statistical correction for this type of bias using the Heckman selection model requires an exclusion restriction, i.e. one or more factors thought to affect employment participation, but not wages. The choice of factor(s) is however not undisputed. In fact, Heineck \& Anger (2010, p. 539) use father's and mother's education as exclusion restrictions and propose father's occupational position as an alternative. In contrast, we use these variables in our wage equation exactly because of their assumed direct impact on wages. In addition, having children may qualify as an exclusion restriction. However, this may not equally apply to women and men. Moreover, having children may itself be endogenous thus jeopardizing its validity (Heineck \& Anger, 2010; Dearden, 1999).

\footnotetext{
${ }^{36}$ Remember that the cognitive ability test results have become available only in 2006 . The grade information was introduced a little earlier, in 2000. In contrast, the family background variables are available since the first wave of the SOEP in 1984 (Desktop Companion to the German Socio-economic Panel, 2005). To our knowledge the SOEP is the only German micro-dataset which contains measures of cognitive ability.
} 


\section{$5 \quad$ RESULTS}

\section{Pooled OLS}

The pooled OLS regression results are summarized in TABLE $3{ }^{37}$ The presentation is restricted to the education variables and the sets of variables which control for ability and family background bias. In particular, we are interested in how the returns to post-school qualifications react to the inclusion of the sets of indicators of cognitive ability and family background as well as school qualifications. Estimates of the impact of the more commonly employed covariates employed are presented in TABLE A3 in the appendix and will not be discussed further in the paper. $^{38}$

Model 1 in TABLE 3 is the baseline model, which neither controls for school qualifications nor the endogeneity of educational attainment. The coefficients of the returns to post-school qualifications are all highly statistically significant. The size of the coefficients rises with the level of education. Expressed in per cent, the wage premium to obtaining an academic degree is 71.2 per cent and almost 8 times higher than the return to apprenticeship training $(9.7$ per cent $) .{ }^{39}$

Once cognitive ability and family background bias are controlled for (Model 1a), the coefficients of the post-school qualification variables all decrease. In absolute terms, this decrease is most pronounced for university graduates. A comparison of the coefficients of Models 1 and 1a, converted to per-cent premiums, reveals that the positive bias is between 1.9 (apprenticeships) and 7.3 (university education) percentage points and thus non-negligible. Accordingly, the biases correspond to about 10 (university) to 20 per cent (apprenticeships) of the total premiums. Therefore, given the evidence it is necessary to control for ability and family background bias.

The separate impact of the indicators is rather mixed. The test scores do not behave as expected, since only the WFT scores have a positive though small impact on wages. The missing grade variable has a pronounced negative impact and may thus reflect that item non-response is related to weak performance. Some of the family background dummies are significant and important in size, however sometimes behave contrary to what we would expect. For example, the fact that mothers have a high occupational position adversely affects their children's wage prospects.

Model 2 is the baseline model with additional controls for school qualifications. The returns to school qualifications are all statistically significant at the one-per-cent level and are important in size. The high school coefficient is almost as high as the university coefficient. In fact, controlling

\footnotetext{
37 We abstain from comparing our estimates with those in the German studies reviewed, since our choice of school and post-school qualifications and the resulting composition of the education variables are rather different from those in previous studies on the returns to qualifications in Germany.

38 Most of them show the expected sign and are highly statistically significant.

39 In a qualification-based approach, the coefficients cannot be directly interpreted. They have to be converted as follows: $\% \Delta$ wage $\approx 100 *\left(\mathrm{e}^{\beta}-1\right)$.
} 
for school qualifications considerably decreases the coefficients of intermediate higher level postschool qualifications, while the basic and further vocational education estimates are not much affected. This decrease is much more pronounced in the move from Model 1 to Model 2 than from Model 1 to Model 1a, showing the large degree of interdependence between school and post-school qualifications.

Finally, Model 2a represents the full specification. Here account is taken of differences in schooling, cognitive ability and family background. Interestingly, once school qualifications are controlled for, the coefficients of both school and post-school qualifications react only slightly to the inclusion of ability and family background (move from Model 2 to 2a). Still, with respect to post-school qualifications there remains a positive bias for all levels of qualifications, in the order of 0.6 to 1.7 percentage points. However, the evidence is mixed as regards school qualifications, because inclusion of ability and family background raises the high school coefficient.

\section{TABLE 3 POOLED OLS REGRESSION RESULTS - EDUCATION AND} COGNITIVE ABILITY

\begin{tabular}{|c|c|c|c|c|}
\hline & Model 1 & Model 1a & Model 2 & Model 2a \\
\hline \multicolumn{5}{|c|}{ SCHOOL QUALIFICATION (default category: no or secondary general school leaving certificate) } \\
\hline intermediate (Realschule) & & & $\begin{array}{l}.138^{* * *} \\
(.015)\end{array}$ & $\begin{array}{l}.132^{* * *} \\
(.016)\end{array}$ \\
\hline $\begin{array}{l}\text { technical college entrance certificate } \\
\text { (Fachbochschulreife) }\end{array}$ & & & $\begin{array}{l}.219 * * * \\
.029)\end{array}$ & $\begin{array}{l}.203^{* * *} \\
(.029)\end{array}$ \\
\hline high school (Abitur) & & & $\begin{array}{l}.285 * * * \\
(.025)\end{array}$ & $\begin{array}{l}.305 * * * \\
(.271)\end{array}$ \\
\hline \multicolumn{5}{|c|}{ POST-SCHOOL QUALIFICATION (default category: no post-school qualification) } \\
\hline apprenticeship (duale Ausbildung) & $\begin{array}{l}.062 * * * \\
(.027)\end{array}$ & $\begin{array}{l}.048^{* * *} \\
(.028)\end{array}$ & $\begin{array}{l}.051 * * * \\
(.025)\end{array}$ & $\begin{array}{l}.048^{* * *} \\
(.027)\end{array}$ \\
\hline full-time vocational school (Berufffachschule) & $\begin{array}{l}.122 * * * \\
(.031)\end{array}$ & $\begin{array}{l}.101 * * * \\
(.032)\end{array}$ & $\begin{array}{l}.105 * * * \\
(.030)\end{array}$ & $\begin{array}{l}.103^{* * *} \\
(.031)\end{array}$ \\
\hline specialized school (Fachschule) & $\begin{array}{l}.214^{* * *} \\
(.032)\end{array}$ & $\begin{array}{l}.178^{* * *} \\
(.033)\end{array}$ & $\begin{array}{l}.172 * * * \\
(.032)\end{array}$ & $\begin{array}{l}.158^{* * *} \\
(.033)\end{array}$ \\
\hline technical college (Fachhochschule) & $\begin{array}{l}.408^{* * *} \\
(.033)\end{array}$ & $\begin{array}{l}.362 * * * \\
(.036)\end{array}$ & $\begin{array}{l}.253^{* * *} \\
(.034)\end{array}$ & $\begin{array}{l}.248^{* * *} \\
(.036)\end{array}$ \\
\hline university (Universität, Hocbscbule) & $\begin{array}{l}.512^{* * *} \\
(.036)\end{array}$ & $\begin{array}{l}.460 * * * \\
(.039)\end{array}$ & $\begin{array}{l}.325 * * * \\
(.040)\end{array}$ & $\begin{array}{l}.314^{* * *} \\
(.040)\end{array}$ \\
\hline \multicolumn{5}{|l|}{ COGNITIVE ABILITY } \\
\hline word fluency test (WFT) & & $\begin{array}{l}.002 * * \\
(.001)\end{array}$ & & $\begin{array}{l}.002 * * \\
(.001)\end{array}$ \\
\hline WFT miss & & $\begin{array}{l}.053 \\
(.045)\end{array}$ & & $\begin{array}{l}0.043 \\
(.048)\end{array}$ \\
\hline symbol correspondence test (SCT) & & $\begin{array}{l}.001 \\
(.001)\end{array}$ & & $\begin{array}{l}.000 \\
(.001)\end{array}$ \\
\hline SCT miss & & $\begin{array}{l}.016 \\
(.045)\end{array}$ & & $\begin{array}{l}.030 \\
(.048)\end{array}$ \\
\hline average grade & & $\begin{array}{l}-.004 \\
(.011)\end{array}$ & & $\begin{array}{l}.005 \\
(.011)\end{array}$ \\
\hline grade miss & & $\begin{array}{l}-.065^{* * *} \\
-.019)\end{array}$ & & $\begin{array}{l}(.011) \\
-.035^{*} \\
(.019)\end{array}$ \\
\hline $\mathrm{N}$ & 6,994 & 6,994 & 6,994 & 6,994 \\
\hline $\mathrm{R}^{2}$ & 0.400 & 0.395 & 0.393 & 0.389 \\
\hline
\end{tabular}

Note: robust standard errors in parantheses (automatically computed and reported with p-weighted data); significance levels $*<.10, * *<.05, * * *<.01$.

Source: Socio-economic Panel (SOEP) (2010), own calculations. 
TABLE 4 POOLED OLS REGRESSION RESULTS - FAMILY BACKGROUND VARIABLES (TABLE 3 ctd.)

\begin{tabular}{|c|c|c|c|c|}
\hline & Model 1 & Model 1a & Model 2 & Model 2a \\
\hline \multicolumn{5}{|c|}{ FATHER'S EDUCATION (default category: no post-school qualification) } \\
\hline \multicolumn{2}{|l|}{ basic vocational } & $\begin{array}{l}.015 \\
(.024)\end{array}$ & & $\begin{array}{l}.004 \\
(.023)\end{array}$ \\
\hline \multicolumn{2}{|l|}{ specialized school } & $\begin{array}{l}.150^{* *} \\
(.061)\end{array}$ & & $\begin{array}{l}.152^{* *} \\
(.063)\end{array}$ \\
\hline \multicolumn{2}{|l|}{ civil service } & $\begin{array}{l}.082 \\
(.079)\end{array}$ & & $\begin{array}{l}.112 \\
(.081)\end{array}$ \\
\hline \multicolumn{2}{|l|}{ higher education } & $\begin{array}{l}.066^{*} \\
(.040)\end{array}$ & & $\begin{array}{l}.057 \\
(.039)\end{array}$ \\
\hline \multicolumn{2}{|l|}{ missing } & $\begin{array}{l}-.005 \\
(.031)\end{array}$ & & $\begin{array}{l}-.003 \\
(.031)\end{array}$ \\
\hline \multicolumn{5}{|c|}{ MOTHER'S EDUCATION (default category: no post-school qualification) } \\
\hline \multicolumn{2}{|c|}{ basic vocational } & $\begin{array}{l}.007 \\
(.016)\end{array}$ & & $\begin{array}{l}-.006 \\
(.016)\end{array}$ \\
\hline \multicolumn{2}{|l|}{ specialized school } & $\begin{array}{l}.329 * * * \\
(.063)\end{array}$ & & $\begin{array}{l}.291 * * \\
(.063)\end{array}$ \\
\hline \multicolumn{2}{|l|}{ higher education } & $\begin{array}{l}-.057 \\
(.050)\end{array}$ & & $\begin{array}{l}-.092^{*} \\
(.050)\end{array}$ \\
\hline \multicolumn{2}{|l|}{ missing } & $\begin{array}{l}-.035 \\
(.023)\end{array}$ & & $\begin{array}{l}-.028 \\
(.023)\end{array}$ \\
\hline \multicolumn{5}{|c|}{ FATHER'S OCCUPATIONAL POSITION (default category: not employed, other, missing) } \\
\hline \multicolumn{2}{|c|}{ farmer } & $\begin{array}{l}-.096^{* *} \\
(.042)\end{array}$ & & $\begin{array}{l}-.073^{*} \\
(.041)\end{array}$ \\
\hline \multicolumn{2}{|l|}{ worker } & $\begin{array}{l}-.041^{*} \\
(.022)\end{array}$ & & $\begin{array}{l}-.003 \\
(.031)\end{array}$ \\
\hline \multicolumn{2}{|l|}{ employee } & $\begin{array}{l}-.030 \\
(.032)\end{array}$ & & $\begin{array}{l}.003 \\
(.031)\end{array}$ \\
\hline & $\begin{array}{l}-.023 \\
(.024)\end{array}$ & & $\begin{array}{l}-.013 \\
(.023)\end{array}$ \\
\hline \multirow{2}{*}{\multicolumn{2}{|c|}{ senior manager }} & .044 & & .031 \\
\hline & & $(.029)$ & & $(.028)$ \\
\hline \multicolumn{2}{|l|}{ self-employed } & $\begin{array}{l}-.024 \\
(.031)\end{array}$ & & $\begin{array}{l}-.023 \\
(.031)\end{array}$ \\
\hline \multicolumn{5}{|c|}{ MOTHER'S OCCUPATIONAL POSITION (default category: not employed, other, missing) } \\
\hline \multicolumn{2}{|c|}{ farmer } & $\begin{array}{l}.098^{*} \\
(.056)\end{array}$ & & $\begin{array}{l}.082 \\
(.055)\end{array}$ \\
\hline \multicolumn{2}{|l|}{ worker } & $\begin{array}{l}-.090^{* * *} \\
(.017)\end{array}$ & & $\begin{array}{l}-.078 * * * \\
(.017)\end{array}$ \\
\hline \multicolumn{2}{|l|}{ employee } & $\begin{array}{l}.003 \\
(.034)\end{array}$ & & $\begin{array}{l}.010 \\
(.036)\end{array}$ \\
\hline \multicolumn{2}{|l|}{ middle manager } & $\begin{array}{l}-.076^{* * *} \\
(.016)\end{array}$ & & $\begin{array}{l}-.073 * * * \\
(.016)\end{array}$ \\
\hline \multicolumn{2}{|l|}{ senior manager } & $\begin{array}{l}-.246^{* * *} \\
(.073)\end{array}$ & & $\begin{array}{l}-.205 * * * \\
(.073)\end{array}$ \\
\hline \multicolumn{2}{|l|}{ self-employed } & $\begin{array}{l}-.031 \\
(.035)\end{array}$ & & $\begin{array}{l}-.042 \\
(.034)\end{array}$ \\
\hline \multicolumn{5}{|c|}{ PARENTS SHOWED INTEREST IN CHILD'S SCHOOL PERFORMANCE (default category: not at all) } \\
\hline \multicolumn{2}{|c|}{ very much } & $\begin{array}{l}0.003 \\
(.028)\end{array}$ & & $\begin{array}{l}-0.009 \\
(.029)\end{array}$ \\
\hline quite a lot & & 0.014 & & $\begin{array}{l}0.013 \\
(.026)\end{array}$ \\
\hline & & 0.006 & & 0.011 \\
\hline not a lot & & $(.026)$ & & $(.026)$ \\
\hline missing & & $\begin{array}{l}-.003 \\
(.097)\end{array}$ & & $\begin{array}{l}0.061 \\
(.094)\end{array}$ \\
\hline $\mathrm{N}$ & 6,994 & 6,994 & 6,994 & 6,994 \\
\hline $\mathrm{R}^{2}$ & 0.400 & 0.395 & 0.393 & 0.389 \\
\hline
\end{tabular}

Note: robust standard errors in parantheses (automatically computed and reported with p-weighted data); significance levels $*<.10, * *<.05, * * *<.01$

Source: Socio-economic Panel (SOEP) (2010), own calculations. 
Overall, premiums to complete educational paths seem to be largely driven by the return to school qualifications. In fact, the school qualification premiums by far exceed the premiums associated with basic and intermediate vocational education. Moreover, higher level school qualifications are particularly important in determining individuals' overall wage prospects.

\section{Heterogeneity in returns to qualifications}

Finally, aspects of heterogeneity in the returns to education with respect to the three measures of cognitive ability are considered. Joint linear effects can be analyzed via the inclusion of interaction terms between the education variables and the ability measures. Moreover, the impact of the cognitive ability measures may differ across their distributions at a specific level of schooling. In order to account for such non-linearities, dummy variables can be employed which indicate whether individuals belong in the top or bottom 25 per cent of the ability measure distribution, conditional on schooling type. Separate analyses were made for the grade and cognitive ability test measures which are summarized in TABLES 5 and 6, respectively.

Since the average grade measure refers to the last school certificate, the analysis is restricted to school qualifications. Model 3 in TABLE 5 shows how the inclusion of the interaction terms affects the returns to school qualifications. While the return to intermediate schooling declines and turns insignificant, the coefficients of higher level schooling increase and remain statistically significant. The main grade effect remains insignificant, while the interaction of the grade measure with the variable high school delivers a significantly positive effect.

The analysis of non-linear grade effects on the returns to school qualifications conveys even more differentiated insights (Model 4). Only the measures for high school graduates are statistically significant and positive. However, the coefficient which indicates that individuals are in the top 25 per cent of the grade distribution is twice as high than the one indicating whether one is in the bottom 25 per cent. Thus, non-linear effects seem to better explain heterogeneous returns to school qualifications. Having a high school certificate pays off irrespective of individuals' grading, though belonging in the top 25 per cent of the grade distribution is rewarded the most.

The analysis of the cognitive ability tests is far less conclusive (TABLE 6). The interaction effects are significant and negative for the word fluency test and post-school qualifications, except apprenticeships. However, the coefficients are rather small and almost equivalent in size. Moreover, their impact seems to just compensate the positive main effect. The analysis of nonlinearities is even more puzzling. Only few coefficients are statistically significant. Mostly, they are opposite to what one would usually expect both with respect to the direction of the impact and 
which ability group is affected. Interestingly though, the impact of the SCT and SCT missing variables turn significant in Model 4 as compared to Model 2a.

TABLE 5 RETURNS TO SCHOOL QUALIFICATIONS AND AVERAGE GRADING - ASPECTS OF HETEROGENEITY

\begin{tabular}{|c|c|c|c|}
\hline & \multicolumn{3}{|c|}{ Pooled Sample } \\
\hline & Model 2a & Model 3 & Model 4 \\
\hline \multicolumn{4}{|c|}{ SCHOOL QUALIFICATION (default category: no or secondary general school leaving certificate) } \\
\hline intermediate (Realscbule) & $\begin{array}{l}.132 * * * \\
(.016)\end{array}$ & $\begin{array}{l}.061 \\
(.081)\end{array}$ & $\begin{array}{l}.128^{* * *} \\
(.017)\end{array}$ \\
\hline \multirow{2}{*}{$\begin{array}{r}\text { technical college entrance certificate } \\
\text { (Facbbocbscbulreife) }\end{array}$} & $.203^{* * *}$ & $.287 * *$ & $.226^{* * *}$ \\
\hline & $(.029)$ & $(.111)$ & $(.039)$ \\
\hline high school (Abitur/Hocbscbulreife) & $\begin{array}{l}.305^{* * *} \\
(.271)\end{array}$ & $\begin{array}{l}.405 * * * \\
(.074)\end{array}$ & $\begin{array}{l}.244^{* * *} \\
(.028)\end{array}$ \\
\hline \multicolumn{4}{|c|}{ POST-SCHOOL QUALIFICATION (default category: no post-school qualification) } \\
\hline apprenticeship (duale Ausbildung) & $\begin{array}{l}.048^{* * *} \\
(.027)\end{array}$ & $\begin{array}{l}.047^{*} \\
(.027)\end{array}$ & $\begin{array}{l}.053 * * \\
(.027)\end{array}$ \\
\hline full-time vocational school (Beruffacbschule) & $\begin{array}{l}.103^{* * *} \\
(.031)\end{array}$ & $\begin{array}{l}.101 * * * \\
(.031)\end{array}$ & $\begin{array}{l}.107 * * * \\
(.031)\end{array}$ \\
\hline specialized school (Fachscbule) & $\begin{array}{l}.158^{* * *} \\
(.033)\end{array}$ & $\begin{array}{l}.160^{* * *} \\
(.033)\end{array}$ & $\begin{array}{l}.164^{* * *} \\
(.033)\end{array}$ \\
\hline technical college (Fachhochschule) & $\begin{array}{l}.248^{* * *} \\
(.036)\end{array}$ & $\begin{array}{l}.245^{* * *} \\
(.036)\end{array}$ & $\begin{array}{l}.253^{* * *} \\
(.036)\end{array}$ \\
\hline university (Universität, Hocbschule) & $\begin{array}{l}.314^{* * *} \\
(.040)\end{array}$ & $\begin{array}{l}.303^{* * *} \\
(.040)\end{array}$ & $\begin{array}{l}.309 * * * \\
(.040)\end{array}$ \\
\hline \multicolumn{4}{|l|}{ COGNITIVE ABILITY } \\
\hline grade miss & $\begin{array}{l}.005 \\
(.011) \\
-.035^{*} \\
(.019)\end{array}$ & $\begin{array}{l}.011 \\
(.015) \\
-.032 * \\
(.019)\end{array}$ & $\begin{array}{l}.014 \\
(.014) \\
.034^{*} \\
(.019)\end{array}$ \\
\hline \multicolumn{4}{|l|}{ HETEROGENEITY IN RETURNS } \\
\hline \multicolumn{2}{|l|}{ intermediate* average grade } & $\begin{array}{l}.027 \\
(.027)\end{array}$ & \\
\hline technical college entrance certificate*average grade & & $\begin{array}{l}-.030 \\
(.039) \\
.051 * * \\
(.024)\end{array}$ & \\
\hline intermediate*average grade top $25 \%$ & & & $\begin{array}{l}.019 \\
(.033)\end{array}$ \\
\hline intermediate*average grade bottom $25 \%$ & & & $\begin{array}{l}.010 \\
(.025)\end{array}$ \\
\hline $\begin{array}{r}\text { technical college entrance certificate* } \\
\text { average grade top25\% }\end{array}$ & & & $\begin{array}{l}-.046 \\
(.060)\end{array}$ \\
\hline \multirow{2}{*}{$\begin{array}{r}\text { technical college entrance certificate* } \\
\text { average grade bottom } 25 \%\end{array}$} & & & -.051 \\
\hline & & & $\begin{array}{l}(.047) \\
.149 * * *\end{array}$ \\
\hline high school*average grade top $25 \%$ & & & $(.041)$ \\
\hline high school*average grade bottom $25 \%$ & & & $\begin{array}{l}.070^{* *} \\
(.034) \\
\end{array}$ \\
\hline $\mathrm{N}$ & 6,994 & 6,994 & 6,994 \\
\hline $\mathrm{R}^{2}$ & 0.389 & 0.389 & 0.388 \\
\hline
\end{tabular}

Note: robust standard errors in parantheses (automatically computed and reported with p-weighted data); significance levels $*<.10, * *<.05, * *<.01$.

Source: Socio-economic Panel (SOEP) (2010), own calculations. 


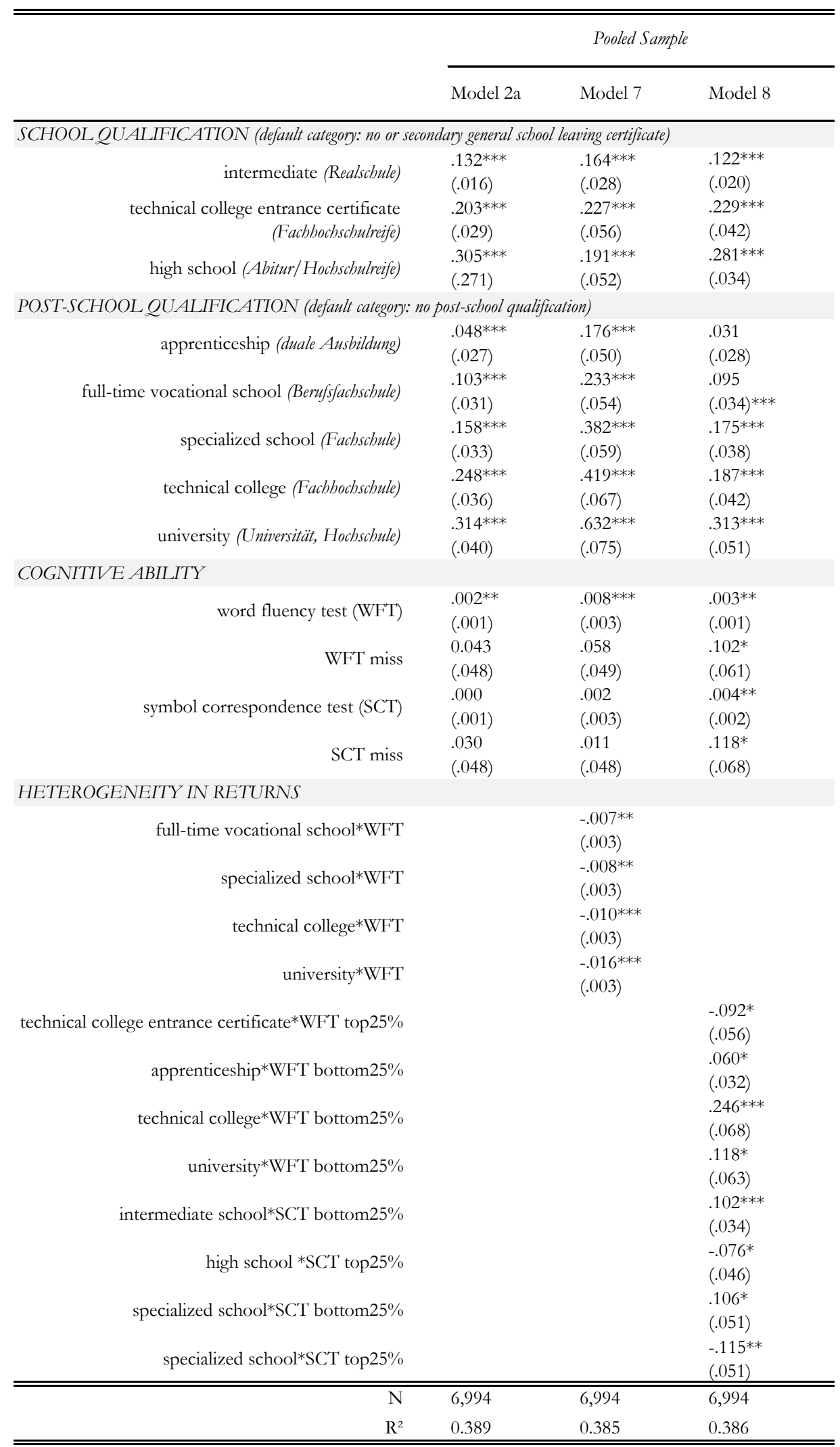

Note: robust standard errors in parantheses (automatically computed and reported with p-weighted data); significance levels $*<.10, * *<.05, * * *<.01$; for reasons of space heterogeneity coefficients reported only if statistically significant in either of the specifications.

Source: Socio-economic Panel (SOEP) (2010), own calculations. 


\section{CONCLUSION}

Empirical models of the returns to education should reflect a country's specific structure of the educational system and the determinants of educational choice and outcomes. Moreover, the estimated returns should be unbiased. Only then can such analyses qualify for policy suggestions or human capital investment decisions. Early tracking, parental influence in determining children's secondary school track, interdependencies between secondary school and post-school achievement are specifics of the German system of education which require proper integration into an analysis of the returns to education in Germany. Therefore, it was not only suggested to consider treatment heterogeneity instead of the dominant years-of-schooling approach, in particular, the separation of school and post-school qualifications, but also to account for the endogeneity of education based on parental background. In addition, we controlled for potential ability bias in the return estimates.

We used 10 pooled cross-sections from the latest distribution of the German SOEP (SOEP v26) to estimate wage premiums to school and post-school qualifications in Germany. To account for potential family background bias, parents' education, parents' occupational position and parents' interest in their child's school performance were used. Two types of indicators of individuals' cognitive ability were employed, an average of individuals' school grades and results from two ultra-short cognitive ability tests. The data were estimated by pooled OLS, since the underlying empirical model was assumed to be sufficiently well specified to produce unbiased estimates of the returns to qualifications.

We find that post-school qualification-specific wage premiums are upward biased in the order of 10 to 20 per cent of the total premiums if no account is taken of cognitive ability and family background information. However, the inclusion of school qualifications reduces this bias considerably. In fact, higher level post-school qualifications react much more strongly to the inclusion of school qualifications than to the inclusion of the ability and parental background indicators which suggests a strong interdependence between school and post-school qualifications.

Moreover, the returns to school qualifications are significant and differ substantially between levels of school qualifications. In fact, the schooling coefficients by far exceed the returns to apprenticeships and higher level schooling seems even more important than intermediate postschool qualifications in terms of its economic return. Therefore, school qualifications, in particular higher level schooling, are much more important in driving individuals' overall education-related wage prospects than most post-school qualifications. 
Ammermüller, A.; Weber, A. M. (2005), Educational attainment and returns to education in Germany - an analysis by subject of degree, gender and region, Centre for European Economic Research, ZEW Discussion Paper, No. 05-17.

Anger, S.; Heineck, G. (2010), Cognitive abilities and earnings - first evidence for Germany. Applied Economics Letters, 17, 699-702.

Anger, S.; Lupo, K. (2007); Bildungsrenditen von Vollzeitbeschäftigten in Deutschland: Der Osten hat aufgeholt, German Institute for Economic Research, DIW Wochenbericht, No. 10/2007, pp. 149-157.

Baethge, M.; Solga, H.; Wieck, M. (2007), Berufsbildung im Umbruch: Signale eines überfälligen Aufbruchs, Studie: Friedrich-Ebert-Stiftung, Bonn, electronic edition: http://library.fes.de/pdffiles/stabsabteilung/04258/

Baum, C. F. (2006), An introduction to modern econometrics using Stata, Stata Press, College Station, Texas.

Becker, G. S. (1975), Human capital - A theoretical and empirical analysis, with special reference to education, New York: National Bureau of Economic Research, $2^{\text {nd }}$ ed.

Blundell, R.; Dearden, L.; Sianesi, B. (2005), Evaluating the effect of education on earnings: models, methods and results from the National Child Development Survey, Journal of the Royal Statistical Society, 168(3), pp. 473-512.

Card, D. (2001), Estimating the return to schooling: progress on some persistent econometric problems, Econometrica, 69(5), pp. 1127-60.

Card, D. (1999), The causal effect of education on earnings, in: Ashenfelter, O.; Card, D. (ed.), Handbook of Labor Economics, Volume 3A, Elsevier Science, Amsterdam et al., pp. 1801-1863.

Dearden, L. (1999), Qualifications and earnings in Britain: how reliable are conventional OLS estimates of the returns to education?, Institute for Fiscal Studies, Working Paper Series, No. W99/7.

Dearden, L.; McIntosh, S. et al. (2002), The returns to academic and vocational qualifications in Britain, Bulletin of Economic Research, 54(3), pp. 249-274.

Desktop Companion to the German Socio-economic Panel (SOEP) (2005), edited by: HaiskenDeNew, J.; Frick, J. R., Version 8.0, Dec 2005.

Dustmann, C. (2004), Parental background, secondary school track choice, and wages, Oxford Economic Papers, 56(2), pp. 209-230. 
Flossmann, A. L.; Pohlmeier, W. (2006), Causal returns to education: a survey on empirical evidence for Germany, Jahrbücher für Nationalökonomie und Statistik, 226(1), pp. 6-23.

Griliches, Z. (1977), Estimating the Returns to Schooling: Some Econometric Problems, Econometrica, 45(1), pp. 1-22.

Heineck, G.; Anger, S. (2010), The returns to cognitive abilities and personality traits in Germany, Labour Economics, 17(3), pp. 535-546.

Lang, F. R.; Weiss, D. et al. (2007), Assessing cognitive capacities in computer-assisted survey research: two ultra-short tests for intellectual ability in the German Socio-Economic Panel (SOEP), Schmollers Jabrbuch, 127(1), pp. 183-192.

Lauer, C. (2003), Family background, cohort and education: A French-German comparison based on a multivariate ordered probit model of educational attainment, Labour Economics, 10(2), pp. 231-251.

Lauer, C.; Steiner, V. (2000), Returns to education in West Germany - An empirical assessment, Center for European Economic Research, ZEW Discussion Paper Series, No. 00-04.

Lauer, C.; Steiner, V. (1999), Returns to human capital in Germany: review of the empirical literature, in: Asplund, R.; Pereira, P.T. (ed.), Returns to buman capital in Europe: a literature review, ETLA, The Research Institute of the Finnish Economy, Helsinki, pp. 125-145.

Mincer, J. (1974), Schooling, experience, and earnings, New York: National Bureau of Economic Research.

Ruf, M. (2008), Der Übergang von der vollzeitschulischen Berufsausbildung in das Beschäftigungssystem als Herausforderung für die Berufsbildungsforschung: theoretische und empirische Zugänge zum Problem der Akzeptanz vollzeitschulisch erworbener Berufsabschlüsse, Dissertation, Konstanz, electronic edition:

http://www.ub.uni-konstanz.de/kops/volltexte/2008/4854/

Schupp, J.; Herrmann, S. et al. (2008), Erfassung kognitiver Leistungspotentiale Erwachsener im Sozio-oekonomischen Panel (SOEP), German Institute for Economic Research, DIW Data Documentation, 32 .

Skarupke, R. (2005), Renditen von Bildungsinvestitionen - Paneldatenschätzungen für die Bundesrepublik Deutschland. Schriften zur Empirischen Wirtschaftsforschung, Band 6, Peter Lang: Frankfurt a.M. et al.

Spitz-Oener, Alexandra (2006), Technical change, job tasks, and rising educational demands: looking outside the wage structure, Journal of Labor Economics, 24(2), pp. 235-270. 
APPENDIX 
TABLE A1 COMPOSITION OF EDUCATION CATEGORIES IN REVIEWED GERMAN-BASED LITERATURE

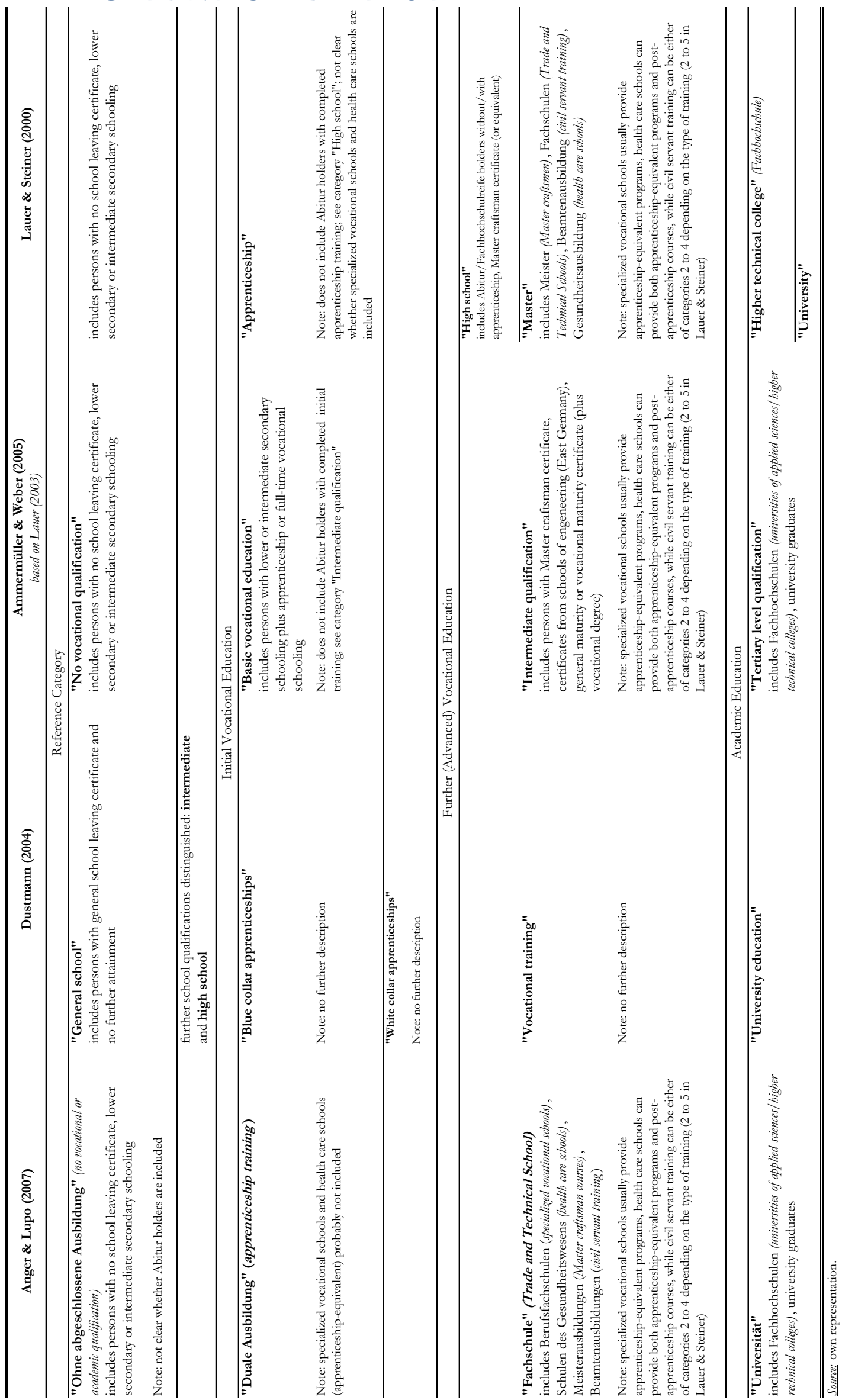


TABLE A2 DESCRIPTIVE STATISTICS (TABLE $1 \mathrm{ctd}$.

\begin{tabular}{|c|c|c|c|c|c|}
\hline \multirow[b]{2}{*}{ Variables } & & \multicolumn{4}{|c|}{$\begin{array}{l}\text { Pooled Sample } \\
(\mathrm{N}=6,994)\end{array}$} \\
\hline & & Mean & S.D. & Min & Max \\
\hline \multicolumn{6}{|l|}{ Wage } \\
\hline & hourly wage & 15.23 & 8.59 & 0.90 & 172.62 \\
\hline & log hourly wage & 2.61 & 0.49 & -0.10 & 5.15 \\
\hline \multicolumn{6}{|c|}{ Socio-economic indicators } \\
\hline & female & 0.43 & 0.49 & 0 & 1 \\
\hline & migration background & 0.05 & 0.23 & 0 & 1 \\
\hline & married and/or living with partner status & 0.67 & 0.47 & 0 & 1 \\
\hline & recognized disability & 0.06 & 0.24 & 0 & 1 \\
\hline & living in East Germany & 0.11 & 0.31 & 0 & 1 \\
\hline \multicolumn{6}{|c|}{ Work-related indicators } \\
\hline & work experience & 20.32 & 10.23 & 0 & 49 \\
\hline & work experience squared & 517.71 & 442.29 & 0 & 2401 \\
\hline & working part-time & 0.20 & 0.39 & 0 & 1 \\
\hline & self-employed & 0.07 & 0.26 & 0 & 1 \\
\hline & civil servant & 0.05 & 0.21 & 0 & 1 \\
\hline \multicolumn{6}{|c|}{ Economic sector } \\
\hline & agriculture & 0.02 & 0.13 & 0 & 1 \\
\hline & industry & 0.29 & 0.45 & 0 & 1 \\
\hline & construction & 0.06 & 0.25 & 0 & 1 \\
\hline & banking, insurance & 0.06 & 0.23 & 0 & 1 \\
\hline & other services & 0.33 & 0.47 & 0 & 1 \\
\hline & public administration & 0.24 & 0.43 & 0 & 1 \\
\hline \multicolumn{6}{|l|}{ Firm size } \\
\hline & $<5$ & 0.12 & 0.32 & 0 & 1 \\
\hline & 5 to $<20$ & 0.15 & 0.36 & 0 & 1 \\
\hline & 20 to $<200$ & 0.28 & 0.45 & 0 & 1 \\
\hline & 200 to $<2,000$ & 0.22 & 0.42 & 0 & 1 \\
\hline & $2,000+$ & 0.23 & 0.42 & 0 & 1 \\
\hline \multicolumn{6}{|l|}{$\overline{Y e a r}$} \\
\hline & 2000 & 0.06 & 0.23 & 0 & 1 \\
\hline & 2001 & 0.00 & 0.01 & 0 & 1 \\
\hline & 2002 & 0.07 & 0.26 & 0 & 1 \\
\hline & 2003 & 0.09 & 0.28 & 0 & 1 \\
\hline & 2004 & 0.10 & 0.30 & 0 & 1 \\
\hline & 2005 & 0.11 & 0.32 & 0 & 1 \\
\hline & 2006 & 0.20 & 0.40 & 0 & 1 \\
\hline & 2007 & 0.09 & 0.29 & 0 & 1 \\
\hline & 2008 & 0.12 & 0.33 & 0 & 1 \\
\hline & 2009 & 0.15 & 0.36 & 0 & 1 \\
\hline
\end{tabular}

Source: Socio-economic Panel (SOEP) (2010), own calculations. 
TABLE A3 POOLED OLS REGRESSION ESTIMATES - ADDITIONAL COVARIATES (TABLE 3 ctd.)

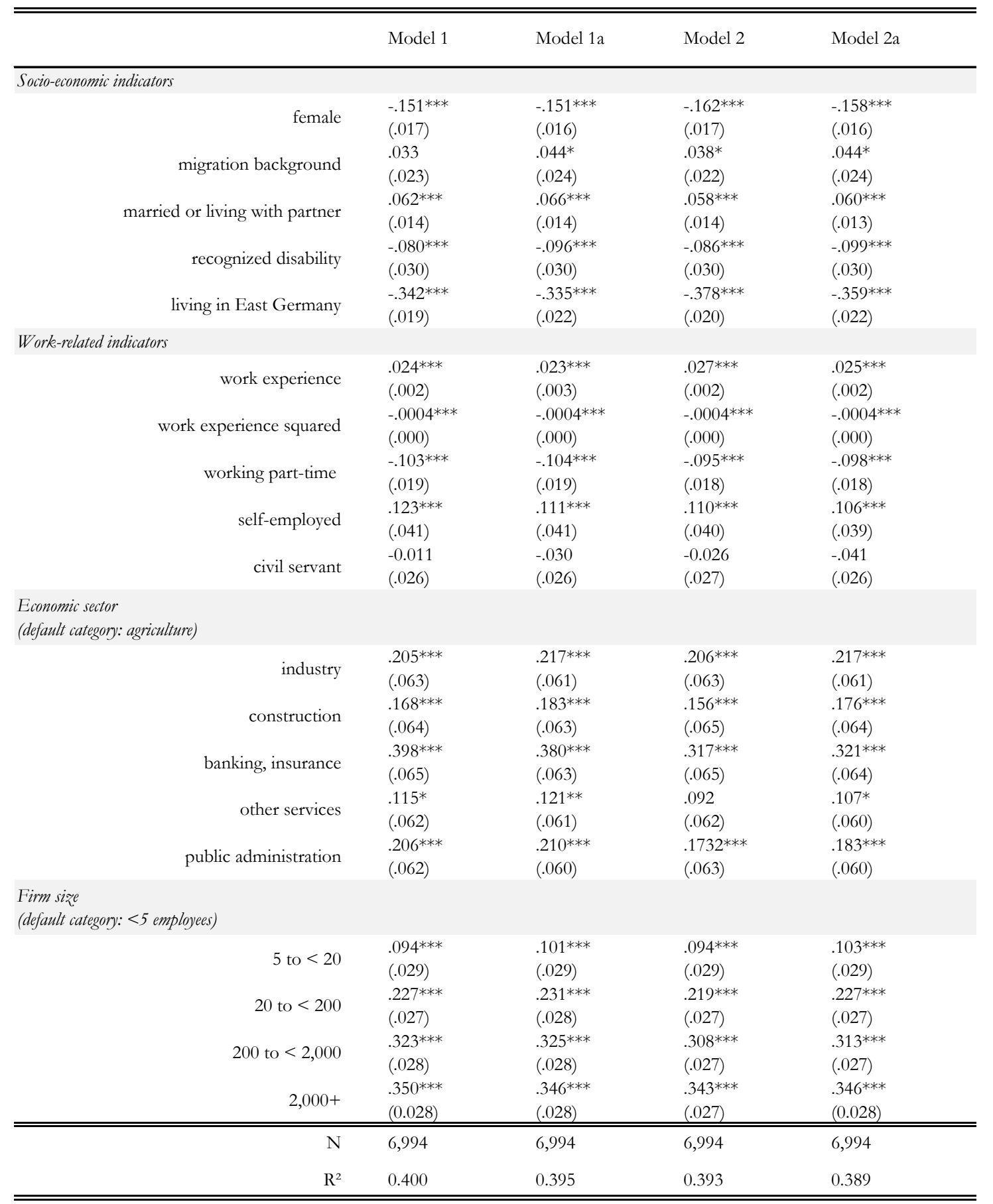

Note: robust standard errors in parantheses (automatically computed and reported with p-weighted data); significance levels $*<.10, * *<.05, * * *<.01$.

Source: Socio-economic Panel (SOEP) (2010), own calculations. 
TABLE A4 POOLED OLS REGRESSION ESTIMATES - ADDITIONAL COVARIATES (TABLE $3 \mathrm{ctd}$.)

\begin{tabular}{|c|c|c|c|c|c|}
\hline & & Model 1 & Model 1a & Model 2 & Model 2a \\
\hline \multicolumn{6}{|l|}{$\begin{array}{l}\text { Year } \\
\text { (default category: year 2000) }\end{array}$} \\
\hline & 2001 & $\begin{array}{l}.073 * * \\
.036)\end{array}$ & $\begin{array}{l}.033 \\
(.043)\end{array}$ & $\begin{array}{l}.060 \\
(.034)^{*}\end{array}$ & $\begin{array}{l}0.018 \\
(.042)\end{array}$ \\
\hline & 2002 & $\begin{array}{l}-.031 \\
(.026)\end{array}$ & $\begin{array}{l}-.029 \\
(.025)\end{array}$ & $\begin{array}{l}-.028 \\
(.026)\end{array}$ & $\begin{array}{l}-.027 \\
(.025)\end{array}$ \\
\hline & 2003 & $\begin{array}{l}-.010 \\
(.027)\end{array}$ & $\begin{array}{l}-.009 \\
(.027)\end{array}$ & $\begin{array}{l}-.010 \\
(.027)\end{array}$ & $\begin{array}{l}-.008 \\
(.027)\end{array}$ \\
\hline & 2004 & $\begin{array}{l}-.007 \\
(.031)\end{array}$ & $\begin{array}{l}-.008 \\
(.030)\end{array}$ & $\begin{array}{l}-.010 \\
(.030)\end{array}$ & $\begin{array}{l}-.010 \\
(.029)\end{array}$ \\
\hline & 2005 & $\begin{array}{l}-.015 \\
(.027)\end{array}$ & $\begin{array}{l}-.020 \\
(.026)\end{array}$ & $\begin{array}{l}-.022 \\
(.026)\end{array}$ & $\begin{array}{l}-.024 \\
(.026)\end{array}$ \\
\hline & 2006 & $\begin{array}{l}-.043 \\
(.023)\end{array}$ & $\begin{array}{l}-0.059 * * * \\
(.023)\end{array}$ & $\begin{array}{l}-0.059 * * \\
(.023)\end{array}$ & $\begin{array}{l}-0.067^{* * *} \\
(.023)\end{array}$ \\
\hline & 2007 & $\begin{array}{l}-0.038 \\
(.026)\end{array}$ & $\begin{array}{l}-0.047^{*} \\
(.026)\end{array}$ & $\begin{array}{l}-0.050 * \\
(.026)\end{array}$ & $\begin{array}{l}-0.053^{* *} \\
(.026)\end{array}$ \\
\hline & 2008 & $\begin{array}{l}-0.026 \\
(.025)\end{array}$ & $\begin{array}{l}-0.042 \\
(.026)\end{array}$ & $\begin{array}{l}-0.041 \\
(.025)\end{array}$ & $\begin{array}{l}-0.049 * \\
(.025)\end{array}$ \\
\hline & 2009 & $\begin{array}{l}-0.040 \\
(.027)\end{array}$ & $\begin{array}{l}-0.054 * * \\
(.026)\end{array}$ & $\begin{array}{l}-0.060^{* *} \\
(.027)\end{array}$ & $\begin{array}{l}-0.065^{* *} \\
(.026)\end{array}$ \\
\hline \multicolumn{6}{|l|}{ Constant } \\
\hline & constant & $\begin{array}{l}1.856^{* * *} \\
(.076) \\
\end{array}$ & $\begin{array}{l}1.868^{* * *} \\
(.092) \\
\end{array}$ & $\begin{array}{l}1.783^{* * *} \\
(.076) \\
\end{array}$ & $\begin{array}{l}1.769 * * * \\
(.091) \\
\end{array}$ \\
\hline & $\mathrm{N}$ & 6,994 & 6,994 & 6,994 & 6,994 \\
\hline & $\mathrm{R}^{2}$ & 0.400 & 0.395 & 0.393 & 0.389 \\
\hline
\end{tabular}

Note: robust standard errors in parantheses (automatically computed and reported with p-weighted data); significance levels $*<.10, * *<.05, * * *<.01$.

Source: Socio-economic Panel (SOEP) (2010), own calculations. 


\section{ECONOMIC RETURNS TO POST- APPRENTICESHIP EDUCATION IN GERMANY - A FIXED EFFECTS APPROACH}

\section{Abstract}

This paper evaluates the wage effects of post-apprenticeship investments in formal qualifications at the vocational and academic levels. Making use of both the longitudinal nature of the data from the German Socio-economic Panel (SOEP) and the variation in individuals' level of education over time, a linear unobserved effects panel data model with fixed effects can be estimated in order to adequately account for the detected endogeneity of the regressors. Overall, there is no significant return to further vocational education, while the returns to university education are significantly positive and sizeable. There are differences in the estimates depending on geographical region, sex and sample composition. Combinations of further vocational and academic education are associated with a strong wage penalty, though the estimates of these interactions are less reliable than the main effects. 
It is widely agreed upon that "life-long learning" has become one of the decisive factors of sustainable economic and social development" ${ }^{\text {41 }}$ (Unabhängige Expertenkommission Finanzierung Lebenslangen Lernens, 2004, p. 9). This conviction arises from the challenges of an internationalized, knowledge-based world economy in which knowledge and technology develop at an increasingly fast pace. An economy's stock of human capital is the key to innovativeness, competiveness and prosperity. However, this stock requires continuous adjustment. The German economy like many other Western economies faces additional challenges with respect to the quantity and quality of its human capital given the consequences resulting from its natural resource scarcity, a rapidly ageing population and imminent skill shortages.

Vital to Germany's skill production is its educational system. The above challenges will not only affect the system's infrastructure and institutions, but also individuals' educational biographies. In this context, recent economic research has focused on the incidence and economic effects of continuous (on-the-job) training. This paper takes the view that closer attention has to be paid to the role of formal qualifications, in particular sequences of post-school qualifications which combine apprenticeship training and further education. Why?

The German apprenticeship system is the most important provider of post-school qualifications in Germany. In fact, basic vocational education (with apprenticeships making up the largest share) is the highest level of post-school qualification for over two thirds of the German population. ${ }^{42}$ In addition, apprenticeships remain very popular among younger cohorts. In 2008 32 per cent of all school leavers started apprenticeship training. ${ }^{43}$

Yet, there is evidence that the skills acquired during apprenticeship training depreciate at an increasingly faster rate, partly due to technological change (Pfeiffer \& Blechinger, 1995). While this may imply that apprenticeships do not adjust sufficiently fast to changing economic requirements, it may also point to an increasing importance of post-apprenticeship investments in higher level post-school qualifications. However, this assumption is only partially confirmed by

\footnotetext{
40 According to the Commission (p. 6), life-long learning “encompasses all types of learning over individuals' lifecycles: formal, non-formal and informal” [translation A.G.].

41 [translation A.G.].

${ }^{42}$ The exact figure is 71.2 per cent. Other qualifications are: further vocational education certificate ( 9.9 per cent), a degree from a technical college (university of applied science, 7 per cent) or a university degree (11.4 per cent). The calculations exclude persons who did not specify their highest level of post-school education or did not (yet) attain any of the given levels of vocational qualification. Shares refer to persons who acquired some post-school education. The data refer to the year 2008 (Autorengruppe Bildungsberichterstattung, 2010).

${ }^{43}$ Within the system of initial vocational education another 10 per cent started full-time vocational schooling or civil service training. Other paths followed were: academic studies (11 per cent), attending another general or vocational school (10 per cent) or a full-time vocational school in the framework of the transitory system (11 per cent). Another 20 per cent were working, entered the military/community service or took a gap year, while the rest were unemployed or not working (4 per cent) (Bundesinstitut für Berufsbildung, 2009).
} 
the facts. Post-apprenticeship university education has become increasingly important in e.g. German banking (Finegold \& Wagner, 2002). In contrast, investments in post-apprenticeship qualifications in traditional production (foremen) and craft occupations (Master craftspersons) have considerably declined (Müller, 2006; Plicht, 2000).

Recently the Federal Government has adjusted and expanded existing incentive schemes ${ }^{44}$ to attract more persons into post-initial education programs at the vocational level, maybe to counteract the observed negative trend. In addition, a scholarship program has been initiated for exceptionally talented, vocationally trained persons who opt for academic education. Besides its perceived economic necessity, the initiative also aims at breaking the remaining strong association between individuals' labor market outcomes and family background and thus at increasing individuals' social mobility.

Politically, sequences of post-school qualifications are thus gaining importance. As a consequence, investments in post-apprenticeship qualifications require proper economic evaluation, in particular if public financial and related support is involved. Moreover, individuals spend considerable resources in order to acquire higher level qualifications and these require some compensation. So far, conventional studies on the returns to education focus on the highest level of education and are less concerned with variations in the level of post-school qualifications over time and their economic impact.

This paper contributes to closing this gap in two ways. First, the role of sequential post-school qualifications in Germany is quantified. Then the wage effects of post-apprenticeship qualifications are evaluated. Post-apprenticeship qualifications are frequently acquired "on the job". Thus their return can be estimated with longitudinal data. Moreover, in order to account for time-constant unobserved individual heterogeneity, the fixed-effects estimator is used. This approach is very rare in the literature on the returns to formal qualifications.

The remainder of the paper is organized as follows. Section 2 provides descriptive evidence of the overall quantitative importance of sequences of post-school qualifications in Germany, in particular combinations of apprenticeship training and further education. Furthermore, some background information is given with respect to recent structural changes within the apprenticeship system and potentially related developments of post-apprenticeship education. The empirical literature is reviewed in section 3. The data set and methodological issues are described in section 4. Estimation results are presented in section 5. Section 6 concludes.

\footnotetext{
44 In the framework of the "Initiative for Qualification" [Qualifizierungsinitiative, translation A.G.] the Federal Government has acknowledged the vital importance of the concept of learning over the life cycle. Besides the measures focusing on post-school educational attainment, several other subsystems of the educational system have been targeted; see e.g. Bundesministerium für Bildung und Forschung (2008).
} 


\section{THE ROLE OF SEQUENTIAL POST-SCHOOL QUALIFICATIONS IN GERMANY}

\section{Descriptive evidence from the Qualification and Career Survey 2005/2006}

Kuckulenz (2007, p. 10) distinguishes three components of human capital: early ability (acquired in early childhood or innate), qualifications and knowledge acquired through formal education and skills acquired during working life through on-the-job training. Implicit in the distinction between formal education and on-the-job or continuous training is the notion that individuals acquire their formal qualifications before they start working, while continuous training refers to the period after individuals have entered the labor market. For a majority of the German population this dichotomy may apply. However, a non-negligible portion pursue combinations of initial vocational education plus further vocational education and/or plus academic education. Frequently, higher level post-school qualifications are acquired “on the job”, i.e. while working. In principle, various paths and sequences of post-school qualifications are possible. German Official Statistics, which typically provide figures on individuals' highest level of education attained, at the most implicitly reflect individuals' complete post-school educational paths.

The Qualification and Career Survey $(\mathrm{QaC})$ contains retrospective information on individuals' complete educational biographies and is thus very suitable for a descriptive analysis of the current role of sequential post-school qualifications in Germany. The $\mathrm{QaC}$ is a repeated cross-sectional survey of gainfully employed persons in Germany. Here data from the fifth and most recent wave (2005/2006) are used to analyze the importance of sequences of post-school qualifications. ${ }^{45}$ The distribution of persons with respect to their highest post-school qualification in the sample (of gainfully employed persons) is similar to the distribution in the whole population. ${ }^{46}$ In the QaCsample 69 per cent of the respondents completed initial vocational education, 7 per cent acquired a further vocational education certificate, while 24 per cent obtained an academic certificate.

The sample distribution of the total number of post-school qualifications individuals have obtained sheds light on the role of sequences of post-school qualifications in Germany. In 2005/2006 10.8 per cent of the respondents had no post-school qualification, while 89.2 per cent reported to have acquired at least one post-school qualification. The overall share of gainfully employed persons with more than one post-school qualification is a remarkable 25 per cent, suggesting that sequences of post-school qualifications are indeed important. The number of certificates obtained among those with some post-school education is distributed as follows: more than two thirds acquired one post-school qualification (71.8 per cent), 23.7 per cent of the respondents report to have obtained two post-school qualifications, 4.1 per cent said to have

\footnotetext{
${ }^{45}$ See section A.1 in the appendix for a more detailed description of the $\mathrm{QaC}$ and the sample.

${ }^{46}$ See introduction.
} 
acquired three post-school qualifications, while 0.5 per cent reported even four or five vocational qualifications.

FIGURE 1 provides an overview of the types and relative importance of sequences of postschool qualifications up to the third post-school qualification reported. Unsurprisingly, among those who have acquired at least one post-school qualification the large majority took the vocational route and completed initial vocational training (83.8 per cent). The distribution of certificates within the system of initial vocational education reflects the strong dominance of the dual system of apprenticeship training: 86.9 per cent completed apprenticeship training, while the rest completed full-time vocational schooling (12.1 per cent) or civil service training (1.1 per cent).

Among those with a first post-school qualification 28.2 per cent report to have acquired a second post-school qualification or more. The acquisition of a second post-school qualification is almost double as frequent after initial vocational education (30.3 per cent) than after academic education (17.2 per cent). Interestingly, combinations of initial vocational education and academic training are slightly more frequent (8.5 per cent) than sequences of basic vocational and further vocational education ( 7.7 per cent).

Though the significance of multiple post-school qualifications declines in the number of postschool qualifications, their share is not marginal: 16.1 (4.5) per cent of the persons with two (one) post-school qualifications obtained a third post-school qualification. Again, combinations of three post-school qualifications are more frequent among those who first completed initial vocational education than among the academically trained. However, combinations of initial vocational and further vocational education plus academic education, which would reflect a true break in the dichotomy between traditional vocational and academic routes and a facilitated access to tertiary education for non-Abitur holders, are very marginal: 0.25 per cent in the total of persons who first completed initial training and 3.3 per cent of those who combined initial and further vocational education (not shown in FIGURE 1).

In summary, sequences of post-school qualifications are important though evidently expandable in Germany. Most frequent are combinations of apprenticeship training and a second post-school qualification, yet to a considerable extent the second qualification is equivalent to the first which points to some further potential for improvement in terms of post-initial higher level achievement. Nonetheless, in more than half of the cases the second certificate corresponds to a higher level of education relative to the first. The acquisition of an academic degree following apprenticeship training is slightly more important than obtaining a further vocational education certificate (Master craftsperson or equivalent). 
FIGURE 1 EDUCATIONAL PATHS OF GAINFULLY EMPLOYED PERSONS

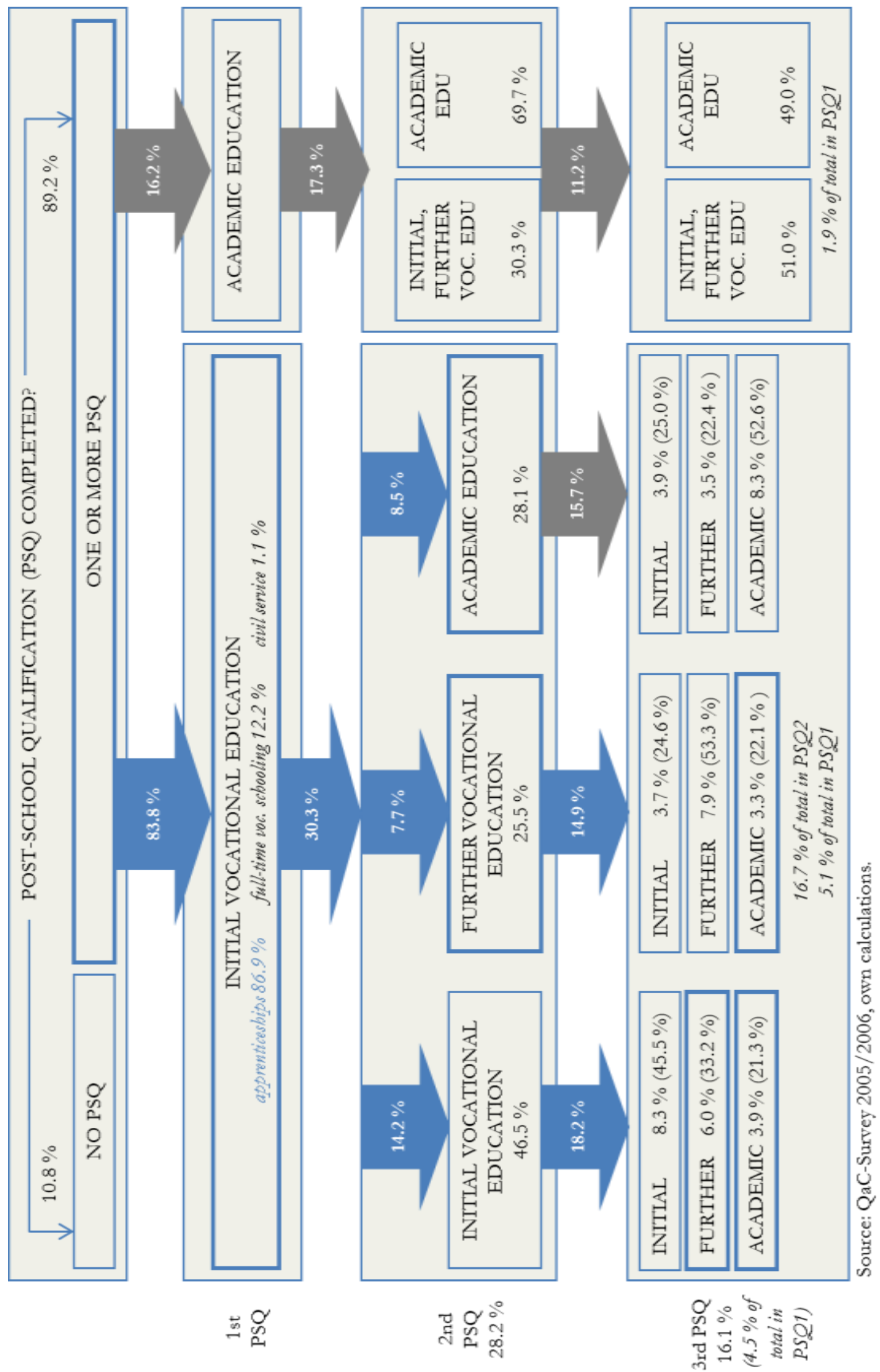


Focusing on the evaluation of the returns to post-apprenticeship further vocational or/and academic education, it is interesting to look both at the premium to acquiring either type of further education relative to not acquiring it and at the relative difference in the size of both premiums. The fact that academic education represents a higher level of formal education than further vocational education may provide some indication in these respects. It must be noted though that the two types of further education usually are not substitutes, but reflect relatively distinct and dichotomous educational paths individuals have followed. Generally, these are not independent of individuals' schooling. Also, there are strong interrelations with the type (occupation) of the prior apprenticeship and the underlying structures and traditions as established in the associated training sectors. The estimated premiums should be interpreted in the context of such qualitative differences, overall structural developments in the economy and related adjustments in the training sectors.

\section{Background and occupation/sector specific developments}

The literature on the economics of apprenticeship training distinguishes "craft" and "industry" apprenticeships. ${ }^{47}$ Industry apprenticeships are associated with training in medium-sized and large companies in the industrial, commercial and banking sectors, where net training costs are comparatively high, as are firm participation rates and post-apprenticeship retention, whereas craft apprenticeships refer to training in rather small companies in which the training can be operated at a small or even no cost and where retention rates are comparatively low (Franz \& Soskice, 1995; Soskice, 1994). Moreover, industry apprenticeships are ranked high among youth (Soskice, 1994), because their skill content is typically higher relative to craft apprenticeships (Steedman, 1993) and they represent the entry port to internal labor markets operated in large firms (Franz \& Soskice, 1995). In contrast, craft apprenticeships are often considered a secondbest alternative (Haverkamp et al., 2009).

Though particularly useful in providing a first impression of the persistent qualitative differences between apprenticeships, this division is misleading when it comes to analyzing the immense structural changes the dual system has undergone during the last decades. The rising importance of both information and other technology, the shift both from industry to services and in preferences of youth away from blue collar to white collar jobs have adversely affected both traditional industry and craft apprenticeships, while commercial and IT-related occupations have become increasingly attractive.

\footnotetext{
${ }^{47}$ This literature analyzes the determinants of the training participation of firms in the presence of both (substantial) net training costs and the provision of transferable skills (e.g. Niederalt, 2004; Harhoff \& Kane, 1997; Franz \& Soskice, 1995; Soskice, 1994; Steedman, 1993).
} 
In fact, there has been a strong negative trend in the total number of new contracts in the dual system starting in the late 1970's (Baethge et al., 2007). ${ }^{48}$ In terms of the training sectors which provide apprenticeships this decrease was most pronounced in the craft sector (currently the second largest provider), but also noticeable in industry \& commerce (currently the largest provider). The 2005 levels in new contracts in the two sectors have dropped to 62 and 88 per cent of the 1977 levels, respectively (Baethge et al., 2007, p. 26). The quantitatively important craft occupations most negatively affected were motor vehicle mechanics, hairdressers, electricians and food trade occupations, while in industry \& commerce the decreases were most pronounced in the industry mechanic, energy electronic technician and tool mechanic occupations (Baethge et al., 2007, pp. 30). In contrast, apprenticeships in commercial and servicerelated occupations such as management assistant for retail services, insurance and financial services broker, hotel and catering and, since the 1990's, IT occupations have seen a constant rise (Baethge et al., 2007, p. 31)..$^{49}$ These are also provided in the training sector industry \& commerce.

Therefore, a distinction between more traditional and modern apprenticeships better reflects these developments and the rather dissimilar patterns of both initial and further training options: purely vocational paths on the one hand, and mixed vocational and academic paths on the other hand. Recent developments in the craft and banking sectors ${ }^{50}$ are particularly illustrative in these respects and thus serve as anecdotal evidence.

The strong decline in new contracts in the craft sector puts into perspective its remaining quantitative weight in the training of apprentices relative to other sectors. While the craft sector's share in the total number of apprentices was 29 per cent in 2009, its share in new apprenticeships was slightly lower (27.7 per cent). ${ }^{51}$ Nonetheless, the relative training contribution of the craft sector is still high given its current share in total employment (11.7 per cent). ${ }^{52}$ In fact, Steedman (1993, p. 1285) is convinced that " $[\mathrm{w}]$ ithout the concessions made to ensure the survival of the Handwerk sector, Germany would not be able to provide a comprehensive youth training system". 53

\footnotetext{
48 The authors provide a recent comprehensive and critical survey of the persistent general decline in the absorptive capacity of the system of initial vocational education, in particular the dual system of apprenticeship training, since the 1970's, the declining importance of traditional industrial and craft apprenticeships which led to a decrease in training opportunities for lower level school leavers, and, at the same time, to a surge in measures in the transitory system which do not lead to a recognized vocational certificate.

49 The developments refer to West Germany.

50 The evidence refers to bank clerk apprenticeships only.

${ }^{51}$ Statistisches Bundesamt (2010).

52 www.zdh.de (retrieved 03/31/2011).

${ }_{53}$ It is only logical that retention rates are comparatively low. Yet, the consequences of such disparity between training and employment are by no means considered just positive (e.g. Neubäumer (1991) analyzes the consequences of training in excess of demand in Germany; v. Henninges (1994) studies the sectoral, occupational and status-related redistribution of workers (Facharbeiter) after apprenticeship training; Haverkamp et al. (2009)
} 
In contrast, even though the training occupation bank clerk was the $12^{\text {th }}$ most frequent apprenticeship and counted 13,276 new contracts in $2009^{54}$, its share in the total number of new contracts (apprentices) was 2.4 (2.3) per cent. ${ }^{55}$ In comparison, the banking industry's share in total employment was about 1.6 per cent in $2009 .{ }^{56}$ Despite their overall quantitatively modest role, ${ }^{57}$ bank apprenticeships are considered "the pinnacle of the dual system" (Finegold \& Wagner, 2002, p. 668). By creating an integrated system of initial training and further education options as well as the introduction of support programs for those who additionally opt for university, the banking sector has managed to meet the challenges not only from computerization, related changes in work organization, the introduction of new products and increased international competition, but also from a changing structure of new apprentices and correspondingly rising career aspirations (Finegold \& Wagner, 2002).

As a consequence, the share of Abitur holders in the total number of bank apprentices increased from 33 per cent in 1980 to 68 per cent in 1999 and has remained there since. ${ }^{58}$ In the craft sector only 6.2 per cent of the new apprenticeships in 2010 could be filled by school leavers who passed the Abitur (1996: 5.1 per cent ${ }^{59}$ ), which is clearly below the aggregate share of 20 per cent and marginal in comparison to the banking industry. ${ }^{60}$ Currently, there is a discussion in parts of the craft organizations about whether a higher share of Abitur holders in craft apprenticeships ${ }^{61}$ is necessary, about how to attract this group and, more importantly, about how to retain them in the sector (Haverkamp et al., 2009). Since the sector is also affected by technological change and computerization (Haverkampt et al., 2009; Pfeiffer, 1997), and has difficulties in overcoming its persistent structural crisis (Lagemann et al., 2004), this discussion seems indispensable.

The dissimilar structure of apprenticeships and their evolution in the craft and banking sectors is also reflected in the sectors' further education options. Though the Master craftsperson qualification is the traditional, well established and dominant form of further vocational

among other things specifically analyze the sectoral migration of craft-trained persons and the potential consequences for the craft sector).

54 The most frequent occupation among all new apprenticeships in 2009 with an intake of 33,205 was the management assistant for retail services (5.9 per cent in total of new contracts). As a comparison, of the $103 \mathrm{craft}-$ related training occupations (specializations not included) (www.zdh.de, retrieved 04/15/2011), motor vehicle mechatronic technicians ranked fourth in the list of the most frequent new apprenticeships, with an intake of 18,140 individuals (of which 93.4 per cent are trained in the craft sector) (Statistisches Bundesamt, 2010).

55 The banking sector belongs to the training sector industry \& commerce, whose total share in the 2009 intake was 59.2 per cent (Statistisches Bundesamt, 2010).

${ }^{56}$ www.statista.com (retrieved 04/18/2011) and www.destatis.de (retrieved 04/18/2011).

${ }_{57}$ Even bank apprenticeships have decreased non-negligibly after having reached a peak in 1991 (Baethge et al., 2007, p. 31), but are on a rise again since 2005 (Bundesinstitut für Berufsbildung, 2009, p. 322).

5868.4 per cent in 2010 (Statistisches Bundesamt, 2010).

${ }^{59}$ Haverkampt et al. (2009).

${ }^{60}$ Statistisches Bundesamt (2010).

${ }^{61}$ In training occupations such as optician or hearing aid audiologist higher level school leavers are already important. 
education in the craft sector ${ }^{62}$, the number of examinations passed has sharply declined from 36,842 to 22,000 during the period 1998 to 2005 (-40.3 per cent) (Müller, 2006). This negative trend has set in long before the amendment of the Trade and Crafts Code $^{63}$ in 2004, in which the number of trades liable to registration has been reduced from 94 to 41. In principle, the Master craftsperson certificate remains the sole admission requirement for setting up a business in the 41 trades liable to registration. ${ }^{64}$ However, access to the sector has been facilitated for technicians, engineers and other university graduates (Müller, 2006). Haverkamp et al. (2009) find that 12 per cent of the persons employed in the craft sector in 2006 obtained a Master certificate, while 5.6 per cent held an academic degree. ${ }^{65}$

In contrast, in the banking sector the share of positions demanding high skills (further education or graduate level) had grown to 50 per cent by 1999 already (19 per cent in 1975) (Finegold \& Wagner, 2002). A variety of further training options exist for apprentices who do not attend university. Among them are special firm-specific trainee programs, programs at the sector-run Bank Academy or co-operations with state-run higher-education institutions (Finegold \& Wagner, 2002, pp. 679). Similar co-operations exist in the craft sector, but so far they do not seem to have a pronounced impact. During the 1980's and 1990' the share of bank apprenticeship graduates who went on to university grew from about 15 to about 40 per cent (Finegold \& Wagner, 2002, p. 673) and banks responded to this development by investing in support programs in order to retain their top apprentices which indeed significantly increased their retention rates (pp. 680). Overall, Finegold \& Wagner (2002, p. 683) conclude that "bank apprenticeships may be a more relevant model than traditional German apprenticeships, since increasingly these modern apprenticeships are a stepping stone to some form of further or higher education, rather than an alternative to it."

In conclusion, the evolution of apprenticeships in the two sectors though not representative of the dual system and its heterogeneous structure is very illustrative in terms of the diverging impact of technological and structural change on the established educational systems. While bank apprenticeships represent modern high-skill, IT-intensive white collar jobs, many craft apprenticeships represent more traditional, lower- or medium-skill blue collar jobs which exist both in the craft and industry sectors. Since apprenticeship training and further education options are closely intertwined, it is only logical that changes or adjustments in the former had

\footnotetext{
${ }^{62}$ According to Müller (2006), an average of about two thirds of the annual total number of Master craftsperson examinations in Germany are taken in the craft sector.

${ }^{63}$ The Trade and Crafts Code is the legal foundation of the German craft sector. It comprises regulations concerning the business creation in craft-specific trades, apprenticeship and Master craftsperson examinations or the craftspecific organizations.

${ }_{64}$ The owner-manager-principle [Inhaberprinzip, translation A.G.], binding the educational requirement to the owner-manager, has been abolished.

${ }^{65}$ Figures are based on data from the Qualification and Career Survey 2005/2006.
} 
repercussions on the latter. It can be expected that this is also somehow reflected in the returns to both types of post-apprenticeship qualifications, i.e. further vocational and academic education.

\section{REVIEW OF THE LITERATURE}

"[T]he very difficult task of uncovering the causal effect of education in labor market outcomes" (Card, 2001, p. 1127) is at the heart of many contributions to the literature on the returns to education that have emerged since the seminal contributions of Becker (1964) and Mincer (1974). The early literature has been comprehensively surveyed in Card (2001, 1999) and Griliches (1977). More recent surveys were provided by Flossmann \& Pohlmeier (2006) and Blundell et al. (2005).

Against the background of this paper some observations are comparably noticeable throughout the literature. The large majority of contributions take a years-of-schooling approach which may be valid for the U.S., but does not reflect the track or streaming nature of educational systems such as the German (Flossmann \& Pohlmeier, 2006; Card, 1999). ${ }^{66}$ Also, most studies treat education as a time-invariant variable and estimate the return to the highest level of education achieved, thereby ignoring sequences of qualifications and differential paths individuals might have taken to reach a particular level of education. Dearden et al. (2002) are an exception in this respect and include all qualifications an individual has obtained in their cross-sectional analysis. Finally, cross-sectional studies are preponderant in the literature, as are instrumental variables methods to overcome the likely correlation between schooling and unobserved ability to recover unbiased estimates of the return to education.

In contrast, longitudinal analyses are relatively rare, even though panel data are particularly suitable if individual-specific effects need to be controlled for (e.g. Cornwell \& Rupert, 1988; Hausman \& Taylor, 1981). Nonetheless, even in the presence of panel data most authors treat education as a time-constant regressor. Sometimes any variation in individuals' schooling over time has been deliberately ignored (e.g. Skarupke, 2005) or could not be observed because of rather short periods of observation (e.g. Wagner \& Lorenz, 1989). Other studies do not discuss this issue and simply take the time-invariance of education as a given (e.g. Kalwij, 2000; Hausman \& Taylor, 1981). In the years-of-schooling context Angrist \& Newey (1991) deliver one of the few contributions explicitly accounting for individual changes in education over time.

If education is endogenous and correlated with individual-specific factors which are frequently not observed in available datasets (most notably ability), fixed-effects estimation recovers a

\footnotetext{
${ }^{66}$ See also the second contribution in this dissertation.
} 
consistent estimate of the return to education. In fact, the orthogonality assumption of no correlation of the regressors with the unobserved effect can be tested with panel data (Hausman, 1978) and is usually rejected in wage equation applications (Skarupke, 2005; Kalwij, 2000; Hausman \& Taylor, 1981). Unfortunately, fixed-effects estimation not only eliminates the individual-specific effect from the model, but also all time-invariant variables (Cornwell \& Rupert, 1988; Hausman \& Taylor, 1981). Thus, in such a framework the return to education cannot be identified if the education variable is time-constant.

Hausman \& Taylor (1981) therefore propose an IV approach which takes account of both the time-invariance and endogeneity of education. Their method does not rely on an excluded instrumental variable to estimate the return to schooling, but makes use of the time-varying regressors from the wage equation itself which are supposedly uncorrelated with the individualspecific effect (Hausman \& Taylor, 1981). Several US applications are based on the HausmanTaylor-estimator and mostly focus on the efficiency gains from variations in the instruments or corrections in the data set (see the discussions in Baltagi \& Khanti-Akom, 1990 and Cornwell \& Rupert, 1988). Skarupke (2005) uses the Hausman-Taylor approach to estimate the return to an additional year of education in Germany.

Kalwij (2000) provides an Estimated Generalized Instrumental Variable estimator of the return to schooling in the Netherlands. He also uses time-varying exogenous regressors as instruments, but additionally includes a fifth-order polynomial in age thereby taking account of the observed nonlinear relationship between schooling and age (Kalwij, 2000, p. 66).

In contrast, Angrist \& Newey (1991) observe increases in schooling over time for about 20 per cent of the persons in their sample and are thus able to estimate the return to formal schooling using fixed effects.

With respect to the direction of the ability bias, all panel studies mentioned find that their return to schooling estimates (substantially) rise relative to conventional OLS or GLS estimates in the regressions accounting for the endogeneity of education. Wagner \& Lorenz (1989) are the exception. However, they are also the only contribution to find no correlation between the regressors and the individual-specific effects and therefore preferred random to fixed effects estimation. Their random effects and OLS return-to-schooling estimates are equal in size. The finding of a negative ability bias is in line with the discussion in Griliches (1977, p. 18) who concludes that "[i]n optimizing models there is no good a priori reason to expect the "ability bias" (...) to be positive". In his model ability exclusively "affects the amount of initial human capital" (Griliches, 1977, p. 15). "[S]chooling and ability are substitutes instead of complements" in such a setting (Angrist \& Newey, 1991, p. 323). 
Büchel \& Pannenberg (2004) and Pischke (2001) provide estimates of the returns to continuous (on-the-job) training in Germany, not formal education, using longitudinal data. Similar to Angrist \& Newey (1991), in both papers fixed-effects methods are used to account for individualspecific effects. In addition, the authors estimate a random trend model to account for the potential correlation between training participation and wage growth. ${ }^{67}$ Büchel \& Pannenberg (2004) who analyze the training returns in the framework of the model of potential outcomes use this extension following a specification test ${ }^{68}$ based on Heckman \& Hotz (1989) which indicates that the fixed-effects specification does not sufficiently account for the selection into training. The causal model of potential outcomes as introduced by Rubin (1974) has become the basic framework for the analysis of causal effects of treatments in the program evaluation literature (Imbens \& Wooldridge, 2009; Heckman et al., 1999). Increasingly, this approach also finds its way into the literature on the returns to (formal) education (Flossmann \& Pohlmeier, 2006; Blundell et al., 2005; Card, 2001). However, longitudinal analyses which have a long tradition in the literature on program evaluation remain an exception in the literature on the returns to education.

\section{METHODOLOGY}

\section{Data set, sampling and weighting issues}

We use data from the most recent version of the German Socio-economic Panel (SOEP v26). The SOEP is a longitudinal survey of households and persons living in Germany. ${ }^{69}$ The data are provided by the German Institute for Economic Research (DIW) and are available since 1984 (New Länder since 1990). There is a variety of questionnaires covering a very wide range of topics relating not only to the current situation of individuals and households, but also to retrospective (biography-related) information on education, childhood, family etc. In addition to the usual cross-sectional distribution of the data the 2010 version for the first time contained the data in long format from which the longitudinal sample is constructed. In contrast to most studies on the returns to education and given the subject of the paper, explicit use is made of both the longitudinal nature of the data and changes in the level of qualification over time to adequately control for individual-specific effects.

\footnotetext{
${ }^{67}$ To remove the individual-specific level and growth effects, the model must be transformed twice. Usually, the data will be first-differenced, before the wage equation is estimated with fixed effects (e.g. Wooldridge, 2010).

68 This test is based on the inclusion of pre-treatment (pre-training) indicators to control for potential systematic differences between those receiving training and those who do not. Büchel \& Pannenberg (2004, p. 87) include a dummy variable which takes the value one in the period prior to future participants' (first) training period.

69 The Desktop Companion to the German Socio-economic Panel (2005) is a comprehensive and helpful introduction to the dataset. For item correspondence lists, word and variable search check the online tool soepinfo.
} 
The sample includes all employed persons aged 18 to 65 whose first or highest level of postschool qualification is initial vocational education. Persons are selected if they obtained their school and post-school qualifications in Germany and if they worked full- or part-time during the period of observation. The analysis is not restricted to full-time working individuals since sometimes individuals may well acquire a second qualification while working part-time. ${ }^{70}$

For the estimations three subsamples were constructed. The base sample includes persons in dependent employment only (including those working in civil service) (“dependent"), while the second sample ("all") includes both persons in dependent employment and the self-employed. A third sample is restricted to persons in self-employment ("self").

The sample choice is not restricted to any specific subsample of the SOEP and includes persons from subsamples A to $\mathrm{H}^{71}$ In the base sample "dependent" the large majority of the observations are from samples A (German West: 48.5 per cent), C (German East: 21.3 per cent) and F (Innovation, 2000: 17.8 per cent). The rest of the observations are from samples B (Foreigner West: 5.0 per cent), E (Refreshment, 1998: 3.3 per cent), G (High Income, 2002: 1.7 per cent), H (Refreshment, 2006: 1.3 per cent) and D (Immigrant, 1984-1993: 1.1 per cent). The distribution in the sample "all" is almost identical, while the sample "self" contains a slightly higher (lower) proportion of persons from subsamples $G(C)$. Overall, the base sample is an unbalanced panel with a total of 73,765 person-year observations from 9,939 individuals and observations from 1984 to 2009 (East Germany 1991 to 2009). In order to apply fixed effects methods, the minimum number of observations per person has to be two.

The SOEP like any panel study is subject to oversampling and attrition. In order to control for it, the SOEP provides corresponding weighting tools along with the data. Usually it is recommended to use the cross-sectional weights for cross-sectional analyses, while longitudinal analyses require longitudinal weighting which combines the cross-sectional or structural weights and the so-called staying factors (the inverse of individuals' staying probability). According to the SOEP's Desktop Companion (2005, p. 40), “(...) the weighting factor for a longitudinal sample can be calculated as the product of the weighting factor of the start wave and all the "reciprocal staying factors" to the end of the longitudinal sample." In practice however, weighting issues are handled very differently. Skarupke (2005) uses 11 waves of SOEP data (1988-1998) to analyze the returns to years of schooling. He does not report any weighting procedure, while Pischke (2001) uses the cross-sectional weights of the last wave of observation in his longitudinal analysis of the returns to continuous training using four waves of SOEP data (1986-1989). Büchel \&

\footnotetext{
${ }^{70}$ In some occupations (e.g. hairdresser) it is not uncommon that individuals enter a further vocational education program (Master craftsperson qualification) even though they work in a full-time job.

${ }^{71}$ There is no observation from the 2009 Incentivation sample as at least two observations per person are required to apply fixed effects.
} 
Pannenberg (2004) who use a longitudinal sample from the SOEP 1984 to 2001 construct the longitudinal weights based on the staying factors for the waves which enter their estimation sample. Another recommendation involves the additional use of sample design-based drop outs to construct the longitudinal weights. ${ }^{72}$ What does this mean? Assume an individual's first and last period of observation is determined conditional on complete sets of information as required for this analysis. Assume further that in between there are two additional waves with complete sets of information, but in one wave the individual is not employed. Usually, this wave would be dropped from the start, i.e. it would not enter the estimation sample. However, if the staying factor of this wave is available, it is recommended to first calculate the longitudinal weight including this year's staying factor before the entire year's information is dropped from the analysis. Therefore, this approach makes a difference between unit non-response and sample design-based drop outs, because in case of the former no staying factor is available, whereas in the latter case there potentially is. ${ }^{73}$

\section{The empirical model and variable construction}

The longitudinal version of the usual augmented Mincer-type wage equation to be estimated can be written as

$\ln w_{i t}=P S Q_{i t} \beta+X_{i t} \gamma+\varepsilon_{i t}$,

with the subscripts referring to individual $i=1, \ldots, N$ in period $t=1, \ldots, T$. The dependent variable is the natural logarithm of individuals' real gross hourly wage $\operatorname{rate}^{74}, P S Q_{i t}^{\prime}$ is a vector of dummies indicating whether an individual acquired a higher level qualification subsequent to initial vocational education during the period of observation, $X_{i t}$ is a vector of additional covariates and $\varepsilon_{i t}$ is the idiosyncratic error. Some variables, in particular the education dummies, require some more detailed consideration.

For the analysis of qualifications the SOEP-provided generated education variables are used. Persons are selected if their first (observed) post-school qualification is an initial vocational qualification, i.e. apprenticeship training or full-time vocational schooling. Individuals who completed civil service training are not included, because the SOEP does not distinguish the four

\footnotetext{
${ }^{72}$ This procedure was recommended by Martin Kroh. He is in charge of survey sampling, non-response analysis and weighting at the SOEP group. Mr. Kroh does not bear any responsibility with respect to the actual calculation of the longitudinal weights. Any related errors are my own.

${ }^{73}$ Apparently, this difference was not made in Büchel \& Pannenberg (2004).

${ }^{74}$ The variable is constructed by means of the generated variables for the current monthly gross labor income (pglabgro), deflated, and the actual hours worked per week (pgtatzt). To calculate the hourly wage, measures of 4.348 weeks per month and 365.25 days per year are assumed (leap years considered) (Skarupke, 2005, p. 54). The annual information on work hours and labor earnings from the Cross-National-Equivalent-File was considered as well. However, the annual work hours refer to the previous year. Moreover, the annual labor earnings variable is said to be a very crude measure only and less consistent in terms of individual's current employment status, occupational position and working time.
} 
different levels of training of which only basic and middle level training are equivalent to initial vocational education. Two dummy variables are then constructed to indicate whether or not a person acquired a second post-school qualification during the period of observation. The dummy variable voc2 refers to the further vocational education level which includes Master craftspersons, technicians or graduates from health care schools, whereas the dummy variable uni includes persons who, in addition to their initial vocational education certificate, acquired an academic degree from a university of applied sciences (Fachhochschule) or a university. The dummy turns one upon completion of the second post-school qualification and remains one thereafter. As such the estimates measure the average permanent effect of the second post-school qualification on wages (cp. Büchel \& Pannenberg, 2004). Sequences of further vocational and academic education are considered in terms of their combined effect (voc2uni).

In section 2 it could be observed that even sequences of equivalent types of post-school qualifications are not uncommon. Therefore, it was also considered to include regressors which indicate the total number of certificates acquired for each type of post-school qualification (initial vocational education, further vocational education and academic training). Unfortunately, the generated education variables do not reflect complete educational biographies. In particular, multiple certificates from the same type of qualification (e.g. apprenticeship training) are not reported, as are multiple certificates from different though equivalent types of qualification which are summarized in one category (e.g. Master craftsperson certificate plus technician certificate). In addition, there seem to be inconsistencies between the generated education variables and the annual information about recent changes in qualifications (i.e. completed educational programs). For this reason and further assuming that the wage effects of multiple equivalent certificates are rather small, their impact on wages is not analyzed. Also, the specific focus of the paper is on combinations of initial vocational education and higher level post-school qualifications, and the wage effects arising from this higher level qualification. These changes in individuals' level of post-school qualification are sufficiently accounted for in the data.

Besides the qualification dummies which indicate a change in the level of education over time, other covariates which supposedly affect wages are included in the wage equation. The more conventional covariates which are commonly used in cross-sectional analyses of the returns to education are work experience, work experience squared, a set of dummies indicating the size of the firm an individual works for as well as a set of dummies which indicate the economic sector this firm operates in. Total work experience is usually calculated as an individuals' age minus his or her years of education (derived from the highest level of qualification achieved) minus six (children on average start school at the age of six). This measure is rather crude and does not account for the fact that individuals may be in education and work in a regular job at the same 
time. Instead, the measure used here is derived from monthly calendar information on employment status and is the sum of individuals' total labor market experience in full-time and part-time employment. ${ }^{75}$ This measure is assumed to be more precise than the conventional measure and thus less prone to measurement error.

Furthermore, in the sample "all" which includes persons both in dependent and self-employment the self-employed should be accounted for separately since their wage determinants might differ from those in dependent employment. First, the dummy variable self is set to one in those periods in which an individual is self-employed. Secondly, the wage premia associated with voc2 and uni, i.e. the acquisition of a higher level post-school education certificate subsequent to initial vocation education, might differ if a person sets up their own business. This specific interest rests upon the fact that further vocational education remains an important requirement for setting up a business in over 40 occupations in the craft sector. In addition, further vocational education is specifically oriented toward the potential future business creation of their students, whereas academic education is not. This might be reflected in the combined effects of the two types of post-school qualification and self-employment, respectively. On the other hand, entrepreneurial success may not necessarily be related to the level of qualification.

Büchel \& Pannenberg (2004), Pischke (2001) and Wagner \& Lorenz (1989) who all use the SOEP data in their analyses have included other controls which may be particularly important in longitudinal settings: individuals' tenure, i.e. the number of years individuals are working with their current employer and the total number of employer changes. ${ }^{76}$ The number of employer changes is constructed from the variable tenure. ${ }^{77}$ In addition, status and occupational mobility may also be important determinants of movements in wages over time. Büchel \& Pannenberg (2004) analyze the impact of continuous training on the probability of a career jump (status mobility). Their job promotion variable does not enter their wage equation estimations though. Büchel \& Pannenberg (2004) define career advancement as an individual's upward movement in the occupational position. ${ }^{78}$ Their analysis is restricted to persons in dependent employment, where persons may switch positions both within the main categories worker, employee and civil servant as well as between these categories (Büchel \& Pannenberg, 2004, p. 89). Determination of advancement within categories is straightforward, while switches between categories are less

\footnotetext{
75 Person-generated variables pgexpft (total labor market experience, full-time) and pgexppt (total labor market experience, part-time). The variables are measured in years with decimalized months.

${ }^{76}$ Pischke (2001, p. 538) used "a dummy for years in which the worker switched jobs". Unfortunately, it is not clear whether job change refers to employer change or rather occupational change.

77 Variable pgerw 2 t (person-related generated and status variables file), measured in years with decimalized months.

${ }^{78}$ Variable $p g s t i b$ (person-related generated and status variables file).
} 
easily ranked and may involve some arbitrariness. ${ }^{79}$ The categorization used here is based on the associated level of qualification and the (assumed) degree of managerial responsibility. ${ }^{80}$ Accordingly, a dummy indicates whenever an upward movement is detected relative to the previous period of observation. The variables tenure, number of employer changes and job promotion only enter the estimations based on the sample "dependent".

Similarly, occupational mobility, i.e. a change in occupation is defined as any change in the coding of the occupational classification. ${ }^{81}$ This variable enters all estimations. Finally, fluctuations in the macro economy are accounted for by a set of year dummies. ${ }^{82}$

There remain structural differences between East and West Germany which may also be reflected in the returns to education. Therefore, separate estimations are run for East and West Germany. The corresponding variable used refers to the sampling region ("old/new Länder") and not the workplace location which would have been a better choice. Unfortunately, the variable workplace location is available only from 1995 onwards. Any biases which may arise from East-West (and vice versa) commuting are assumed to be negligible.

\section{Estimation related issues}

If educational achievement is endogenous and thus related to ability, motivation, energy etc., and if the latter are either unobservable to the researcher or only crudely measured, any analysis of the returns to education requires adequate control of the potential correlation between education and unobserved heterogeneity in order to produce unbiased estimates of these returns.

Longitudinal data are particularly suitable for tackling this fundamental problem and the underlying basic panel data model used here is the linear unobserved effects panel data model which can be written as follows (Wooldridge, 2010: pp. 285):

$y_{i t}=x_{i t} \beta+c_{i}+u_{i t}, \quad t=1, \ldots, T$.

The $x_{i t}$ are the regressors and the $\beta$ are the corresponding coefficients to be consistently estimated, $c_{i}$ is an individual specific unobserved effect which is time constant and $u_{i t}$ is the idiosyncratic error which is assumed to be uncorrelated with the covariates and the unobserved

\footnotetext{
79 Büchel \& Pannenberg (2004) do not provide an exact definition of when a movement between categories is regarded as an individual's advancement in his or her occupational position.

${ }^{80}$ Group 1 (ranked lowest) to group 6 (ranked highest) according to occupational position: (1) untrained worker, semi-trained worker, agricultural worker, employee with simple tasks (untrained); (2) trained worker, trained worker in agriculture, trained employee with simple tasks, low-level civil service; (3) assistant forman/team leader (Vorarbeiter/Kolonnenführer), middle-level civil service; (4) foreman (Meister/Polier/Industrie- und Werkmeister), forman in agriculture (Brigadier/Meister in der Landwirtschaft), qualified professional; (5) managerial in agriculture, highly qualified professional (managerial function), high-level civil service; (6) executive function, executive-level civil service.

${ }^{81}$ Variable pgklas (person-related generated and status variables file; Klassifikation der Berufe des Statistischen Bundesamtes von 1992). Note that the measure constructed here is rather crude, since it involves a switch within Berufsgruppen, i.e. from e.g. salesperson (not specified) to salesperson textiles and leather.

${ }^{82}$ For reasons of space these are not summarized in the appendix.
} 
effect. Depending on whether the individual specific effect is correlated with the regressors or not, the model should be specified as a fixed or random effects model, respectively and should be estimated accordingly.

Hausman (1978) developed a specification test which can also be applied in the context of comparing fixed and random effects estimators. The test uses the fact that the fixed effects estimator is consistent if the individual specific effect is correlated with the regressors while the random effects estimator is not. Thus, if the estimators differ systematically, there is evidence against the null hypothesis of consistency of the random effects estimator. Alternatively, rejection of the null hypothesis suggests the presence of endogenous regressors and the use of the fixed effects estimator (e.g. Wooldridge, 2010, pp. 328; Baum, 2006, pp. 230). The Hausman test is implemented in Stata under the hausman command. Unfortunately, the command can neither be combined with the weights option to control for attrition nor the vce(robust) option to make the standard errors robust to heteroskedasticity and within-panel serial correlation.

A more generalized version of the test which can be combined with the vce(robust) option is the overidentification test xtoverid (Schaffer \& Stillman, 2010). ${ }^{83}$ This test of overidentifying restrictions can be applied in the fixed vs. random effects context, because the additional orthogonality conditions implied by random effects, i.e. the individual specific effect (in addition to the idiosyncratic error) is not correlated with the regressors, can be interpreted as overidentifying restrictions (see Schaffer \& Stillman, 2010). The test can be similarly interpreted as the Hausman test, i.e. its rejection casts doubt on the consistency of the random effects estimator.

The xtoverid routine was applied with each sample and specification and suggested that the regressors are in fact endogenous. ${ }^{84}$ Therefore, the wage equations were estimated with fixed effects. The fixed effects or within estimator to be well identified requires some variation in the data over time. ${ }^{85}$ Even though sequences of post-school qualifications are relatively frequent in Germany, the variation in the constructed SOEP samples is relatively low. This is not overly surprising since we need to observe persons with completed apprenticeship training who acquire a second post-school qualification during the period of observation and who work before and after the acquisition of their higher level certificate. In particular, only very few persons could be observed whose second post-school qualification was an academic degree and even fewer obtained both a further vocational plus an academic certificate during the period of observation.

\footnotetext{
${ }^{83}$ The command is not directly implemented in Stata and needs to be downloaded typing ssc install xtoverid.

${ }^{84}$ The test statistics are reported together with the estimation results in the next subsection.

${ }^{85}$ In the literature nothing is said about how much variation is actually required. Only Baum (2006, p. 223) states that "[T] the coefficients on variables with small within standard deviations are not well identified" and refers to an example where a within standard deviation of .0552 may cause concern. For a comparison see the summary statistics in the appendix.
} 
Also, the proportion of persons who acquired either type of second degree and became selfemployed during the period of observation is low. In contrast, the variation in the variable voc2 (persons with further vocational education) is comparatively higher. Therefore, the main effects may be better identified than the interactions effects which should be kept in mind when looking at the results.

\section{Some descriptive evidence}

Summary statistics of all variables in the three subsamples are provided in the appendix, as are mean age figures of individuals at the time of completing their second post-school qualification. TABLE 1 gives an impression of how far the distinction between more traditional vocational paths and modern mixed vocational and academic paths, as suggested in Section 2, is reflected in the data. The table summarizes the job classification $\operatorname{codes}^{86}$ of individuals' current job at the time they completed (reported) their second post-school qualification, by type (level) of the second qualification. The differences are apparent and well reflect the picture provided earlier.

Craft specific occupations are particularly important for individuals with further vocational education (codes 514, 712 to 744). Other important industry and technical occupations are industry foremen (1222) and physical and engineering science associate professionals (mostly technicians, 31). Together these occupations make up a share of about 40 per cent. If laborers, machine and plant operators as well as assemblers are added, the share of craft and industry specific occupations rises to almost 50 per cent.

In contrast, these occupations play only a minor role for individuals with mixed vocational and academic paths. Here, managing, commercial and service-related occupations dominate. Numerical clerks, mostly bank clerks, have a non-negligible share of 14.1 per cent (412). Interestingly, high-skill technical occupations, most notably architects, engineers and related professionals (214) make up almost one fifth of those with academic education. This finding does not contradict the earlier discussion, but indicates that high skill further education is important not only in commercial occupations, but also in technical occupations.

\footnotetext{
86 The SOEP provides the ISCO-88 codes, which refer to the 1988 International Standard Classification of Occupations of the International Labour Organization (ILO).
} 
TABLE 1 CLASSIFICATION OF CURRENT JOB BY TYPE OF SECOND POSTSCHOOL QUALIFICATION, SAMPLE „DEPENDENT“

\begin{tabular}{|c|c|c|c|}
\hline & & \multicolumn{2}{|c|}{ second post-school qualification } \\
\hline \multicolumn{2}{|c|}{ ISCO- 88 code and occupations } & $\begin{array}{l}\text { further vocational } \\
\text { education }\end{array}$ & academic education \\
\hline 01 & armed forces & 0.6 & \\
\hline 12 & administrative and commercial managers & 0.3 & 1.1 \\
\hline 121 & directors and chief executives & & 1.1 \\
\hline 1222 & production and operations department managers in manufacturing & 2.5 & 1.1 \\
\hline 1225 & $\begin{array}{l}\text { production and operations department managers in restaurants and } \\
\text { hotels }\end{array}$ & 0.3 & \\
\hline 1227 & production and operations department managers in business services & & 2.2 \\
\hline 123 & other department managers & 1.1 & 6.5 \\
\hline 13 & general managers & 0.8 & \\
\hline 212 & mathematicians, statisticians and related professionals & & 1.1 \\
\hline 213 & computing professionals & 0.8 & 3.3 \\
\hline 214 & architects, engineers and related professionals & 1.4 & 17.4 \\
\hline 22 & life science and health professionals & & 2.2 \\
\hline 23 & teaching professionals & 0.3 & 1.1 \\
\hline 24 & other professionals & 1.4 & 8.7 \\
\hline 31 & physical and engineering science associate professionals & 11.1 & 6.5 \\
\hline 32 & life science and health associate professionals & 9.7 & 2.2 \\
\hline 33 & teaching associate professionals & 2.8 & 1.1 \\
\hline 341 & finance and sales associate professionals & 3.1 & 6.5 \\
\hline 342 & business services agents and trade brokers & & 2.2 \\
\hline 343 & administrative associate professionals & 3.6 & 9.8 \\
\hline 344 & customs, tax and government related associate professionals & 1.1 & \\
\hline 345 & police inspectors and detectives & & 1.1 \\
\hline 346 & social work associate professionals & 2.2 & 1.1 \\
\hline 347 & artistic, entertainment and sports associate professionals & 0.3 & \\
\hline 411 & secretaries and keyboard operating clerks & 0.8 & \\
\hline 412 & numerical clerks & 3.9 & 14.1 \\
\hline 413 & material-recording and transport clerks & 1.9 & 4.3 \\
\hline 414 & library, mail and related clerks & 0.8 & \\
\hline 419 & other office clerks & 0.6 & 1.1 \\
\hline 42 & customer service clerks & 1.1 & \\
\hline 512 & housekeeping and restaurant service workers & 1.4 & \\
\hline 513 & personal care and related workers & 9.2 & \\
\hline 514 & other personal service workers (hairdressers and related) & 0.6 & \\
\hline 516 & protective services workers & 0.6 & \\
\hline 522 & shop salespersons and demonstrators & 0.6 & \\
\hline 61 & market-oriented skilled agricultural and fishery workers & 0.6 & \\
\hline 711 & miners, short-firers, stone cutters and carvers & 1.1 & \\
\hline 712 & building frames and related trades workers & 1.1 & \\
\hline 713 & building finishers and related trades workers & 7.0 & \\
\hline 714 & painters, building structure cleaners and related trades workers & 0.6 & \\
\hline 721 & $\begin{array}{l}\text { metal moulders, welders, sheet-metal workers, structural-metal } \\
\text { preparers, and related trades workers }\end{array}$ & 1.4 & \\
\hline 722 & blacksmiths, tool-makers, and related trades workers & 1.7 & \\
\hline 723 & machinery mechanics and fitters & 6.1 & 1.1 \\
\hline 724 & electrical and electronic equipment mechanics and fitters & 1.4 & 1.1 \\
\hline 731 & precision workers in metal and related materials & 1.7 & \\
\hline 734 & printing and related trades workers & 0.6 & \\
\hline 741 & food processing and related trades workers & 2.2 & \\
\hline 742 & wood treaters, cabinet makers and related trades workers & 2.2 & \\
\hline 744 & pelt, leather and shoemaking trades workers & 0.6 & \\
\hline 81 & stationary-plant and related operators & 2.2 & \\
\hline 82 & machine operators and assemblers & 1.1 & \\
\hline 83 & drivers and mobile-plant operators & 1.7 & 1.1 \\
\hline 91 & sales and services elementary occupations & 0.3 & \\
\hline 93 & labourers in mining, construction, manufacturing and transport & 1.7 & \\
\hline n.a. & & & 1.1 \\
\hline & Total & 100 & 100 \\
\hline
\end{tabular}

Source: Socio-economic Panel (SOEP) (2010). 


\section{ESTIMATION RESULTS}

Here the estimation results are presented for the education related variables. The results for the other covariates are summarized in the appendix. If feasible, separate estimations were made for West and East Germany, males and females. Recall that data on persons living in West Germany are available for the period 1984 to 2009, while persons living in East Germany entered the SOEP in 1991. The two sets of year dummies were adjusted accordingly. ${ }^{87}$

TABLE 2 provides the fixed effects estimates for completing further vocational education, academic education or both. The results refer to persons in dependent employment. Having accounted for time constant unobserved heterogeneity the estimates allow a causal interpretation. It can be seen that investing in further vocational education (voc2) has been financially beneficial only for males in West Germany. The coefficient corresponds to a wage premium of 5.7 per $\operatorname{cent}^{88}$ which is relatively modest. Though the point estimates in the other specifications are also positive, there is no statistically significant return to post-apprenticeship investments in further vocational education for West-German females and both males and females living in East Germany.

TABLE 2 FIXED EFFECTS ESTIMATES OF SECOND POST-SCHOOL QUALIFICATION - SAMPLE "DEPENDENT"

\begin{tabular}{|c|c|c|c|c|c|c|}
\hline \multirow[b]{2}{*}{ Variables } & \multicolumn{3}{|c|}{ West } & \multicolumn{3}{|c|}{ East } \\
\hline & aggregate & males & females & aggregate & males & females \\
\hline \multicolumn{7}{|l|}{ 2nd post-school qualification } \\
\hline further vocational (voc2) & $\begin{array}{l}.0667 * \\
(.0377)\end{array}$ & $\begin{array}{l}.0554^{*} \\
(.0302)\end{array}$ & $\begin{array}{l}.0924 \\
(.0855)\end{array}$ & $\begin{array}{l}.0513 \\
(.0348)\end{array}$ & $\begin{array}{l}.0337 \\
(.0496)\end{array}$ & $\begin{array}{l}.0517 \\
(.0434)\end{array}$ \\
\hline academic (uni) & $\begin{array}{l}.1955^{* * *} \\
(.0537)\end{array}$ & $\begin{array}{l}.2004 * * * \\
(.0606)\end{array}$ & $\begin{array}{l}.1588^{* *} \\
(.0791)\end{array}$ & $\begin{array}{l}.3604^{* * *} \\
(.1143)\end{array}$ & $\begin{array}{l}.3250^{* *} \\
(.1292)\end{array}$ & $\begin{array}{l}.3736 * * \\
(.1464)\end{array}$ \\
\hline $\operatorname{voc} 2 *$ uni & $\begin{array}{l}-.4110^{* * *} \\
(.1551)\end{array}$ & $\begin{array}{l}-.1112 \\
(.0837)\end{array}$ & $\begin{array}{l}-.4906^{* * *} \\
(.1468)\end{array}$ & $\begin{array}{l}-.5865^{* * *} \\
(.1226)\end{array}$ & no obs & $\begin{array}{l}-.6384 * * * \\
(.1547)\end{array}$ \\
\hline \multicolumn{7}{|l|}{$\overline{\text { Observations } / \mathrm{R}^{2}}$} \\
\hline $\mathrm{N}$ & 55,746 & 31,470 & 24,276 & 18,019 & 10,011 & 8,008 \\
\hline within $\mathrm{R}^{2}$ & 0.141 & 0.160 & 0.133 & 0.116 & 0.121 & 0.134 \\
\hline \multicolumn{7}{|l|}{ Specification test: xtoverid } \\
\hline Sargan-Hansen statistic & 628.731 & 320.994 & 253.991 & 378.547 & 243.749 & 234.803 \\
\hline $\mathrm{p}$-value & 0.000 & 0.000 & 0.000 & 0.000 & 0.000 & 0.000 \\
\hline
\end{tabular}

Note: (1) robust standard errors in parentheses (automatically computed and reported with p-weighted data), (2) longitudinal weighting factors were computed, (3) xtoverid is a generalized version of the Hausman test of fixed vs. random effects, (4) asterisks refer to significance levels: $* 10$-percent, ${ }^{* *} 5$-percent, $* * * 1$-percent levels.

Source: Socio-economic Panel (SOEP) (2010), own calculations.

In contrast, the coefficients associated with academic education (uni) subsequent to apprenticeship training are significant and positive in all specifications. The wage premiums

\footnotetext{
${ }^{87}$ These estimates are not presented in the appendix for reasons of space. Note though that in the West German estimations most dummies were highly statistically insignificant, while in the East German estimations the dummies were positive and significant.

${ }^{88}$ The estimates are converted according to the formula: $\% \Delta$ wage $\approx 100^{*}\left(\mathrm{e}^{\beta}-1\right)$.
} 
associated with investing in academic education are sizeable and range from 17.2 per cent (West German females) to 45.3 per cent (East German females). The premiums are thus up to eight times above that associated with further vocational education for West German men. Interestingly, the return to an academic certificate is considerably higher for persons living in East Germany. For East German males the coefficient is about one half above the estimate for West German males, whereas for East German females the estimate is more than twice as high compared to their West German counterparts.

Therefore, assuming that voc2 and uni mirror at least in part the two rather distinct types of further qualification in occupational areas which have undergone quite dissimilar structural changes as described by the developments in the craft and banking sectors, respectively, their corresponding return estimates seem to reflect these changes.

The interaction effect between the two types of post-school qualification indicates that acquiring both certificates results in either no statistically significant wage effect (West German males) or, in the case of females in either region, a sizeable wage penalty which more than overcompensates the positive main effects. Though politically desired, the persons in the sample who have actually undertaken the double investment of combining further vocational and academic education were not economically rewarded for their effort.

The other covariates mostly behaved as expected (see appendix). As regards the mobility indicators, current tenure had a significantly positive though small impact on West German female wages only. In contrast, in East Germany tenure positively affected both male and female wages. Moreover, for East German females a job promotion coincided with a significant wage increase. On the other hand, employer changes affected East German female wages even more strongly.

Results for the sample "all" which additionally includes persons in self-employment are summarized in TABLE $3 .^{89}$ Overall, the estimates of the returns to education are relatively robust to the inclusion of observations in which respondents are self-employed. However, for West German males the further vocational education coefficient has turned insignificant, while the estimate of the university education variable is considerably higher for males in East Germany compared to the sample "dependent".

Again, acquiring both further vocational and academic education is associated with a sizeable wage penalty for females in West and East Germany, whereas no significant wage effect can be observed for males. The self-employment indicators are even more heterogeneous. First, the dummy self indicates whether a change in individuals' employment status (to self-employment) affected their wage. There are significant though opposite effects for West German males and

${ }^{89}$ Estimation results for the other covariates are provided in the appendix. 
females. For the former the switch to becoming self-employed was beneficial, while the latter experienced a wage penalty. The East German results are somewhat reversed in that the wage effect is significantly positive and sizeable for females, while there is no significant impact for males.

Persons who both experienced variation in their level of education and their employment status contribute to the estimation of the interaction effects voc ${ }^{*}$ self and uni*self. Though mostly negative, the combined effects are statistically insignificant with the exception of uni* self for West German males. Even though the main effects are significant and positive, their combined effect was associated with a considerable wage drop for males living in West Germany.

TABLE 3 FIXED EFFECTS ESTIMATES OF SECOND POST-SCHOOL QUALIFICATION - SAMPLE "ALL"

\begin{tabular}{|c|c|c|c|c|c|c|}
\hline \multirow[b]{2}{*}{ Variables } & \multicolumn{3}{|c|}{ West } & \multicolumn{3}{|c|}{ East } \\
\hline & aggregate & males & females & aggregate & males & females \\
\hline \multicolumn{7}{|l|}{ 2nd post-school qualification } \\
\hline \multirow[t]{2}{*}{ further vocational (voc2) } & $\begin{array}{l}.0628 \\
(.0389)\end{array}$ & $\begin{array}{l}.0399 \\
(.0317)\end{array}$ & $\begin{array}{l}.1162 \\
(.0842)\end{array}$ & $\begin{array}{l}.0527 \\
(.0360)\end{array}$ & $\begin{array}{l}.0318 \\
(.0558)\end{array}$ & $\begin{array}{l}.0528 \\
(.0461)\end{array}$ \\
\hline & $\begin{array}{l}.1874 * * * \\
(.0496)\end{array}$ & $\begin{array}{l}.1997 * * * \\
(.0567)\end{array}$ & $\begin{array}{l}.1566^{* *} \\
(.0775)\end{array}$ & $\begin{array}{l}.4130^{* * *} \\
(.1124)\end{array}$ & $\begin{array}{l}.4314 * * * \\
(.1375)\end{array}$ & $\begin{array}{l}.3602^{* * *} \\
(.1222)\end{array}$ \\
\hline $\operatorname{voc} 2 *$ uni & $\begin{array}{l}-.3697 * * \\
(.1467)\end{array}$ & $\begin{array}{l}-.1357 \\
(.0867)\end{array}$ & $\begin{array}{l}-.5060^{* * *} \\
(.1326)\end{array}$ & $\begin{array}{l}-.5371 * * \\
(.2400)\end{array}$ & $\begin{array}{l}-.5527 \\
(.4959)\end{array}$ & $\begin{array}{l}-.5897 * * * \\
(.1348)\end{array}$ \\
\hline \multicolumn{7}{|l|}{ Self-employment indicators } \\
\hline self & $\begin{array}{l}.0610 \\
(.0942)\end{array}$ & $\begin{array}{l}.1542^{*} \\
(.0891)\end{array}$ & $\begin{array}{l}-.2035^{*} \\
(.1083)\end{array}$ & $\begin{array}{l}-.0058 \\
(.0860)\end{array}$ & $\begin{array}{l}-.1275 \\
(.0840)\end{array}$ & $\begin{array}{l}.2160^{*} \\
(.1199)\end{array}$ \\
\hline voc $2 *$ self & $\begin{array}{l}-.1519 \\
(.1002)\end{array}$ & $\begin{array}{l}-.1538 \\
(.1166)\end{array}$ & $\begin{array}{l}-.0832 \\
(.1532)\end{array}$ & $\begin{array}{l}-.1211 \\
(.1432)\end{array}$ & $\begin{array}{l}-.0045 \\
(.1337)\end{array}$ & $\begin{array}{l}-.3077 \\
(.3500)\end{array}$ \\
\hline uni*self & $\begin{array}{l}-.2275 \\
(.1654) \\
\end{array}$ & $\begin{array}{l}-.5294^{* * *} \\
(.1076) \\
\end{array}$ & $\begin{array}{l}-.1176 \\
(.1156) \\
\end{array}$ & $\begin{array}{l}-.0631 \\
(.3811) \\
\end{array}$ & $\begin{array}{l}.0523 \\
(.4221) \\
\end{array}$ & no obs \\
\hline \multicolumn{7}{|l|}{ Observations $/ \mathrm{R}^{2}$} \\
\hline $\mathrm{N}$ & 59,662 & 34,253 & 25,409 & 19,151 & 10,764 & 8,387 \\
\hline within $\mathrm{R}^{2}$ & 0.131 & 0.157 & 0.121 & 0.082 & 0.086 & 0.109 \\
\hline \multicolumn{7}{|l|}{ Specification test: xtoverid } \\
\hline Sargan-Hansen statistic & 687.331 & 388.169 & 273.005 & 401.590 & 251.862 & 265.088 \\
\hline $\mathrm{p}$-value & 0.000 & 0.000 & 0.000 & 0.000 & 0.000 & 0.000 \\
\hline
\end{tabular}

Note: (1) robust standard errors in parentheses (automatically computed and reported with p-weighted data), (2) longitudinal weighting factors were computed, (3) xtoverid is a generalized version of the Hausman test of fixed vs. random effects, (4) asterisks refer to significance levels: $* 10$-percent, $* * 5$-percent, ${ }^{* * *} 1$-percent levels.

Source: Socio-economic Panel (SOEP) (2010), own calculations.

Finally, estimates are provided for the sample "self" which is restricted to observations in which the respondents reported to be self-employed (TABLE 4). Thus, in contrast to the sample "all", there are no observations from persons who change their employment status during the period of observation. The interaction term voc2uni was dropped from the estimation, because there was only one observation. Moreover, only aggregate results are presented to make the estimates more 
reliable. Overall, the linear unobserved effects model and the choice of covariates seem less suitable to analyze the wage determinants of the self-employed. ${ }^{90}$

The point estimate of the return to further vocational education is positive and similar to those of the West and East aggregates in the previous results. However, again similar to the other specifications, there is no statistically significant wage or income effect for the self-employed who obtained a Master craftsperson, technician or equivalent certificate compared to not having obtained this further education. The return to acquiring an academic degree is even negative and highly statistically significant. The associated income drop is in the order of 25.4 per cent. Thus, given a sufficient reliability of the estimates, entrepreneurial success in the form of higher turnover and personal income is not necessarily caused by further investments in education subsequent to initial vocational education. At least, for the self-employed in the samples, no such causality could be observed.

\section{TABLE 4 FIXED EFFECTS ESTIMATES OF SECOND POST-SCHOOL QUALIFICATION - SAMPLE "SELF”}

\begin{tabular}{|c|c|}
\hline Variables & Germany \\
\hline \multicolumn{2}{|l|}{ 2nd post-school qualification } \\
\hline \multirow[t]{2}{*}{ further vocational (voc2) } & $\begin{array}{c}.0672 \\
(.1417)\end{array}$ \\
\hline & $\begin{array}{c}-.2263^{* * *} \\
(.0599)\end{array}$ \\
\hline \multicolumn{2}{|l|}{ Observations/ $\mathrm{R}^{2}$} \\
\hline $\mathrm{N}$ & 4,575 \\
\hline within $\mathrm{R}^{2}$ & 0.042 \\
\hline \multicolumn{2}{|l|}{ Specification test: $x$ toverid } \\
\hline Sargan-Hansen statistic & 126.853 \\
\hline p-value & 0.000 \\
\hline
\end{tabular}

Note: (1) robust standard errors in parentheses (automatically computed and reported with p-weighted data), (2) longitudinal weighting factors were computed, (3) xtoverid is a generalized version of the Hausman test of fixed vs. random effects, (4) asterisks refer to significance levels: * 10-percent, $* * 5$ percent, $* * * 1$-percent levels.

Source: Socio-economic Panel (SOEP) (2010), own calculations.

\section{CONCLUSION}

Given the challenges posed by the concepts of life-long learning and technological change on the one hand, and the sustained quantitative dominance of the apprenticeship system in the provision of post-school qualifications on the other hand, post-apprenticeship investments in further education and thus the general role of sequences of formal qualifications in individuals' educational biographies necessarily increase in the future. While recent political initiative has

\footnotetext{
${ }^{90}$ Most of the covariates are statistically insignificant (see appendix).
} 
explicitly recognized this necessity and expanded the promotion of post-apprenticeship human capital investments both at the vocational and academic levels, past developments in the apprenticeship system and the corresponding evolution of further education options in the economy partly tell a different story as the examples of the craft and banking sectors have shown. More specifically, it could be observed that purely vocational paths have lost significance in more traditional occupations in both the craft and industry sectors, while the anecdotal evidence and the SOEP data suggest that mixed vocational and academic paths are increasingly important in both commercial and technical occupations.

Against this background, this paper evaluated the wage effects of post-apprenticeship investments in formal qualifications at the vocational and academic levels in Germany. Longitudinal data from the SOEP were used to estimate these returns. Tests of overidentifying restrictions of fixed vs. random effects suggested the endogeneity of the regressors and thus the presence of unobserved individual specific effects in all specifications. Therefore, the wage equations were estimated with fixed effects.

Overall, the diverging patterns of the two most important post-school educational paths are reflected in the return estimates of both types of further education. Except for West German males, there is no significant return to further vocational education, while the returns to postapprenticeship university education are significantly positive and sizeable. Moreover, combinations of further vocational and academic education are associated with a strong wage penalty in almost all specifications.

Therefore, though politically and socially desired, the public promotion of further vocational education options, most notably the Master craftsperson qualification, seems less justified on economic grounds since the return estimates show that the investment is not profitable. Human capital theory suggests that the investment did not raise individuals' productivity (in their current job) or that individuals are not paid according to their (increased) productivity. Over-capacities of individuals with an industry master qualification (foreman) on the one hand and the decline in corresponding foreman positions in the manufacturing industry (Plicht, 2000) provide evidence for both suggestions. Similarly, the facilitated access for persons with qualifications other than the Master craftsperson certificate to the craft sector and the reduction of trades liable to registration may have contributed to "devaluating" the Master craftsperson qualification.

Therefore, purely vocational paths of post-school qualifications do not increase individuals' income mobility and their potential to advance economically. However, they may contribute to sustaining their employability. 
Angrist, J. D.; Newey, W. K. (1991), Over-identification tests in earnings functions with fixed effects, Journal of Business and Economic Statistics, 9(3), pp. 317-323.

Autorengruppe Bildungsberichterstattung (ed.) (2010), Bildung in Deutschland 2010, Bielefeld: W. Bertelsmann Verlag GmbH \& Co. KG.

Baethge, M.; Solga, H.; Wieck, M. (2007), Berufsbildung im Umbruch: Signale eines überfälligen Aufbruchs, Studie: Friedrich-Ebert-Stiftung, Bonn, electronic edition: http://library.fes.de/pdffiles/stabsabteilung/04258/.

Baltagi, B. H.; Khanti-Akom, S. (1990), On efficient estimation with panel data: an empirical comparison of instrumental variables estimators, Journal of Applied Econometrics, 5(4), pp. 401-406.

Baum, C. F. (2006), An introduction to modern econometrics using Stata, Stata Press, College Station, Texas.

Becker, G. S. (1964), Human capital: A theoretical and empirical analysis, with special reference to education, New York: National Bureau of Economic Research.

Blundell, R.; Dearden, L.; Sianesi, B. (2005), Evaluating the effect of education on earnings: models, methods and results from the National Child Development Survey, Journal of the Royal Statistical Society, 168(3), pp. 473-512.

Bundesinstitut für Berufsbildung (ed.) (2009), Datenreport zum Berufsbildungsbericht 2009, Bonn: Bundesinstitut für Berufsbildung.

Bundesministerium für Bildung und Forschung (ed.) (2008), Aufstieg durch Bildung Qualifizierungsinitiative der Bundesregierung, Bonn, Berlin.

Büchel, F.; Pannenberg, M. (2004), Berufliche Weiterbildung in West- und Ostdeutschland Teilnehmer, Struktur und individueller Ertrag, Zeitschrift für Arbeitsmarktforschung, 37(2), pp. 73126.

Card, D. (2001), Estimating the return to schooling: progress on some persistent econometric problems, Econometrica, 69(5), pp. 1127-60.

Card, D. (1999), The causal effect of education on earnings, in: Ashenfelter, O.; Card, D. (ed.), Handbook of Labor Economics, Volume 3A, Elsevier Science, Amsterdam et al., pp. 1801-1863.

Cornwell, C.; Rupert, P. (1988), Efficient estimation with panel data: an empirical comparison of instrumental variables estimators, Journal of Applied Econometrics, 3(2), pp. 149-155. 
Dearden, L.; McIntosh, S. et al. (2002), The returns to academic and vocational qualifications in Britain, Bulletin of Economic Research, 54(3), pp. 249-274.

Desktop Companion to the German Socio-economic Panel (SOEP) (2005), edited by: HaiskenDeNew, J.; Frick, J. R., Version 8.0: Dec 2005.

Finegold, D.; Wagner, K. (2002), Are apprenticeships still relevant in the $21^{\text {st }}$ century? A case study of changing youth training arrangements in German banks, Industrial and Labor Relations Review, 55(4), pp. 667-685.

Flossmann, A. L.; Pohlmeier, W. (2006), Causal returns to education: a survey on empirical evidence for Germany, Jabrbücher für Nationalökonomie und Statistik, 226(1), pp. 6-23.

Franz, W.; Soskice, D. (1995), The German apprenticeship system, in: Buttler, F.; Franz, W. et al. (ed.), Institutional frameworks and labor market performance - Comparative views on the U.S. and German economies, Routledge: London, N.Y., pp. 208-234.

Griliches, Z. (1977), Estimating the Returns to Schooling: Some Econometric Problems, Econometrica, 45(1), pp. 1-22.

Harhoff, D.; Kane, T. J. (1997); Is the German apprenticeship system a panacea for the U.S. labor market?, Journal of Population Economics, 10(2), pp. 171-196.

Hausman, J. A. (1978), Specification tests in econometrics, Econometrica, 46(6), pp. 1251-1271.

Hausman, J. A.; Taylor, W. E. (1981), Panel data and unobservable individual effects, Econometrica, 49(6), pp. 1377-1398.

Haverkamp, K.; Sölter, A.; Kröger, J. (2009), Humankapitalbildung und Beschäftigungsperspektiven im Handwerk, Göttinger Handwerkswirtschaftliche Studien, 79, Mecke: Duderstadt.

Heckman, J. J.; Lalonde, R. J.; Smith, J. A. (1999), The economics and econometrics of active labor market programs, in: Ashenfelter, Orley; Card, David (ed.), Handbook of Labor Economics, Volume 3A, Elsevier Science, Amsterdam et al., pp. 1865-2097.

Heckman; J. J. and Hotz, V. J. (1989), Choosing among alternative nonexperimental methods for estimating the impact of social programs: the case of manpower training, Journal of the American Statistical Association, 84(408), pp. 862-874.

Henninges, H. v. (1994), Die berufliche, sektorale und statusmäßige Umverteilung von Facharbeitern, Beiträge zur Arbeitsmarkt- und Berufsforschung, BeitrAB 182, Nürnberg.

Imbens, G. W.; Wooldridge, J. M. (2009), Recent developments in the econometrics of program evaluation, Journal of Economic Literature, 47(1), pp. 5-86. 
Kalwij, A. (2000), Estimating the economic return to schooling on the basis of panel data, Applied Economics, 32(1), pp. 61-71.

Kuckulenz, A. (2007), Studies on continuing vocational training in Germany, ZEW Economic Studies, Vol. 37, Physica-Verlag: Heidelberg.

Lagemann, B.; Dürig, W. et al. (2004), Determinanten des Strukturwandels im Handwerk Zusammenfassung der Ergebnisse eines Forschungsprojekts, RWI:Materialien, Heft 14, Essen.

Mincer, J. (1974), Schooling, experience, and earnings, New York: National Bureau of Economic Research.

Müller, K. (2006), Erste Auswirkungen der Novellierung der Handwerksordnung von 2004, Göttinger Handwerkswirtschaftliche Studien, 74, Mecke: Duderstadt.

Neubäumer, R. (1991), Betriebliche Ausbildung „über Bedarf“ und Arbeitsmarktchancen Empirische Ergebnisse und ein Humankapitaltheoretischer Ansatz, Arbeitskreis Sozialwissenschaftliche Arbeitsmarktforschung (SAMF) e.V., Arbeitspapier 1991-1, Paderborn.

Niederalt, M. (2004), Zur ökonomischen Analyse betrieblicher Lehrstellenangebote in der Bundesrepublik Deutschland, Europäische Hochschulschriften, Vol. 3082, Peter Lang: Frankfurt a.M. et al.

Pfeiffer, F. (1997), Die Alterung des Ausbildungswissens nach der Handwerkslehre, in: Seminar für Handwerkswesen (ed.), Der Faktor Humankapital im Handwerk, Kontaktstudium Wirtschaftswissenschaft 1996, Verlag Mecke Druck: Duderstadt, pp. 75-107.

Pfeiffer, F.; Blechinger, D. (1995), Verwertbarkeit der Berufsausbildung im technischen Wandel, in: Franz, W.; Steiner, V. (ed.), Der westdeutsche Arbeitsmarkt im strukturellen Anpassungsprozess, ZEWWirtschaftsanalysen, Vol. 39, Baden-Baden, pp. 105-140.

Piscke, J.-S. (2001), Continuous Training in Germany, Journal of Population Economics, 14(3), pp. 523-548.

Plicht, H. (2000), Zur Zukunft von Meister- und Technikerpositionen im Verarbeitenden Gewerbe, Beiträge zur Arbeitsmarkt- und Berufsforschung, BeitrAB 233, Nürnberg.

Rubin, D. B. (1974), Estimating causal effects of treatments in randomized and nonrandomized studies, Journal of Educational Psychology, 66(3), pp. 688-701.

Schaffer, M. E., Stillman, S. (2010), xtoverid: Stata module to calculate tests of overidentifying restrictions after xtreg, xtivreg, xtivreg2 and xthtaylor, http://ideas.repec.org/c/boc/bocode/s456779.html 
Skarupke, R. (2005), Renditen von Bildungsinvestitionen - Paneldatenschätrungen für die Bundesrepublik Deutschland. Schriften zur Empirischen Wirtschaftsforschung, Band 6, Peter Lang: Frankfurt a.M. et al.

Soskice, D. (1994), Reconciling markets and institutions: The German apprenticeship system, in: Lynch, L. M. (ed.), Training and the private sector - International comparisons, The University of Chicago Press: Chicago, London, pp. 25-60.

Statistisches Bundesamt (2010), Bildung und Kultur - Berufliche Bildung 2009, Fachserie 11 Reihe 3, Statistisches Bundesamt: Wiesbaden.

Steedman, H. (1993), The economics of youth training in Germany, The Economic Journal, 103(420), pp. 1279-1291.

Unabhängige Expertenkommission „Finanzierung Lebenslangen Lernens“ (2004), Schlussbericht der unabhängigen Expertenkommission „Finanzierung Lebenslangen Lernens“: Der Weg in die Zukunft, 28.Juli 2004, http://www.bmbf.de/pub/schlussbericht kommission lll.pdf (retrieved 12/14/2010).

Wagner, J.; Lorenz, W. (1989), Einkommensfunktionsschätzungen mit Längsschnittdaten für vollzeiterwerbstätige deutsche Männer, Konjunkturpolitik, 35(1-2), pp. 99-109.

Wooldridge; J. M. (2010), Econometric Analysis of Cross Section and Panel Data, The MIT Press: Cambridge, London, second edition. 
APPENDIX 


\section{A.1 QUALIFICATION AND CAREER SURVEY}

The Qualification and Career Survey $(\mathrm{QaC})$ is a repeated and comprehensive cross-sectional survey of gainfully employed persons in Germany provided by the Federal Institute for Vocational Education and Training (BiBB). ${ }^{91}$ The most recent wave was carried out in 2005/2006 in cooperation with the Federal Institute for Occupational Safety and Health (BAuA). Previous surveys were cooperative works between the BiBB and the Institute for Employment Research (IAB) and were conducted in 1979, 1985/1986, 1991/1992 and 1998/1999. ${ }^{92}$

We use data from the latest survey available. The $\mathrm{QaC}$ is a $0.1 \%$-sample of all gainfully employed persons in Germany ${ }^{93}$ and is representative of all individuals in paid employment who are at least 15 years old and work at least 10 hours per week. ${ }^{94}$

The $\mathrm{QaC}$ is known for its comprehensive information about the job respondents held at the time of the interview, e.g. workload, tools used, task-related issues, health-related issues, job conditions etc. Moreover, the survey provides detailed accounts of (almost) all formal qualifications, school and post-school, (ever) attained by respondents. More specifically, post-school achievement (vocational and academic) is reported up to a maximum of five formal post-school qualifications. Respondents are asked about their educational attainment in so-called "education loops". There is a maximum of five loops and the last loop contains the most recent formal qualification acquired. $^{95}$

The raw sample contains 20,000 persons which we adjusted for persons with incomplete or improperly specified educational biographies. More specifically, we dropped persons who did not report their first or last qualification (loop), reported further vocational education as their first qualification $^{96}$, reported to have completed civil service training without further specification (level of training) or reported "other" qualification in any of the education loops. For our descriptive analysis we could thus use information from 18,464 respondents. The data were weighted with a structural weight as provided in the data set. ${ }^{97}$

\footnotetext{
91 Scientific-use-files of the data are made available by the Datenarchiv für Sozialwissenschaften (formerly: Zentralarchiv für empirische Sozialforschung, ZA), a department of GESIS - Leibnitz-Institut für Sozialwissenschaften. The archive does not bear any responsibility regarding the analysis and interpretation of the data in this paper.

${ }^{92}$ The 1979 and 1991/1992 (East Germany only) surveys include unemployed persons.

93 Dostal, W.; Jansen, R. (2002), Qualifikation und Erwerbssituation in Deutschland. 20 Jahre BiBB/IABErhebungen, Mitteilungen aus der Arbeitsmarkt- und Berufsforschung, 35(2), pp. 232-253.

${ }^{94}$ The definition of gainful employment includes helping family members (mithelfende Familienangehörige), persons on maternity/parental leave etc. whose absence does not exceed three months and migrants whose German is sufficient to participate in the survey. In contrast, apprentices and volunteer workers were excluded from the survey. ${ }^{95}$ If a respondent acquired more than five formal qualifications, the most recent will be counted in the fifth loop. Consequently, this person's educational biography will not be complete. However, the share of persons who reported five post-school qualifications is a negligible 0.05 per cent in our sample.

${ }^{96}$ Normally, the acquisition of a further vocational education certificate (Master craftsman certificate and equivalent) is conditional on the prior completion of initial vocational education.

${ }_{97}$ Since percentages are the focus of the descriptive analysis, Stata's aweight command seemed most suitable.
} 
Three levels of post-school qualifications are distinguished: initial vocational education, further vocational education and academic education. The first category includes persons with apprenticeship training, full-time vocational schooling and civil service training at the basic or middle level. The further vocational education category comprises persons with a Master craftsperson certificate, technicians and Fachwirte, while academic education includes degrees from a university of applied science and other university-level institutions, upper and higher level service training and persons who graduated from a Berufsakademie.

TABLE A1 SUMMARY STATISTICS OF SAMPLE "DEPENDENT" BY SAMPLING REGION

\begin{tabular}{|c|c|c|c|c|c|c|c|c|c|}
\hline \multirow[b]{2}{*}{ Variables } & & \multicolumn{4}{|c|}{ West } & \multicolumn{4}{|c|}{ East } \\
\hline & & Mean & Std. Dev. & Min & Max & Mean & Std. Dev. & Min & Max \\
\hline \multicolumn{10}{|l|}{ Wage } \\
\hline log hourly wage & overall & 2.56 & 0.41 & -1.14 & 6.73 & 2.17 & 0.38 & -0.92 & 5.04 \\
\hline & between & & 0.36 & 0.48 & 4.13 & & 0.33 & 0.38 & 3.43 \\
\hline & within & & 0.25 & -0.33 & 5.96 & & 0.23 & -0.33 & 4.46 \\
\hline \multicolumn{10}{|l|}{ 2nd post-school qualification } \\
\hline \multirow[t]{3}{*}{ further vocational (voc2) } & overall & 0.03 & 0.18 & 0.00 & 1.00 & 0.03 & 0.16 & 0.00 & 1.00 \\
\hline & between & & 0.11 & 0.00 & 0.96 & & 0.10 & 0.00 & 0.92 \\
\hline & within & & 0.11 & -0.93 & 0.97 & & 0.10 & -0.90 & 0.93 \\
\hline \multirow[t]{3}{*}{ academic (uni) } & overall & 0.01 & 0.08 & 0.00 & 1.00 & 0.004 & 0.06 & 0.00 & 1.00 \\
\hline & between & & 0.06 & 0.00 & 0.95 & & 0.04 & 0.00 & 0.94 \\
\hline & within & & 0.05 & -0.94 & 0.95 & & 0.04 & -0.94 & 0.89 \\
\hline \multirow[t]{3}{*}{$\operatorname{voc} 2 *$ uni } & overall & 0.00 & 0.02 & 0.00 & 1.00 & 0.00 & 0.02 & 0.00 & 1.00 \\
\hline & between & & 0.01 & 0.00 & 0.82 & & 0.01 & 0.00 & 0.50 \\
\hline & within & & 0.01 & -0.82 & 0.90 & & 0.02 & -0.50 & 0.50 \\
\hline \multicolumn{10}{|c|}{ Total work experience (full- and part-time) } \\
\hline \multirow[t]{3}{*}{$\exp$} & overall & 17.76 & 10.85 & 0.00 & 51.00 & 18.30 & 10.31 & 0.00 & 46.00 \\
\hline & between & & 11.10 & 0.25 & 47.50 & & 10.75 & 0.00 & 46.00 \\
\hline & within & & 4.03 & 1.82 & 37.76 & & 3.41 & 7.63 & 30.55 \\
\hline \multirow[t]{3}{*}{$\exp 2$} & overall & 433.08 & 445.42 & 0.00 & $2,601.0$ & 441.03 & 415.07 & 0.00 & $2,116.0$ \\
\hline & between & & 445.98 & 0.09 & $2,556.5$ & & 416.78 & 0.00 & $2,116.0$ \\
\hline & within & & 167.69 & -536.80 & $1,958.9$ & & 143.71 & -178.01 & $1,153.5$ \\
\hline \multicolumn{10}{|l|}{ Working in civil service } \\
\hline \multirow[t]{3}{*}{ civilservice } & overall & 0.02 & 0.14 & 0.00 & 1.00 & 0.01 & 0.10 & 0.00 & 1.00 \\
\hline & between & & 0.13 & 0.00 & 1.00 & & 0.10 & 0.00 & 1.00 \\
\hline & within & & 0.05 & -0.94 & 0.98 & & 0.04 & -0.88 & 0.95 \\
\hline \multicolumn{10}{|l|}{ Mobility indicators } \\
\hline \multirow[t]{3}{*}{ occupational change } & overall & 0.19 & 0.40 & 0.00 & 1.00 & 0.24 & 0.43 & 0.00 & 1.00 \\
\hline & between & & 0.19 & 0.00 & 1.00 & & 0.22 & 0.00 & 1.00 \\
\hline & within & & 0.36 & -0.68 & 1.16 & & 0.38 & -0.56 & 1.18 \\
\hline \multirow[t]{3}{*}{ number of employer changes } & overall & 0.51 & 0.80 & 0.00 & 7.00 & 0.62 & 0.80 & 0.00 & 5.00 \\
\hline & between & & 0.64 & 0.00 & 4.00 & & 0.65 & 0.00 & 4.00 \\
\hline & within & & 0.37 & -3.35 & 3.77 & & 0.40 & -2.26 & 3.29 \\
\hline \multirow[t]{3}{*}{ current tenure } & overall & 11.15 & 9.74 & 0.00 & 50.90 & 9.17 & 8.94 & 0.00 & 50.30 \\
\hline & between & & 9.29 & 0.00 & 47.94 & & 8.09 & 0.00 & 46.66 \\
\hline & within & & 3.82 & -17.79 & 36.04 & & 3.93 & -24.61 & 37.27 \\
\hline \multirow[t]{3}{*}{ promotion } & overall & 0.11 & 0.31 & 0.00 & 1.00 & 0.10 & 0.30 & 0.00 & 1.00 \\
\hline & between & & 0.14 & 0.00 & 1.00 & & 0.14 & 0.00 & 1.00 \\
\hline & within & & 0.29 & -0.64 & 1.07 & & 0.28 & -0.65 & 1.05 \\
\hline
\end{tabular}


TABLE A1 (ctd.) SUMMARY STATISTICS OF SAMPLE “DEPENDENT" BY SAMPLING REGION

\begin{tabular}{|c|c|c|c|c|c|c|c|c|c|}
\hline \multirow[b]{2}{*}{ Variables } & & \multicolumn{4}{|c|}{ West } & \multicolumn{4}{|c|}{ East } \\
\hline & & Mean & Std. Dev. & Min & Max & Mean & Std. Dev. & Min & Max \\
\hline \multicolumn{10}{|l|}{ Economic sectors } \\
\hline \multirow[t]{3}{*}{ agriculture } & overall & 0.01 & 0.08 & 0.00 & 1.00 & 0.04 & 0.19 & 0.00 & 1.00 \\
\hline & between & & 0.07 & 0.00 & 1.00 & & 0.17 & 0.00 & 1.00 \\
\hline & within & & 0.05 & -0.91 & 0.97 & & 0.10 & -0.85 & 0.98 \\
\hline \multirow[t]{3}{*}{ industry } & overall & 0.36 & 0.48 & 0.00 & 1.00 & 0.26 & 0.44 & 0.00 & 1.00 \\
\hline & between & & 0.43 & 0.00 & 1.00 & & 0.38 & 0.00 & 1.00 \\
\hline & within & & 0.22 & -0.60 & 1.32 & & 0.23 & -0.68 & 1.21 \\
\hline \multirow[t]{3}{*}{ construction } & overall & 0.08 & 0.27 & 0.00 & 1.00 & 0.13 & 0.34 & 0.00 & 1.00 \\
\hline & between & & 0.24 & 0.00 & 1.00 & & 0.30 & 0.00 & 1.00 \\
\hline & within & & 0.13 & -0.89 & 1.04 & & 0.18 & -0.81 & 1.07 \\
\hline \multirow[t]{3}{*}{ banking, insurance } & overall & 0.07 & 0.26 & 0.00 & 1.00 & 0.04 & 0.19 & 0.00 & 1.00 \\
\hline & between & & 0.23 & 0.00 & 1.00 & & 0.15 & 0.00 & 1.00 \\
\hline & within & & 0.09 & -0.88 & 1.02 & & 0.08 & -0.85 & 0.98 \\
\hline \multirow[t]{3}{*}{ services } & overall & 0.31 & 0.46 & 0.00 & 1.00 & 0.35 & 0.48 & 0.00 & 1.00 \\
\hline & between & & 0.42 & 0.00 & 1.00 & & 0.42 & 0.00 & 1.00 \\
\hline & within & & 0.22 & -0.65 & 1.27 & & 0.23 & -0.60 & 1.29 \\
\hline \multirow[t]{3}{*}{ public administration } & overall & 0.18 & 0.38 & 0.00 & 1.00 & 0.17 & 0.37 & 0.00 & 1.00 \\
\hline & between & & 0.37 & 0.00 & 1.00 & & 0.36 & 0.00 & 1.00 \\
\hline & within & & 0.13 & -0.79 & 1.14 & & 0.13 & -0.79 & 1.13 \\
\hline \multicolumn{10}{|l|}{ Firm size } \\
\hline \multirow[t]{3}{*}{$<20$} & overall & 0.23 & 0.42 & 0.00 & 1.00 & 0.28 & 0.45 & 0.00 & 1.00 \\
\hline & between & & 0.39 & 0.00 & 1.00 & & 0.38 & 0.00 & 1.00 \\
\hline & within & & 0.22 & -0.73 & 1.19 & & 0.26 & -0.67 & 1.23 \\
\hline \multirow[t]{3}{*}{20 to $<200$} & overall & 0.28 & 0.45 & 0.00 & 1.00 & 0.36 & 0.48 & 0.00 & 1.00 \\
\hline & between & & 0.38 & 0.00 & 1.00 & & 0.38 & 0.00 & 1.00 \\
\hline & within & & 0.27 & -0.68 & 1.24 & & 0.32 & -0.58 & 1.31 \\
\hline \multirow[t]{3}{*}{200 to $<2,000$} & overall & 0.24 & 0.42 & 0.00 & 1.00 & 0.20 & 0.40 & 0.00 & 1.00 \\
\hline & between & & 0.35 & 0.00 & 1.00 & & 0.31 & 0.00 & 1.00 \\
\hline & within & & 0.25 & -0.73 & 1.20 & & 0.26 & -0.75 & 1.15 \\
\hline \multirow[t]{3}{*}{$2,000+$} & overall & 0.25 & 0.43 & 0.00 & 1.00 & 0.16 & 0.36 & 0.00 & 1.00 \\
\hline & between & & 0.37 & 0.00 & 1.00 & & 0.31 & 0.00 & 1.00 \\
\hline & within & & 0.22 & -0.71 & 1.21 & & 0.20 & -0.79 & 1.10 \\
\hline \multirow[t]{3}{*}{ Observations } & $N$ & 55,746 & & & & 18,019 & & & \\
\hline & $n$ & 7,447 & & & & 2,656 & & & \\
\hline & T-bar & 7.486 & & & & 6.784 & & & \\
\hline
\end{tabular}

Source: Socio-economic Panel (SOEP) (2010), own calculations. 
TABLE A2 SUMMARY STATISTICS OF SAMPLE “ALL” BY SAMPLING REGION

\begin{tabular}{|c|c|c|c|c|c|c|c|c|c|}
\hline \multirow[b]{2}{*}{ Variables } & & \multicolumn{4}{|c|}{ West } & \multicolumn{4}{|c|}{ East } \\
\hline & & Mean & Std. Dev. & Min & Max & Mean & Std. Dev. & Min & Max \\
\hline \multicolumn{10}{|l|}{$\begin{array}{l}\text { Wage } \\
\text { Tag }\end{array}$} \\
\hline log hourly wage & overall & 2.56 & 0.45 & -1.14 & 6.73 & 2.16 & 0.42 & -1.19 & 5.04 \\
\hline & between & & 0.40 & -0.07 & 4.13 & & 0.35 & -0.06 & 3.49 \\
\hline & within & & 0.27 & -0.39 & 5.95 & & 0.26 & -0.94 & 4.45 \\
\hline \multicolumn{10}{|l|}{ 2nd post-school qualification } \\
\hline \multirow[t]{3}{*}{ further vocational (voc2) } & overall & 0.03 & 0.18 & 0.00 & 1.00 & 0.03 & 0.17 & 0.00 & 1.00 \\
\hline & between & & 0.11 & 0.00 & 0.96 & & 0.11 & 0.00 & 0.92 \\
\hline & within & & 0.11 & -0.93 & 0.97 & & 0.11 & -0.93 & 0.93 \\
\hline \multirow[t]{3}{*}{ academic (uni) } & overall & 0.01 & 0.08 & 0.00 & 1.00 & 0.004 & 0.07 & 0.00 & 1.00 \\
\hline & between & & 0.06 & 0.00 & 0.95 & & 0.04 & 0.00 & 0.94 \\
\hline & within & & 0.05 & -0.94 & 0.95 & & 0.04 & -0.94 & 0.89 \\
\hline \multirow[t]{3}{*}{ voc $2 *$ uni } & overall & 0.00 & 0.02 & 0.00 & 1.00 & 0.001 & 0.03 & 0.00 & 1.00 \\
\hline & between & & 0.01 & 0.00 & 0.82 & & 0.02 & 0.00 & 0.64 \\
\hline & within & & 0.01 & -0.82 & 0.95 & & 0.02 & -0.64 & 0.50 \\
\hline \multicolumn{10}{|l|}{ Self-employment indicators } \\
\hline \multirow[t]{3}{*}{ self } & overall & 0.06 & 0.24 & 0.00 & 1.00 & 0.06 & 0.23 & 0.00 & 1.00 \\
\hline & between & & 0.23 & 0.00 & 1.00 & & 0.21 & 0.00 & 1.00 \\
\hline & within & & 0.12 & -0.89 & 1.02 & & 0.11 & -0.88 & 1.00 \\
\hline \multirow[t]{3}{*}{$\operatorname{voc} 2 *$ self } & overall & 0.003 & 0.06 & 0.00 & 1.00 & 0.01 & 0.07 & 0.00 & 1.00 \\
\hline & between & & 0.03 & 0.00 & 0.86 & & 0.04 & 0.00 & 0.78 \\
\hline & within & & 0.04 & -0.86 & 0.95 & & 0.05 & -0.77 & 0.84 \\
\hline \multirow[t]{3}{*}{ uni*self } & overall & 0.00 & 0.02 & 0.00 & 1.00 & 0.001 & 0.02 & 0.00 & 1.00 \\
\hline & between & & 0.01 & 0.00 & 0.75 & & 0.01 & 0.00 & 0.64 \\
\hline & within & & 0.01 & -0.75 & 0.95 & & 0.02 & -0.75 & 0.95 \\
\hline \multicolumn{10}{|c|}{ Total work experience (full- and part-time) } \\
\hline \multirow[t]{3}{*}{$\exp$} & overall & 18.07 & 10.92 & 0.00 & 51.00 & 18.36 & 10.28 & 0.00 & 47.30 \\
\hline & between & & 11.24 & 0.25 & 50.50 & & 10.73 & 0.00 & 46.00 \\
\hline & within & & 4.08 & 3.07 & 38.07 & & 3.43 & 7.70 & 30.42 \\
\hline \multirow[t]{3}{*}{$\exp 2$} & overall & 445.73 & 453.92 & 0.00 & $2,601.0$ & 442.78 & 416.25 & 0.00 & $2,237.3$ \\
\hline & between & & 459.82 & 0.09 & $2,550.5$ & & 418.91 & 0.09 & $2,116.0$ \\
\hline & within & & 170.80 & -434.52 & $1,971.5$ & & 144.49 & -434.52 & $1,155.3$ \\
\hline \multicolumn{10}{|l|}{ Working in civil service } \\
\hline \multirow[t]{3}{*}{ civilservice } & overall & 0.02 & 0.13 & 0.00 & 1.00 & 0.01 & 0.10 & 0.00 & 1.00 \\
\hline & between & & 0.12 & 0.00 & 1.00 & & 0.09 & 0.00 & 1.00 \\
\hline & within & & 0.05 & -0.94 & 0.98 & & 0.04 & -0.88 & 0.95 \\
\hline \multicolumn{10}{|l|}{ Mobility indicator } \\
\hline \multirow[t]{3}{*}{ occupational change } & overall & 0.20 & 0.40 & 0.00 & 1.00 & 0.24 & 0.43 & 0.00 & 1.00 \\
\hline & between & & 0.20 & 0.00 & 1.00 & & 0.22 & 0.00 & 1.00 \\
\hline & within & & 0.36 & -0.68 & 1.16 & & 0.34 & -0.59 & 1.19 \\
\hline
\end{tabular}


TABLE A2 (ctd.) SUMMARY STATISTICS OF SAMPLE “ALL” BY SAMPLING REGION

\begin{tabular}{|c|c|c|c|c|c|c|c|c|c|}
\hline \multirow[b]{2}{*}{ Variables } & & \multicolumn{4}{|c|}{ West } & \multicolumn{4}{|c|}{ East } \\
\hline & & Mean & Std. Dev. & Min & Max & Mean & Std. Dev. & Min & $\operatorname{Max}$ \\
\hline \multicolumn{10}{|l|}{ Economic sectors } \\
\hline \multirow[t]{3}{*}{ agriculture } & overall & 0.01 & 0.11 & 0.00 & 1.00 & 0.04 & 0.19 & 0.00 & 1.00 \\
\hline & between & & 0.10 & 0.00 & 1.00 & & 0.17 & 0.00 & 1.00 \\
\hline & within & & 0.05 & -0.90 & 0.97 & & 0.10 & -0.85 & 0.98 \\
\hline \multirow[t]{3}{*}{ industry } & overall & 0.35 & 0.48 & 0.00 & 1.00 & 0.25 & 0.43 & 0.00 & 1.00 \\
\hline & between & & 0.42 & 0.00 & 1.00 & & 0.37 & 0.00 & 1.00 \\
\hline & within & & 0.22 & -0.61 & 1.31 & & 0.23 & -0.69 & 1.20 \\
\hline \multirow[t]{3}{*}{ construction } & overall & 0.08 & 0.27 & 0.00 & 1.00 & 0.14 & 0.34 & 0.00 & 1.00 \\
\hline & between & & 0.24 & 0.00 & 1.00 & & 0.30 & 0.00 & 1.00 \\
\hline & within & & 0.13 & -0.88 & 1.04 & & 0.18 & -0.81 & 1.07 \\
\hline \multirow[t]{3}{*}{ banking, insurance } & overall & 0.07 & 0.26 & 0.00 & 1.00 & 0.04 & 0.20 & 0.00 & 1.00 \\
\hline & between & & 0.23 & 0.00 & 1.00 & & 0.16 & 0.00 & 1.00 \\
\hline & within & & 0.09 & -0.88 & 1.02 & & 0.09 & -0.89 & 0.99 \\
\hline \multirow[t]{3}{*}{ services } & overall & 0.32 & 0.47 & 0.00 & 1.00 & 0.36 & 0.48 & 0.00 & 1.00 \\
\hline & between & & 0.43 & 0.00 & 1.00 & & 0.43 & 0.00 & 1.00 \\
\hline & within & & 0.23 & -0.64 & 1.28 & & 0.24 & -0.59 & 1.30 \\
\hline \multirow[t]{3}{*}{ public administration } & overall & 0.17 & 0.37 & 0.00 & 1.00 & 0.17 & 0.37 & 0.00 & 1.00 \\
\hline & between & & 0.36 & 0.00 & 1.00 & & 0.36 & 0.00 & 1.00 \\
\hline & within & & 0.13 & -0.79 & 1.13 & & 0.13 & -0.79 & 1.13 \\
\hline \multicolumn{10}{|l|}{ Firm size } \\
\hline \multirow[t]{3}{*}{$<20$} & overall & 0.28 & 0.45 & 0.00 & 1.00 & 0.32 & 0.47 & 0.00 & 1.00 \\
\hline & between & & 0.41 & 0.00 & 1.00 & & 0.40 & 0.00 & 1.00 \\
\hline & within & & 0.22 & -0.68 & 1.24 & & 0.26 & -0.63 & 1.26 \\
\hline \multirow[t]{3}{*}{20 to $<200$} & overall & 0.27 & 0.44 & 0.00 & 1.00 & 0.34 & 0.48 & 0.00 & 1.00 \\
\hline & between & & 0.37 & 0.00 & 1.00 & & 0.37 & 0.00 & 1.00 \\
\hline & within & & 0.27 & -0.70 & 1.23 & & 0.31 & -0.60 & 1.29 \\
\hline \multirow[t]{3}{*}{200 to $<2,000$} & overall & 0.22 & 0.41 & 0.00 & 1.00 & 0.19 & 0.39 & 0.00 & 1.00 \\
\hline & between & & 0.34 & 0.00 & 1.00 & & 0.30 & 0.00 & 1.00 \\
\hline & within & & 0.25 & -0.74 & 1.18 & & 0.26 & -0.76 & 1.14 \\
\hline \multirow[t]{3}{*}{$2,000+$} & overall & 0.24 & 0.42 & 0.00 & 1.00 & 0.15 & 0.36 & 0.00 & 1.00 \\
\hline & between & & 0.37 & 0.00 & 1.00 & & 0.30 & 0.00 & 1.00 \\
\hline & within & & 0.22 & -0.73 & 1.20 & & 0.20 & -0.80 & 1.10 \\
\hline \multirow[t]{3}{*}{ Observations } & $N$ & 59,662 & & & & 19,151 & & & \\
\hline & $n$ & 7,893 & & & & 2,787 & & & \\
\hline & $T$-bar & 7.559 & & & & 6.872 & & & \\
\hline
\end{tabular}

Source: Socio-economic Panel (SOEP) (2010), own calculations. 
TABLE A3 SUMMARY STATISTICS OF SAMPLE „SELF“

\begin{tabular}{|c|c|c|c|c|c|}
\hline \multirow[b]{2}{*}{ Variables } & & \multicolumn{4}{|c|}{ Germany } \\
\hline & & Mean & Std. Dev. & Min & Max \\
\hline \multicolumn{6}{|l|}{ Wage } \\
\hline \multirow[t]{3}{*}{ log hourly wage } & overall & 2.45 & 0.81 & -1.87 & 6.18 \\
\hline & between & & 0.72 & 0.07 & 4.51 \\
\hline & within & & 0.45 & -0.66 & 5.13 \\
\hline \multicolumn{6}{|l|}{ 2nd post-school qualification } \\
\hline \multirow[t]{3}{*}{ further vocational (voc2) } & overall & 0.03 & 0.18 & 0.00 & 1.00 \\
\hline & between & & 0.11 & 0.00 & 0.90 \\
\hline & within & & 0.11 & -0.87 & 0.97 \\
\hline \multirow[t]{3}{*}{ academic (uni) } & overall & 0.00 & 0.05 & 0.00 & 1.00 \\
\hline & between & & 0.03 & 0.00 & 0.75 \\
\hline & within & & 0.04 & -0.75 & 0.88 \\
\hline \multicolumn{6}{|c|}{ Total work experience (full- and part-time) } \\
\hline \multirow[t]{3}{*}{$\exp$} & overall & 22.41 & 10.75 & 0.00 & 51.00 \\
\hline & between & & 10.94 & 1.20 & 50.50 \\
\hline & within & & 3.38 & 8.45 & 37.17 \\
\hline \multirow[t]{3}{*}{$\exp 2$} & overall & 617.67 & 518.02 & 0.00 & $2,601.0$ \\
\hline & between & & 519.13 & 1.69 & $2,550.5$ \\
\hline & within & & 167.10 & -177.99 & $1,595.4$ \\
\hline \multicolumn{6}{|l|}{ Mobility indicator } \\
\hline \multirow[t]{3}{*}{ occupational change } & overall & 0.17 & 0.38 & 0.00 & 1.00 \\
\hline & between & & 0.20 & 0.00 & 1.00 \\
\hline & within & & 0.33 & -0.58 & 1.12 \\
\hline \multicolumn{6}{|l|}{ Economic sectors } \\
\hline \multirow[t]{3}{*}{ agriculture } & overall & 0.09 & 0.28 & 0.00 & 1.00 \\
\hline & between & & 0.26 & 0.00 & 1.00 \\
\hline & within & & 0.06 & -0.82 & 0.90 \\
\hline \multirow[t]{3}{*}{ industry } & overall & 0.14 & 0.34 & 0.00 & 1.00 \\
\hline & between & & 0.31 & 0.00 & 1.00 \\
\hline & within & & 0.19 & -0.78 & 1.06 \\
\hline \multirow[t]{3}{*}{ construction } & overall & 0.12 & 0.32 & 0.00 & 1.00 \\
\hline & between & & 0.28 & 0.00 & 1.00 \\
\hline & within & & 0.13 & -0.77 & 1.05 \\
\hline \multirow[t]{3}{*}{ banking, insurance } & overall & 0.11 & 0.31 & 0.00 & 1.00 \\
\hline & between & & 0.29 & 0.00 & 1.00 \\
\hline & within & & 0.10 & -0.78 & 1.03 \\
\hline \multirow[t]{3}{*}{ services } & overall & 0.50 & 0.50 & 0.00 & 1.00 \\
\hline & between & & 0.46 & 0.00 & 1.00 \\
\hline & within & & 0.22 & -0.43 & 1.43 \\
\hline \multirow[t]{3}{*}{ public administration } & overall & 0.05 & 0.23 & 0.00 & 1.00 \\
\hline & between & & 0.22 & 0.00 & 1.00 \\
\hline & within & & 0.10 & -0.78 & 0.94 \\
\hline
\end{tabular}


TABLE A3 (ctd.) SUMMARY STATISTICS OF SAMPLE „SELF“

\begin{tabular}{|c|c|c|c|c|c|c|}
\hline \multirow[b]{2}{*}{ Variables } & & & \multicolumn{4}{|c|}{ Germany } \\
\hline & & & Mean & Std. Dev. & Min & Max \\
\hline \multicolumn{7}{|l|}{ Firm size } \\
\hline & \multirow[t]{3}{*}{$<20$} & overall & 0.92 & 0.27 & 0.00 & 1.00 \\
\hline & & between & & 0.26 & 0.00 & 1.00 \\
\hline & & within & & 0.15 & -0.02 & 1.81 \\
\hline & \multirow[t]{3}{*}{20 to $<200$} & overall & 0.04 & 0.19 & 0.00 & 1.00 \\
\hline & & between & & 0.18 & 0.00 & 1.00 \\
\hline & & within & & 0.11 & -0.85 & 0.95 \\
\hline & \multirow[t]{3}{*}{200 to $<2,000$} & overall & 0.02 & 0.12 & 0.00 & 1.00 \\
\hline & & between & & 0.12 & 0.00 & 1.00 \\
\hline & & within & & 0.08 & -0.79 & 0.90 \\
\hline & \multirow[t]{3}{*}{$2,000+$} & overall & 0.03 & 0.17 & 0.00 & 1.00 \\
\hline & & between & & 0.15 & 0.00 & 1.00 \\
\hline & & within & & 0.10 & -0.86 & 0.97 \\
\hline \multirow[t]{3}{*}{ Observations } & & $\bar{N} N$ & $\overline{44,575}$ & & & \\
\hline & & n & 854 & & & \\
\hline & & T-bar & 5.357 & & & \\
\hline
\end{tabular}

Source: Socio-economic Panel (SOEP) (2010), own calculations. 
TABLE A4 RESPONDENTS' MEAN AGE AT TIME OF COMPLETING SECOND POST-SCHOOL QUALIFICATION

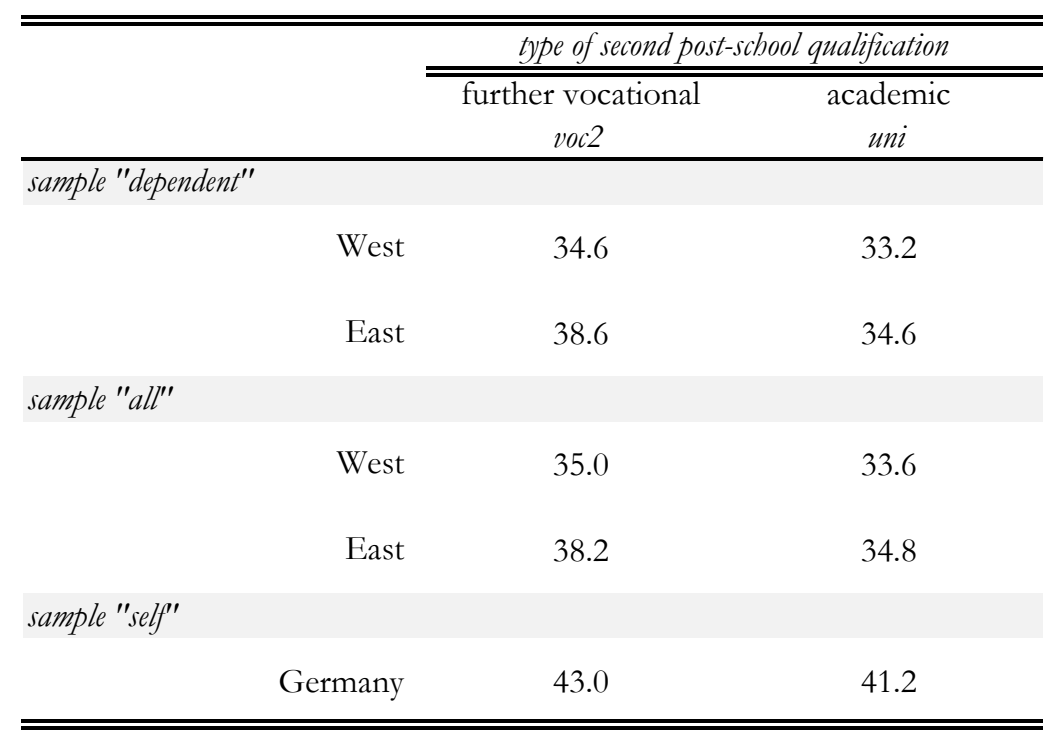

Source: Socio-economic Panel (SOEP) (2010), own calculations. 
TABLE A5 FIXED EFFECTS ESTIMATES OF COVARIATES, SAMPLE "DEPENDENT"

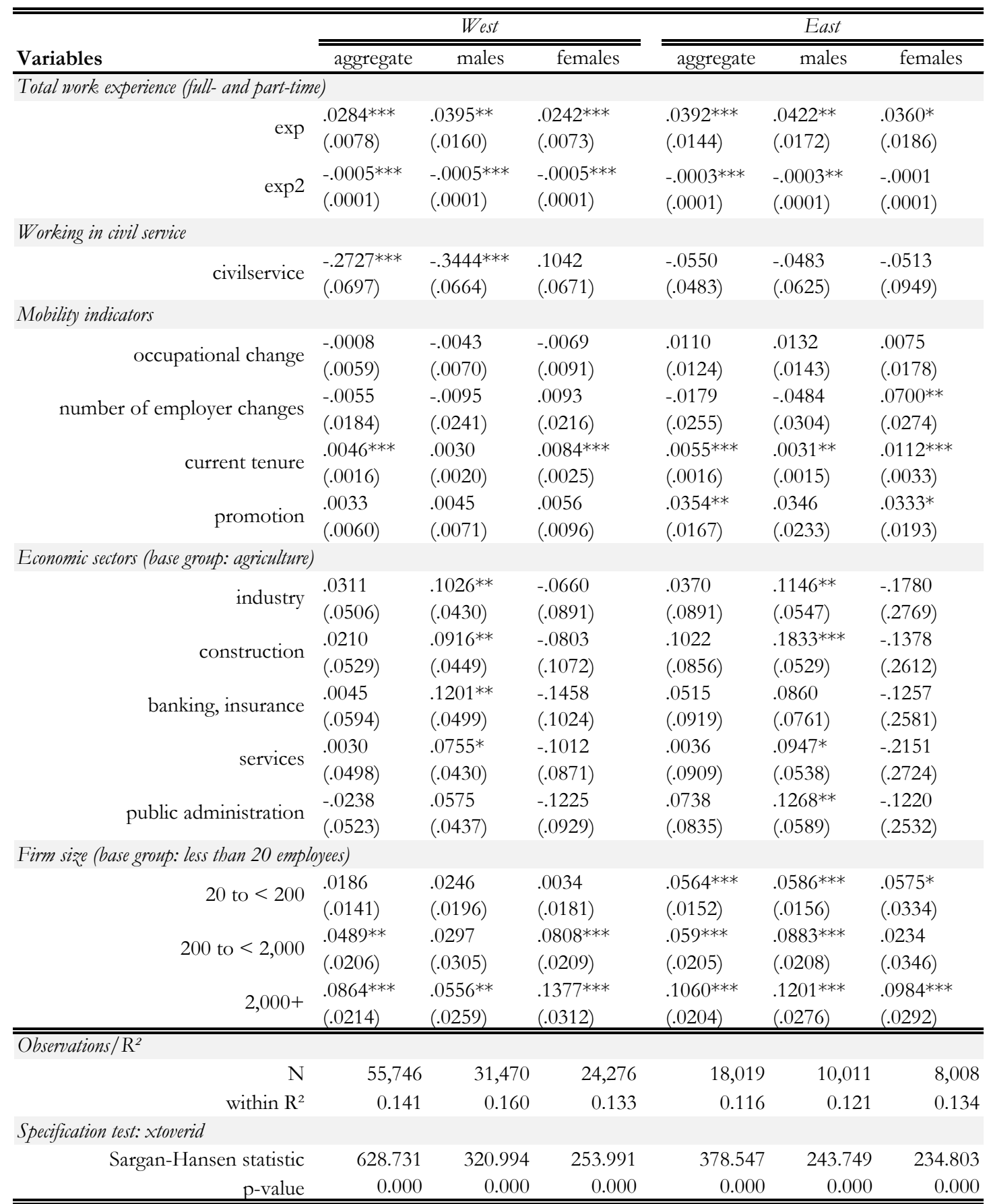

Note: (1) robust standard errors in parentheses (automatically computed and reported with p-weighted data), (2) longitudinal weighting factors were computed, (3) xtoverid is a generalized version of the Hausman test of fixed vs. random effects, (4) asterisks refer to significance levels: * 10 -percent, ${ }^{* *} 5$-percent, $* * * 1$-percent levels.

Source: Socio-economic Panel (SOEP) (2010), own calculations. 
TABLE A6 FIXED EFFECTS ESTIMATES OF COVARIATES, SAMPLE “ALL”

\begin{tabular}{|c|c|c|c|c|c|c|c|}
\hline \multirow{2}{*}{\multicolumn{2}{|c|}{ Variables }} & \multicolumn{3}{|c|}{ West } & \multicolumn{3}{|c|}{ East } \\
\hline & & aggregate & males & females & aggregate & males & females \\
\hline \multicolumn{8}{|c|}{ Total work experience (full- and part-time) } \\
\hline & $\exp$ & $\begin{array}{l}.0374 * * * \\
(.0079)\end{array}$ & $\begin{array}{l}.0411 * * \\
(.0160)\end{array}$ & $\begin{array}{l}.0361 * * * \\
(.0081)\end{array}$ & $\begin{array}{l}.0516^{* * *} \\
(.0138)\end{array}$ & $\begin{array}{l}.0574 * * * \\
(.0147)\end{array}$ & $\begin{array}{l}.0490 * * \\
(.0203)\end{array}$ \\
\hline & $\exp 2$ & $\begin{array}{l}-.0005^{* * *} \\
(.0001)\end{array}$ & $\begin{array}{l}-.0005^{* * *} \\
(.0001)\end{array}$ & $\begin{array}{l}-.0005^{* * *} \\
(.0001)\end{array}$ & $\begin{array}{l}-.0002^{* *} \\
(.0001)\end{array}$ & $\begin{array}{l}-.0003^{* *} \\
(.0001)\end{array}$ & $\begin{array}{l}-.0002^{*} \\
(.0001)\end{array}$ \\
\hline \multicolumn{8}{|c|}{ Working in civil service } \\
\hline & civilservice & $\begin{array}{l}-.2461 * * * \\
(.0768)\end{array}$ & $\begin{array}{l}-.3041 * * * \\
(.0773)\end{array}$ & $\begin{array}{l}.1024 \\
(.0642)\end{array}$ & $\begin{array}{l}-.0422 \\
(.0496)\end{array}$ & $\begin{array}{l}-.0250 \\
(.0600)\end{array}$ & $\begin{array}{l}-.0478 \\
(.0973)\end{array}$ \\
\hline \multicolumn{8}{|c|}{ Mobility indicator } \\
\hline & occupational change & $\begin{array}{l}-.0071 \\
(.0066)\end{array}$ & $\begin{array}{l}.0000 \\
(.0081)\end{array}$ & $\begin{array}{l}-.0153 \\
(.0103)\end{array}$ & $\begin{array}{l}.0078 \\
(.0131)\end{array}$ & $\begin{array}{l}.0132 \\
(.0159)\end{array}$ & $\begin{array}{l}.0019 \\
(.0203)\end{array}$ \\
\hline \multicolumn{8}{|c|}{ Economic sectors (base group: agriculture) } \\
\hline & industry & $\begin{array}{l}.1031^{*} \\
(.0540)\end{array}$ & $\begin{array}{l}.1642 * * \\
(.0654)\end{array}$ & $\begin{array}{l}.0241 \\
(.0799)\end{array}$ & $\begin{array}{l}.0450 \\
(.0861)\end{array}$ & $\begin{array}{l}.1245^{* *} \\
(.0568)\end{array}$ & $\begin{array}{l}-.1668 \\
(.2791)\end{array}$ \\
\hline & construction & $\begin{array}{l}.1135^{* *} \\
(.0540)\end{array}$ & $\begin{array}{l}.1859 * * * \\
(.0676)\end{array}$ & $\begin{array}{l}-.0279 \\
(.1017)\end{array}$ & $\begin{array}{l}.1003 \\
(.0834)\end{array}$ & $\begin{array}{l}.1949 * * * \\
(.0552)\end{array}$ & $\begin{array}{l}-.1837 \\
(.2646)\end{array}$ \\
\hline & banking, insurance & $\begin{array}{l}.2392^{*} \\
(.1379)\end{array}$ & $\begin{array}{l}.4050^{* *} \\
(.1855)\end{array}$ & $\begin{array}{l}-.0410 \\
(.0982)\end{array}$ & $\begin{array}{l}.0790 \\
(.0946)\end{array}$ & $\begin{array}{l}.1372 \\
(.0887)\end{array}$ & $\begin{array}{l}-.1164 \\
(.2639)\end{array}$ \\
\hline & services & $\begin{array}{l}.0731 \\
(.0555)\end{array}$ & $\begin{array}{l}.1470^{* *} \\
(.0639)\end{array}$ & $\begin{array}{l}-.0403 \\
(.0837)\end{array}$ & $\begin{array}{l}-.0011 \\
(.0886)\end{array}$ & $\begin{array}{l}.0865 \\
(.0572)\end{array}$ & $\begin{array}{l}-.2256 \\
(.2782)\end{array}$ \\
\hline & public administration & $\begin{array}{l}.0663 \\
(.0582)\end{array}$ & $\begin{array}{l}.1456^{* *} \\
(.0686)\end{array}$ & $\begin{array}{l}-.0498 \\
(.0861)\end{array}$ & $\begin{array}{l}.0647 \\
(.0832)\end{array}$ & $\begin{array}{l}.1002 \\
(.0636)\end{array}$ & $\begin{array}{l}-.1318 \\
(.2615)\end{array}$ \\
\hline \multicolumn{8}{|c|}{ Firm size (base group: less than 20 employees) } \\
\hline & 20 to $<200$ & $\begin{array}{l}.0373^{*} \\
(.0198)\end{array}$ & $\begin{array}{l}.0485^{* *} \\
(.0239)\end{array}$ & $\begin{array}{l}.0085 \\
(.0210)\end{array}$ & $\begin{array}{l}.0734 * * * \\
(.0178)\end{array}$ & $\begin{array}{l}.0730^{* * *} \\
(.0189)\end{array}$ & $\begin{array}{l}.0722 * * \\
(.0351)\end{array}$ \\
\hline & 200 to $<2,000$ & $\begin{array}{l}.0662^{* * * *} \\
(.0236)\end{array}$ & $\begin{array}{l}.0578^{*} \\
(.0325)\end{array}$ & $\begin{array}{l}.0768^{* * *} \\
(.0240)\end{array}$ & $\begin{array}{l}.0732 * * * \\
(.0203)\end{array}$ & $\begin{array}{l}.0956^{* * *} \\
(.0206)\end{array}$ & $\begin{array}{l}.0447 \\
(.0367)\end{array}$ \\
\hline & $2,000+$ & $\begin{array}{l}.1023 * * * \\
(.0241) \\
\end{array}$ & $\begin{array}{l}.0819 * * * \\
.0302) \\
\end{array}$ & $\begin{array}{l}.1359 * * * \\
(.0321) \\
\end{array}$ & $\begin{array}{l}.1262 * * * \\
.0207) \\
\end{array}$ & $\begin{array}{l}.1353^{* * *} \\
(.0275) \\
\end{array}$ & $\begin{array}{l}.1223 * * * \\
(.0318) \\
\end{array}$ \\
\hline \multicolumn{8}{|c|}{$\overline{\text { Observations } / \mathrm{R}^{2}}$} \\
\hline & $\mathrm{N}$ & 59,662 & 34,253 & 25,409 & 19,151 & 10,764 & 8,387 \\
\hline & within $\mathrm{R}^{2}$ & 0.131 & 0.157 & 0.121 & 0.082 & 0.086 & 0.109 \\
\hline \multicolumn{8}{|c|}{ Specification test: xtoverid } \\
\hline & $\begin{array}{r}\text { argan-Hansen statistic } \\
\text { p-value }\end{array}$ & $\begin{array}{r}687.331 \\
0.000\end{array}$ & $\begin{array}{r}388.169 \\
0.000\end{array}$ & $\begin{array}{r}273.005 \\
0.000\end{array}$ & $\begin{array}{r}401.590 \\
0.000\end{array}$ & $\begin{array}{r}251.862 \\
0.000\end{array}$ & $\begin{array}{r}265.088 \\
0.000\end{array}$ \\
\hline
\end{tabular}

Note: (1) robust standard errors in parentheses (automatically computed and reported with p-weighted data), (2) longitudinal weighting factors were computed, (3) xtoverid is a generalized version of the Hausman test of fixed vs. random effects, (4) asterisks refer to significance levels: $* 10$-percent, ${ }^{* *} 5$-percent, $* * * 1$-percent levels. Source: Socio-economic Panel (SOEP) (2010), own calculations. 
TABLE A7 FIXED EFFECTS ESTIMATES OF COVARIATES, SAMPLE "SELF"

\begin{tabular}{|c|c|}
\hline Variables & Germany \\
\hline \multicolumn{2}{|l|}{ Total work experience (full- and part-time) } \\
\hline $\exp$ & $\begin{array}{l}-.0125 \\
(.0437)\end{array}$ \\
\hline $\exp 2$ & $\begin{array}{l}-.0001 \\
(.0002)\end{array}$ \\
\hline \multicolumn{2}{|l|}{ Mobility indicator } \\
\hline occupational change & $\begin{array}{c}.0269 \\
(.0395)\end{array}$ \\
\hline \multicolumn{2}{|l|}{ Economic sectors (base group: agriculture) } \\
\hline industry & $\begin{array}{l}-.0055 \\
(.0865)\end{array}$ \\
\hline construction & $\begin{array}{l}-.0361 \\
(.0910)\end{array}$ \\
\hline banking, insurance & $\begin{array}{l}.0619 \\
(.1392)\end{array}$ \\
\hline services & $\begin{array}{l}-.1259 \\
(.0765)\end{array}$ \\
\hline public administration & $\begin{array}{l}-.0393 \\
(.0983)\end{array}$ \\
\hline \multicolumn{2}{|c|}{ Firm size (base group: less than 20 employees) } \\
\hline 20 to $<200$ & $\begin{array}{c}.3719^{* * *} \\
(.1421)\end{array}$ \\
\hline 200 to $<2,000$ & $\begin{array}{c}.0024 \\
(.0602)\end{array}$ \\
\hline $2,000+$ & $\begin{array}{l}-.0664 \\
(.1560) \\
\end{array}$ \\
\hline \multicolumn{2}{|l|}{ Observations/ $\mathrm{R}^{2}$} \\
\hline $\mathrm{N}$ & 4,575 \\
\hline within $\mathrm{R}^{2}$ & 0.042 \\
\hline \multicolumn{2}{|l|}{ Specification test: xtoverid } \\
\hline $\begin{array}{r}\text { Sargan-Hansen statistic } \\
\text { p-value }\end{array}$ & $\begin{array}{r}126.853 \\
0.000 \\
\end{array}$ \\
\hline
\end{tabular}

Note: (1) robust standard errors in parentheses (automatically computed and reported with p-weighted data), (2) longitudinal weighting factors were computed, (3) xtoverid is a generalized version of the Hausman test of fixed vs. random effects, (4) asterisks refer to significance levels: * 10-percent, ** 5percent, *** 1-percent levels.

Source: Socio-economic Panel (SOEP) (2010), own calculations. 


\section{CONCLUSION}

\section{Summary}

This thesis provides three applied contributions to the field of the economics and econometrics of education. The empirical analyses are all based on data from the German Socio-Economic Panel (SOEP) and evaluate the returns to various qualifications in Germany. The papers differ in content and methodology. However, they all attempt to establish a closer link between the empirical evaluation of specific qualifications and the underlying educational subsystems which provide these qualifications. Important aspects and particularities of the German educational system, especially the track nature of school and post-school qualifications in association with the impact of family background on schooling outcomes and the ongoing debate with respect to the effectiveness of the apprenticeship system, the most important provider of post-school qualifications, build the framework of analysis and provide additional perspectives with regard to the interpretation of the return estimates and their policy implications.

The first paper is an introductory and very compressed paper with some focus on the apprenticeship system. Methodologically, its contribution lays in the specification of the education variables, in particular the differentiation of vocational qualifications with respect to secondary school type and training sector as well as the separation of apprenticeships and fulltime vocational schooling both of which provide initial vocational education.

The returns to vocational education, both initial and further, differ considerably with secondary school type. The return to vocational education conditional on the lowest level of schooling is up to about 25 percentage points below the return conditional on the highest level of secondary school type. Though there is some decline in the returns to all levels of qualification over time, this drop is most pronounced for those with the lowest level of qualification, i.e. the combination of lower secondary schooling and initial vocational education. Finally, the return to craft-specific apprenticeships is below the return to other apprenticeships in all years. This is also true for the return to craft-specific further vocational education, except in 2005.

The second paper focuses on the consequences of children's early streaming into secondary school tracks as well as the influence of parental background and individual ability on school and post-school educational outcomes on the one hand and on labor market outcomes (labor earnings) on the other hand. The discussion suggests an incorporation of these aspects into the wage equation framework by comprehensively controlling for the endogeneity of education. The 
analysis is novel in three respects. For the first time, a German application directly accounts for family background and cognitive ability at the same time. Moreover, the paper uses very novel cognitive ability measures which have been introduced to the SOEP only recently and have not been used in an analysis of the returns to qualifications before. Finally, the analysis accounts for observable heterogeneity in the return estimates.

A positive and non-negligible family background and ability bias can be detected with respect to all types of post-school qualifications. However, once school qualifications are controlled for, this bias is considerably reduced. Moreover, there is an unexpected negative bias associated with the variable high school.

Overall, the post-school qualification estimates react more strongly to the inclusion of school qualifications than to the inclusion of the sets of cognitive ability and family background measures. However, academic qualifications react much more strongly to their inclusion than initial and further vocational qualifications, which is not too surprising given the strong interdependence between the two. School qualifications are themselves significant and important in size. Also, they by far exceed the return associated with apprenticeship training. However, the differences in the returns to school qualifications show that higher level school qualifications are the most important drivers of the returns to complete educational paths.

As regards the cognitive ability measures, only two of them have a statistically significant impact. Their direct impact is very moderate in size. The learning capacity and stock of knowledge measure (WFT) positively affects wages, while the school grade item non-response indicator is negative. Contrary to what was suggested in the discussion, the cognitive ability measure which indicates learning efficiency and information processing capabilities (SCT) has no significant impact.

Finally, the second paper analyzes linear and non-linear aspects of heterogeneity in the returns to qualifications with respect to cognitive ability. Interaction effects between the type of school qualification and the average grade are significant for high school graduates only. However, the estimate associated with being in the top 25 per cent of the high school grade distribution is double the estimate associated with being in the bottom 25 per cent. The findings with respect to the cognitive ability tests are somewhat unexpected. The main effect of the learning capacity indicator (WFT) rises if the linear interaction terms are included. These suggest however that learning capacity does not have a positive impact across all types of qualifications. Moreover, accounting for non-linearities turns the learning efficiency indicator (SCT) positive and significant. However, being in the top 25 per cent of either test distribution is associated with a negative wage premium for higher level school leavers. In contrast, being in the bottom 25 per 
cent of either test distribution is associated with a positive premium for some post-school qualifications.

The third paper focuses on sequences of post-school qualifications and specifically looks at post-apprenticeship investments in education both at the vocational and academic levels. Again, the starting point is the apprenticeship system. However, in contrast to the first paper, the analysis goes further and analyzes in how far the structural change in the economy and changing individual preferences may have resulted in the diverging patterns of apprenticeships and related further educational options. The returns to these further educational options are then evaluated. The main contribution of the paper is that it uses longitudinal data and provides fixed-effects estimates of post-apprenticeship formal qualifications at the vocational and academic levels. Thus the analysis accounts for unobservable time-constant individual heterogeneity.

A first descriptive analysis of the role of sequences of post-school qualifications shows that postapprenticeship investments in further vocational and academic education are important. Already, academic education has a slightly higher weight than further vocational education and it can be expected that post-apprenticeship academic education is going to gain further weight relative to further vocational education in the future. This expectation is based on observations regarding the structural change the apprenticeship system has undergone during the last decades and how further educational options have evolved accordingly. Further evidence suggested that traditional craft and industry apprenticeships and corresponding further vocational qualifications are on a decline. In contrast, commercial and service-related apprenticeships gain importance and corresponding further education options often are pursued at the academic level. Overall, the empirical analysis supports these observations. The return to post-apprenticeship further vocational education is not statistically significant in most specifications. Thus the additional investment did not pay off. In contrast, the positive return to academic education is highly statistically significant and sizeable, except for the sample which restricts the analysis to the selfemployed. Entrepreneurial success is thus not a linear function of the level of education. Combining further vocational and academic education is associated with a strong wage penalty. The job classification analysis of the SOEP sample with regard to the current job individuals had at the time they completed their post-apprenticeship further education provides some further insights. In fact, craft and industry specific occupations at the basic and intermediate level dominate among those with further vocational education, while these occupations play only a minor role for individuals with mixed vocational and academic paths. Here, managing, commercial and service-related occupations dominate. However, high-skill technical occupations 
are important as well. Therefore, while purely vocational paths in technical occupations may no longer be economically profitable, mixed vocational plus academic paths are.

\section{Discussion and implications}

This dissertation set out to further the academic and political discussions on the effective provision of education in an increasingly older and unequal society whose future economic competiveness is mainly driven by the quality of its human capital. Moreover, based on the conviction that the German economy can no longer afford to let education potentials go unexploited or to spend resources on human capital investments which are not economically and/or socially beneficial, the papers focused on two specific aspects of the education system which are on the current political agenda: the perceived unequal access to education and resulting path dependencies in terms of the heterogeneity of post-school qualifications, in particular vocational vs. academic. Before these issues are discussed against the background of this work's findings as well as in the light of recent educational policy and reform initiatives, some general remarks on the importance of the concept of the return to education are in order, in particular with regard to its potential for policy recommendations.

In academia the dispute over whether education is a private or a public good, a mixed or a merit good remains unsolved. Moreover, according to Timmermann (2005, pp. 82) ${ }^{98}$ there is disagreement over whether education is associated with positive externalities. However, in Germany education is state-provided and treated as a non-private good. Thus, politically, state intervention in educational matters is justified. Apart from some minor privatization tendencies, the German states are the sole providers of school education in Germany. In contrast, the apprenticeship system is a three-tiered system with responsibilities taken on by the public sector, the chamber organizations and private firms.

Clearly, since education involves the allocation and the use of resources, education necessarily is an economic good (Timmermann, 2005, p. 82). It is also generally acknowledged that education exhibits characteristics of an investment good, with resources spent today and the expectation of benefits tomorrow. Therefore, the educational system is responsible for supplying the economy with skilled labor. The skills and competencies demanded in many occupations have been upgraded due to technological change and the introduction of IT and the educational institutions are under constant pressure to adjust accordingly. Moreover, based on equity considerations and

\footnotetext{
${ }_{98}$ Timmermann, D. (2005), Bildungsökonomie, in: Tippelt, R. (ed.), Handbuch Bildungsforschung, Wiesbaden, pp. 81 122.
} 
the principle of equality of opportunity, education is a direct means to facilitate social and income mobility.

As a consequence, education should be subject to evaluation based not only on criteria such as efficiency, effectiveness and profitability, but also distributional justice. The return to education is an important economic and direct indicator of the profitability of educational investments in terms of their labor market potential, i.e. the impact of such investment on labor income. Also, if the labor market returns of educational programs indicate the productivity increase in individuals' current job due to the investment, it sheds light on the effectiveness of the investment. Moreover, given certain path dependencies and the determinants of educational outcomes, the heterogeneity in the returns to specific qualifications may serve as an indirect measure of distributional justice.

In fact, there has been a surge in educational evaluation studies, international and national, during the last decade. Politically, the German government has come under considerable pressure after the publication of the first Program for Student Assessment (PISA) results in 2001. The Program evaluates literacy competencies of 15 year old students in reading, mathematics and science. Apart from the fact that the German students performed comparatively weak in the tests, researchers found that the correlation between family background and students' performance is strongest in Germany. In part, these observations were ascribed to the track nature of the German educational system, in particular the three-tiered school system. The latest PISA results suggest, that the association between family background and educational outcomes has declined, but nonetheless remains comparatively strong.

This thesis took up this critique and discussed the influence of family background as well as the impact of the track nature of the school system on school and post-school educational outcomes as well as labor market outcomes. Against this background, it was suggested to estimate the returns to vocational qualifications conditional on secondary school type (paper 1) and to completely separate school and post-school qualifications in order to estimate their return rates separately (paper 2). Moreover, the direct inclusion of family background indicators in the estimations (paper 2) showed how the returns to qualifications were affected by them.

It is a good sign that the returns to all school and post-school qualifications are positive and significant, even if account is taken of differences in cognitive ability and family background. Thus, education generally does make a difference. However, the returns to school qualifications are quite heterogeneous. Moreover, the returns to complete educational paths, i.e. school and post-school qualification, are largely determined by the return to secondary school type. Given 
that the choice of post-school qualifications is determined by the type of secondary school and the resulting existence of path dependencies in the educational system, it seems that the German educational system manifests the existing social differences rather than contributes to balancing them and to raising social mobility.

A recent school reform initiative in the state of Hamburg, which particularly aimed at delaying the early streaming into secondary school tracks, was largely rejected in a referendum. The referendum was enforced by a parent initiative, mainly supported by people with privileged background. In contrast, the Federal Ministry of Labor and Social Affairs recently has initiated "the educational package" targeting young and school children in low income families. The package entails a variety of measures to increase equality of opportunity mainly with respect to the access to education such as learning support, learning materials or cultural activities. The benefits have to be applied for and it may be for this reason that the general reception is very low. Overall, better knowledge about the association between individuals' education and their labor market potential and, more importantly, direct evidence of the heterogeneity in the returns to both school and post-school qualifications, may help to raise people's and, most importantly, parents' awareness of the flaws of the established structure of the educational system. This seems even more pressing given the tendencies toward paid (extracurricular) educational courses in child daycare centers.

Furthermore, the thesis suggested that the streaming into secondary school tracks determines the choice of post-school qualifications. It was shown that this choice is highest for high school graduates, since they have access to all types of post-school qualifications. Lower secondary and intermediate secondary school leavers do not have direct access to higher education. They are forced to enter the system of initial vocational education, i.e. apprenticeship training or full-time vocational schooling. Further vocational tracks may be entered conditional on the successful completion of initial training. Recently though, access to higher education institutions has been facilitated for those with further vocational education.

The cross-sectional analyses in papers 1 and 2 suggested a significantly positive and sizeable return to further vocational education relative to having no post-school qualification, even conditional on secondary school type. However, based on the above considerations and the fact that post-apprenticeship investments in further vocational education have declined (in the craft sector), while post-apprenticeship investments in higher education have increased (in banking) over time, it was suggested to estimate the incremental return to further vocational and academic education among those with initial vocational education in a longitudinal setting (paper 3). The 
fixed-effects estimates of the returns to post-initial further vocational education were insignificant in most specifications, while the returns to academic education were significant and substantial. Moreover, investments in both further vocational and academic education are associated with a significant wage penalty. In principle, only the fixed-effects estimates allow a causal interpretation of the return estimates. However, the panel analysis may be less representative of the total population.

The findings suggest further systematic research with respect to the direct returns to post-initial investments in further vocational vs. academic education. In fact, if purely vocational paths, in particular the second higher level investment, deliver no positive return, the consequences are large - economically, socially and politically. Recent educational policy has extended financial support for individuals who opt for further vocational tracks. Moreover, the craft sector is legally built on and largely dependent upon purely vocational paths. In addition, further vocational education is the path to further attainment and expected advancement for lower and middle level school leavers. Evidence showed that the attractiveness of this path has already declined. If further vocational education is not economically reasonable, this will have repercussions on the corresponding initial training options. Only imagine a savings account which gives you no return whatsoever. Socially and politically, this finding seriously questions the heading of the federal government's qualification initiative "advancement through education" for individuals with intermediate school and post-school qualifications, i.e. the majority of the German population.

Overall, I very much agree with economist Alfred Marshall" who once said that "[t]he most valuable of all capital is that invested in human beings". Yet, the findings of this thesis suggest that these investments have to be very wisely considered and that their value very much depends on the type of investment. Moreover, given that the investments themselves require the spending of valuable resources, public and private, financial and other, and given that the returns to these investments are so heterogeneous in terms of their labor market value, they require constant and very careful evaluation. This thesis makes a small though very committed contribution in this respect.

${ }^{99}$ Cited in: Wößmann, L. (2003), Specifying human capital, Journal of Economic Surveys, 17(3), pp. 239-270. 